\title{
EFEITOS DE SISTEMAS DE PREPARO DO SOLO NA CULTURA DA SOJA [Glycine max (L.) MERRIL] EM SOLOS DE CERRADOS
}

\author{
JOSÉ FREDERICO CENTURION
}

Engenheiro Agrônomo

Orientador: JOSÉ LUIZ IORIATTI DEMATTÊ

Dissertação apresentada à Escola Superior de Agricultura "Luiz de Queiroz", da Universidade de São Paulo, para obtenção do título de Mestre em Agronomia - Área de Concentração: Solos e Nutrição de Plantas.

PIRACICABA

Estado de São Paulo - Brasil

Fevereiro - 1984 
. ii.

Aos meus pais

Francisco e Victória,

OFEREÇO.

à minha esposa Cidinha,

DEDICO . 


\section{AGRADEC IMENTOS}

À Universidade Estadual Paulista - "Campus" de Ilha Solteira, à Escola Superior de Agricultura "Luiz de Queiroz" e ao convênio CAPES/PICD/UNESP, pela oportunidade proporcionada pela realização do curso de Mestrado.

Ao Prof. Dr. José Luiz Ioriatti Demattê, o nosso sincero reconhecimento pela dedicação, interesse e segura 으 rientação em todas as fases do presente trabalho.

Ao Prof. Dr. Rubens Scardua, pelas facilidades concedidas para a realização das análises físico-hídricas.

À Engạ Agrạ, MS, Maria Aparecida Anselmo Tarcitano, pelo auxillio prestado por ocasião da realização das aná lises referentes à viabilidade econômica.

Ao Prof. Dr. Paulo L. Libardi, pela confecção do Summary

A todos que de alguma forma contribuiram para a realização deste trabalho. 


\section{ÍNDICE}

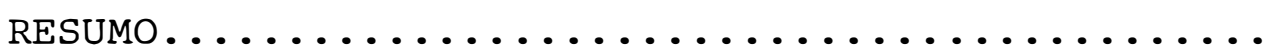

vii

SUMMARY.

1. INTRODUÇÃO.

2. REVISÃO DE LITERATURA ..................

2.1. Características químicas do solo em rela-

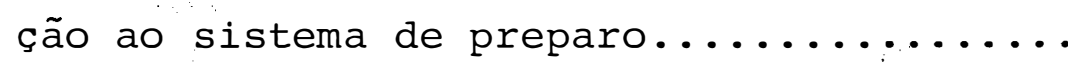

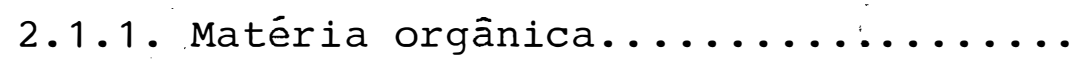

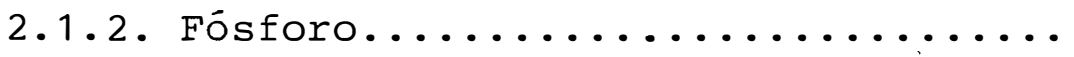

2.1.3. Acidez, cálcio e magnésio.........

2.1.4. Potássio, alumínio e capacidade de troca catiônia (CTC) ............

2.2. Teores de nutrientes do tecido vegetal em

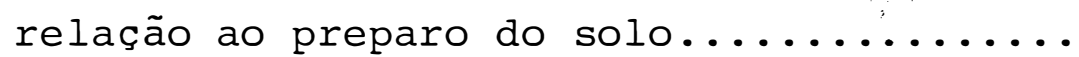

2.3. Caracteristicas físicas do solo em relação

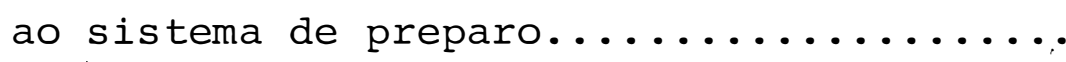

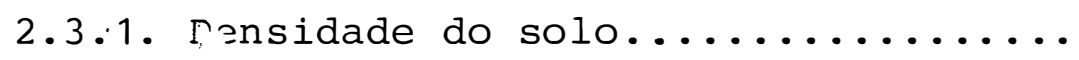

2.3.2. Porosidade total, macro e microporo

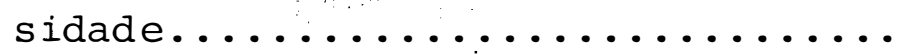

2.3.3. Resistēncia do solo à penetração...

2.3.4. Infiltração e retenção de água.....

2.4. Características agronômicas em relação ao

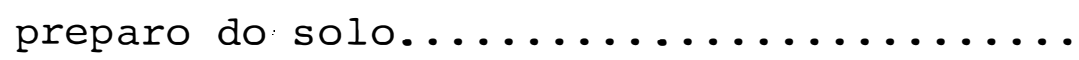


2.4.1. "Stand"..................

2.4.2. Alturas da planta e da inserção

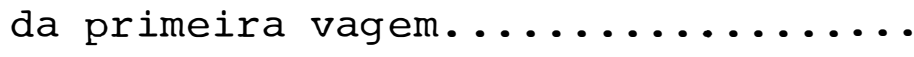

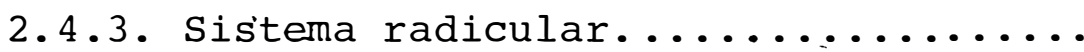

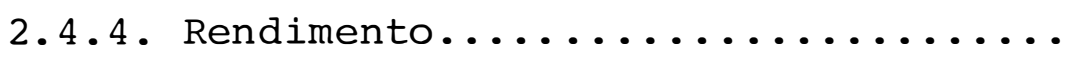

2.5. Viabilidade econômica................. 20

3. MATERIAL E MÉTOLOS......................... 22

3.1. Localização e descrição da área experimen-

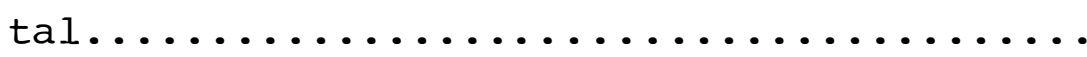

3.2. Adequação da área e tratamentos..........

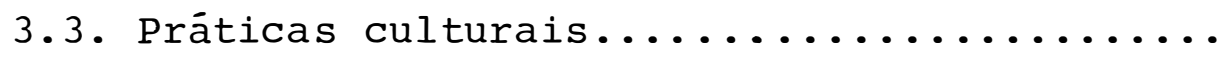

3.3.1. Semeadura...................

3.3.2. Controle de ervas daninhas.........

3.3.3. Adubação.

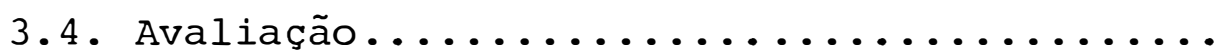

3.4.1. Análises químicas do solo e do teci-

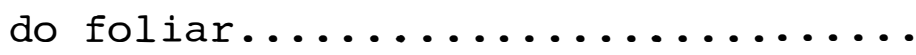

3.4.2. Anális is físicas do solo..........

3.4.3. Caracteristicas agronômicas........

3.4.4. Viabilidade econômica............

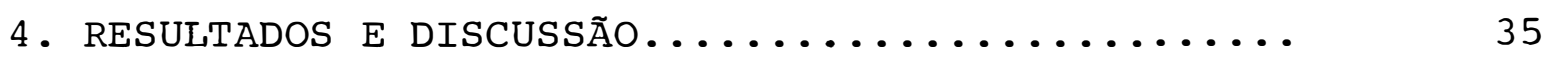

4.1. Caracteristicas químicas do solo.......... 35

4.2. Análise do tecido foliar............... 47

4.3. Características físicas do solo.......... 50 
4.4. Características agronōmicas..............

4.5. Viabilidade econōmica................

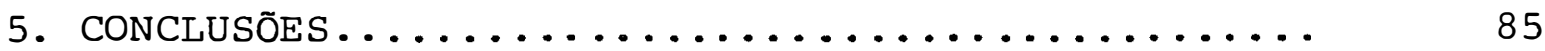

6. LITERATURA CITADA..................... 88

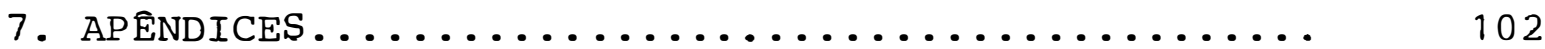




\section{LISTA DE TABELAS}

Tabela

Página

1 Principais caracteristicas quimicas e granulométricas do Latossol Vermelho Escuro estudado, por ocasião do desmatamento da â

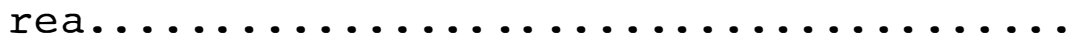

2 Discriminação das operações para cada tratamento nos anos agrícolas 1981/82 e 1982/

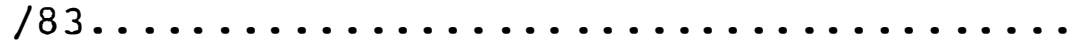

3 Efeito dos sistemas de preparo do solo nos teores e distribuição de cobre, ferroe zin co, obtidos de amostras de solo coletadas antes da semeadura da soja do ano agrícola

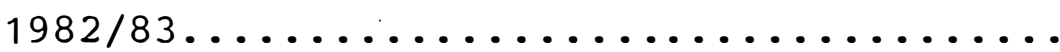

4 Valores de nitrogênio, fósforo, potássio, cálcio e magnésio do tecido foliar da soja, expressos em \%, referentes aos tratamentos utilizados no ano agrícola 1981/82.

5 Valores de nitrogênio, fósforo, potássio, cálcio'e magnésio do tecido foliar da soja, expressos em $\%$, referentes aos tratamentos utilizados no ano agrícola 1982/83.

6 Valores médios de densidade do solo $\left(\mathrm{g} \cdot \mathrm{cm}^{-3}\right)$ e resistência à penetração $\left(\mathrm{kg} / \mathrm{cm}^{2}\right)$, a várias profundidades em relação a métodos de preparo, nos anos agrícolas 1981/82 e

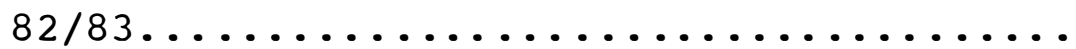


7 Efeitos de sistemas de preparo do solo e modos de adubação em algumas características agronômicas da soja, no ano agríco

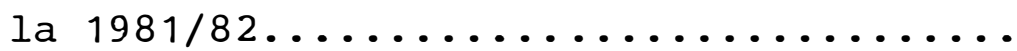

8 Efeitos de sistemas de preparo do solo e modos de adubação em algumas características agronômicas da soja, no ano agríco la $1982 / 83 \ldots \ldots \ldots \ldots \ldots \ldots \ldots \ldots$

9 Comparação de médias de "stand" da soja (no de plantas/m) nos diversos sistemas de preparo de solo dentro dos diferentes modos de adubação, pelo teste de Tukey a 5\% de probabilidade no ano agrícola 1982/

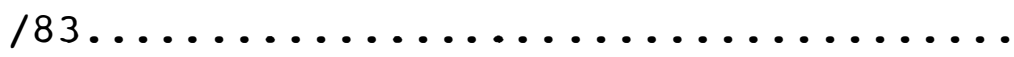

10 Comparação de média de altura da planta de soja (cm) nos diversos sistemas de preparo de solo dentro dos diferentes mo dos de adubação, pelo teste de Tukey a 5\% de probabilidade, no ano agrícola $1982 / 83 \ldots \ldots \ldots \ldots \ldots \ldots \ldots \ldots \ldots \ldots \ldots$

11 Comparação de médias de altura de inser ção da 1ạ vagem de soja (cm) nos diversos sistemas de preparo de solo dentro dos diferentes modos de adubação, pelo teste de Tukey a 5\% de probabilidade no ano agrícola 1982/83............... 
12 Comparação de médias de altura da planta de soja (cm) dos diferentes modos de adubạção dentro do sistema de preparo reduzido do so 1o. pelo teste de Tukey a 5\% de probabilidas

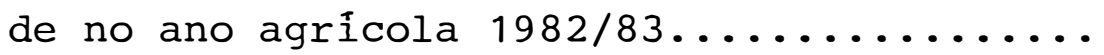

13 Comparação de médias de rendimentos de grãos de soja (kg/ha) nos diversos sistemas de preparo de solo dentro dos diferentes mo dos de adubação, pelo teste de Tukey a 5\% de probabilidade nos anos agrícolas de:1981/

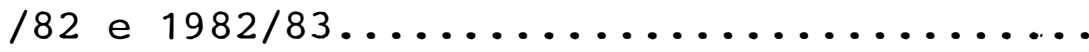

14 Comparação de médias de peso de 100 grãos de soja (g) nos diversos sistemas de preparo do solo dentro dos diferentes modos de adubação, pelo teste de Tukey a 5\% de probabilidade, nos anos agrícolas 1981/82 e 82/83.

15 Efeito do preparo do solo e modo de aplicação de fertilizantes na distribuição do sis tema radicular da soja, expresso em gramas de peso seco/planta, no ano agrícola 1982/

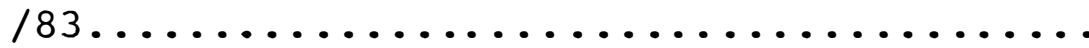

16 Efeito do preparo do solo e modo de aplicação de fertilizantes na distribuição do sis tema radicular da soja, expresso em porcentagem de peso seco/planta, no ano agrícola

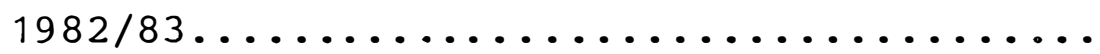


17 Estimativas dos custos e taxas residuais da exploração de soja, referentes aos trạ tamentos utilizados no ano agrícola 1981/

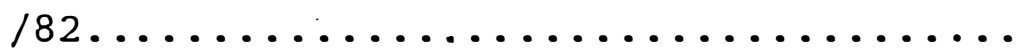

18 Estimativas dos custos operacionais e ta xas residuais da exploração de soja, referentes aos tratamentos utilizados no a no agrícola 1982/83............... 


\section{LISTA DE FIGURAS}

1 Valores médios de matéria orgânica (\%), oḅ tidos em diferentes profundidades do solo, referentes aos diversos tratamentos estuda dos nos anos agricolas 1981/82 e 1982/83..

2 Valores médios de fósforo solūvel (ppm), obtidos em diferentes profundidades do solo, referentes aos diversos tratamentos estuda dos nos anos agrícolas 1981/82 e 1982/83..

Valores médios de potássio trocável (ppm), obtidos em diferentes profundidades do so1o, referentes aos diversos tratamentos es tudados nos anos agrícolas 1981/82 e 82/83

4 Valores médios de cálcio + magnésio trocável (e.mg/100 ml de TFSA), obtidos em dife rentes profundidades do solo, referentes aos diversos tratamentos estudados nos anos agrícolas 1981/82 e 82/83..........

5 Valores médios äe $\mathrm{pH}$ em $\mathrm{H}_{2} \mathrm{O}$, obtidos em dí ferentes profundidades do solo, referentes aos diversos tratamentos estudados nos anos agrícolas 1981/82 e 1982/83........

Valores médios de C.T.C. ao pH 7,0 (e.mg / $100 \mathrm{ml}$ de TFSA), obtidos em diferentes pro fundidades do solo, referentes aos diver sos tratamentos estudados nos anos agríco- 
Valores médios de C.T.C. ao pH 7,0 (e.mg./ $100 \mathrm{ml}$ de TFSA), obtidos em diferentes pró fundidades do solo, referentes aos diversos tratamentos estudados nos anos agrícolas $1981 / 82$ e $1982 / 83 \ldots \ldots \ldots \ldots \ldots \ldots \ldots$

7 Valores médios de saturação de alumínio (\%), obtidos em diferentes profundidades do so10, referentes aos diversos tratamentos es tudados nos anos agrícolas 1981/82 e 1982/

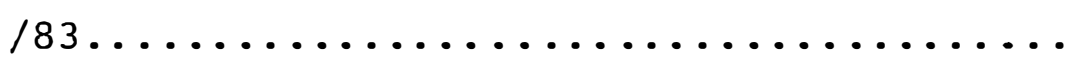

8 Valores de macroporosidade, microporosidade e porosidade total avaliada, obtidos em função do preparo do solo, no ano agrícola

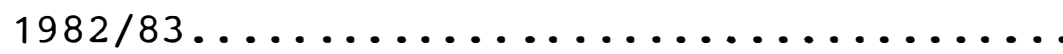

9 Valores de infiltração acumulada de água , para os diversos sistemas de preparo do so 10, obtidos nos anos agrícolas 1981/82 e

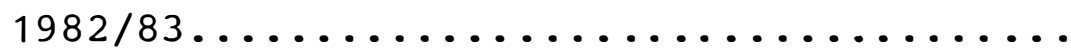

10 Valores de velocidade de infiltração de água para os diversos sistemais de preparo, obtidos nos anos agrícolas 1981/82 e 1982/

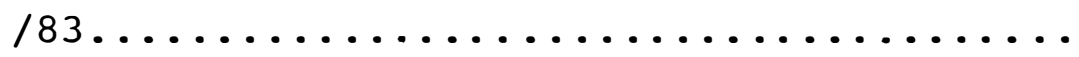

11 Curvas de retenção de umidade obtidas na profundidade de 0 a $3 \mathrm{~cm}$, para os diversos sistemas de preparo do solo estudados no a no agricola $1982 / 83 \ldots \ldots \ldots \ldots \ldots \ldots \ldots \ldots \ldots \ldots$ 
13 Curvas de retenção de umidade obtidas na profundidade de 20 a $23 \mathrm{~cm}$, para os diversos sistemas de preparo do solo estudados no ano agrícola 1982/83.........

14 Curvas de retenção de umidade obtidas na profundidade de 40 a $43 \mathrm{~cm}$ para os diver sos sistemas de preparo do solo estuda dos no ano agrícola 1982/83..........

15 Curvas de retenção de umidade obtidas na profundidade de 60 a $63 \mathrm{~cm}$, para os diversos sistemas de preparo do solo estudados no ano agrícola 1982/83.........

16 Valores de precipitação e umidade do solo, para as profundidade de 20 a $23 \mathrm{~cm}$, 40 a $43 \mathrm{~cm}$ e 60 a $63 \mathrm{~cm}$, obtidos durante o ciclo da soja, cultivada no ano agrícola 1982/83................ 


\section{EFEITOS DE SISTEMAS DE PREPARO DO SOLO NA CULTURA DA SOJA [Glycine max (L.) MERRIL] EM SOLO DE CERRADO}

JOSÉ FREDERICO CENTURION

- Orientador -

JOSÉ LUIZ IORIATTI DEMATTÊ

\section{RESUMO}

O principal objetivo pretendido neste trabalho foi o de avaliar os efeitos de sistemas de preparo do solo e modos de aplicação de adubos (correção e parcelado) na cultura da soja em dois anos agricolas (81/82 e 82/83) no municipio de Selviria, Estado do Mato Grosso do Sul. A vegetação natural é de cerrado e o solo trabalhado, um Latossol Vermelho Escuro a giloso, álico (Acrustox). A área é caracterizada por um clima do tipo Aw com temperatura média anual de $23,6^{\circ} \mathrm{C}$, precipitação de $1330 \mathrm{~mm}$ e uma evapotranspiração potencial de $1226 \mathrm{~mm}$. O déficit hídrico é em torno de $74 \mathrm{~mm}$.

Além do sistema convencional de preparo do solo testaram-se os sistemas reduzido superpreparo e semeadura direta. Aliado a tais sistemas testou-se a adubação de correção to 
tal e a parcelada, completando com análises econômicas.

$$
\text { Utilizaram-se diversos parânetros de medidas tan- }
$$

to do solo (determinações físicaś e quỉmicas) como da planta (caracteristicas agronômicas).

De maneira geral, o sistema de semeadura direta proporcionou um melhor rendimento de grãos, tornundo-o economicamente mais viável; além disso,os modos de aplicação de adubos não afetaram significativamente o rendimento de grãos. Com exceção da semeadura direta,os demais sistemas de preparo induziram a formação de camadas compactadas, o que ocasionou me nor taxa de infiltração de água e maior frequência de desvios do sistema radicular da sojá. 


\section{EFFECTS OF SOIL PREPARATION SYSTEMS IN A \\ "CERRADO" SOIL CROPPED WITH \\ SOYBEAN [Glycine max (L.) MERRIL]}

JOSÉ FREDERI CO CENTURION

( AUTHOR)

JOSÉ LUIZ IORIATTI DEMATTÊ

(ADVISER)

\section{SUMMARY}

The main objective of this work was to evaluate effects of soil preparation systems and of fertilizer application wyas on soybean crop in two agricultural years $(1981 / 1982$ and 1982/1983), in the county of Selviria, Mato Grosso do sul (Brazil). The natural vegetation of the area is "cerrado" and the soil a dark red latosol (Acrustox). The climate of the region is of the type Aw; the mean annual temperature is $23.6^{\circ} \mathrm{C}$, the meain annual precipitation is $1,330 \mathrm{~mm}$ and the mean annual potential evapotranspiration is 1,226 mm. There is a hydric deficit of about $74 \mathrm{~mm}$.

The experiment design consisted of three soil preparation systems (reduced, maximum and no-tillage) and two fertilizer application ways (of correction and split). Economical analyses were also done at the end of the experiment. 
Several measurement parameters were utilized both for soil (physical and chemical determination) and plant (agriculture characteristics).

In general the no-tillage system showed a better grain yield, becoming viable economically. The fertilizer application ways did not effect significantly the grain yield. Excepting the no-tillage system, the other preparation systems induced the formation of compact layers, giving rise to a lesser water infiltration rate and higher deviation frequencies of the soybean root system. 


\section{INTRODUÇÃO}

Com a expansão de novas fronteiras agrícolas, os solos sob vegetação de cerrados estão sendo rapidamente incorporados ao processo produtivo do País.

Estima-se que, de uma área de 180 milhões de hec tares em cerrados, cerca de 50 milhões sejam de terras aráveis e potencialmente aptas para várias culturas, dentre elas, a da soja (EMBRAPA/CPAC, 1976). Esta cultura com variedades de ciclos curtos (80 dias) e ciclos longos (180 dias) encaixa-se perfeitamente nas condições de precipitação pluviométrica da região dos cerrados (PEREIRA, 1981).

Grande parte cesta área, cerca de 56\%, são ocupados pelos Latossóis (EMBRAPA/CPAC, 1976) -solos profundos, de textura variável, quase sempre média a argilosa, de relevos planos e suavemente ondulados, de baixa fertilidade natural e baixa retenção de água. 
Como a expansão das culturas de grãos tem. sido feita também nestas regiões, é imperativo que haja investigação nas mais diversas áreas de agronomia. O Centro de Pesquisa Agropecuária dos Cerrados (CPAC), localizado em Brasillia, assim como outros órgãos da Empresa Brasileira de Pesquisa Agropecuá ria (EMBRAPA), entre eles o Centro Nacional de Pesquisa do Arroz e Feijão (CNPAF) em Goiânia, têm-se dedicado às mais diversas áreas de pesquisa. Entretanto os dados, apesar da excelência de qualidade, aindá são poucos e de representatividade reduzida. Além disso,o plantio direto em soja é largamente difundido no sul do Paîs (Estado do Paraná), cujo apoio de pesqui sa é dado pelo Instj.tuto Agronômico do Paraná (IAPAR).

Com a finalidade de contribuir ainda mais para o manejo de tais solos é que foi conduzida esta pesquisa. Os prin cipais objetivos aqui pretendidos são os de estudar os efeitos do preparo de solo e moáos de aplicação de adubos na cultura da soja, no município de Selvíria, Estado de Mato Grosso do Sul. 


\section{REVISÃO DE LITERATURA}

Entre os sistemas de preparo do solo, o maís $\underline{\mathrm{u}}$ tilizado é o chamado convencional, que consiste na aração e gradeação da terra, quantas vezes forem necessárias para deixá-la em boas condições de receber a semente.

Nos últimos anos novas técnicas de preparo do solo estão sendo experimentadas no Brasil, baseadas em resultą dos obtidos nos Estados Unidos e Europa, entre elas o sistema de preparo reduzido. Este sistema, segundo RAMOS (1974), compreen de a semeadura de uma determinada cultura com movimentação reduzida do solo. Há várias formas de preparo reduzido de solo, de acordo com a intensidade de movimentação, destacando-se o sistema de semeadura com nenhum preparo (plantio direto), ou seja, as sementes e os fertilizantes são colocados no solo com o mínimo de movimentação do solo. 


\subsection{Caracteristicas quimicas do solo em relação ao sistema. de preparo}

Vários trabalhos relatam variações na distribui ção, acumulação e suprimento de nutrientes na camada arável dos solos, de acordo com os sistemas de manejo adotados.

\subsubsection{Matéria orgânica}

Variações no teor e distribuição da matéria orgânica, bem como disponibilidade de nutrientes liberados pela mesma para o solo têm sido objeto de estudos em diferentes sis temas de preparo do solo.

Com relação à distribuição da matéria orgânica na camada arável do solo, GUEDES et alii (1979) e MUZILLI (1983) verificaram efeitos similares nos sistemas convencional e plantio direto, contrariando os resultados obtidos por LAL (1975., 1976), na Nigéria e BLEVINS et alii (1977) nos Es tados Unidos.

$$
\text { MUZILLI (1983) ressalta ainda a maior demanda }
$$
de $\mathrm{N}$ para culturas como milho e trigo em plantio direto, sugerindo a rotação gramínea/leguminosa para reduzir esta demanda.

Para PHILLIPS (1970) O $\mathrm{N}$ pode ser aplicado em. plantio direto assim como no sistema convencional, 
mas acrescido em $10 \%$ para compensar a imobilização causada por microrganismos, devido à grande quantidade de palha a ser decomposta.

A maior demanda de $\mathrm{N}$ pelas culturas em plantio direto é explicada pelo fato de que, havendo mais umidade presente no solo, existe maior movimento descendente de água, o que provoca maior lixiviação de nitratos. Além disso, a velocidade e o grau de mineralização da matéria orgânica é menor em plantio direto (MCMAHON e THOMAs, 1976).

objetivando relacionar teor de matéria orgānica com o tempo de cultivo, MUZILLI (1983) trabalhou com as sucessões de culturas: soja/trigo/soja, milho/trigo/milho e soja/ /trigo/milho, durante 5 anos de cultivo em Latossolo Roxo e 4 anos em Latossolo Vermelho Escuro. Verificou que houve um considerável acréscimo de matéria orgânica em ambos os solos com o decorrer do tempo, na camada de 0 a $30 \mathrm{~cm}$, tanto para o sistema de plantio direto como para o convencional.

\subsubsection{Fósforo}

Diversos trabalhos relatam a maior concentração de nutrientes na camada mais superficial do solo (0 a $10 \mathrm{~cm})$, em sistema de preparo em que o solo é pouco removido (SHEAR e MOSCHLER, 1969 e FINK e WESLEY, 1974).

Um dos nutrientes que tem sua distribuição em 
profundidade mais afetada pelo sistema de preparo do solo é o fósforo. No Brasil vários trabalhos têm relatado sobre o maior acúmulo de fósforo solúvel na camada superficial do solo e em sistemas de plantio direto reduzido (BEZERRA, 1978; GUEDES et alii, 1979; CENTURION et alii, 1982 e MUZILLI, 1983). Tal fato pode provocar um aumento de produtividade, como sugerem RAMOS e DEDECEK (1975) para a cultura da soja. Entretanto,a deficiên cia de fósforo solúvel nas camadas sub-superficiais do solo pode limitar a produtividade das culturas, em anos com ocorrência de veranico, em solos de cerrado (EMBRAPA/CPAC, 1980).

o maior acúmulo do fósforo nas camadas s.perficiais do solo, sob plantio direto, se explica pela imobilidade e baixa solubilidade de seus compostos, principalmente em solos ácidos e contendo altos teores de argila e metais pesados como $\circ \mathrm{Fe}$ e O Al (RAIJ, 1981).

2.1.3. Acidez, cálđio e magnésio

PHILLIPS (1970) propõe que para o caso de solos ácidos, antes do início do sistema sem preparo, o calcário seja incorporado ao solo como no sistema convencional.

Para SHEAR e MOSCHLER (1969), o fato do ânion nitrato remover consigo o cálcio no processo de lixiviação, su gere que a acidificação do solo seja mais intensa em plantio 
direto quando comparada com o convencional.

GUEDES et alii (1979), trabalhando com Latossolo Roxo e MUZILLI (1983) com Latossolo Roxo e Latossolo Vermelho Escuro, observaram que os valores de $\mathrm{pH}$ constatados em plantio direto mostraram-se superiores aos verificados em plantio convencional nos primeiros 5 ou $10 \mathrm{~cm}$ da camada arável. Esses resultados discordam daqueles obtidos por SHEAR e MOSCHLER (1969) e BLEVINS et alii (1978) que atribuiram a acidificação da cama da arável ao emprego de aitas doses de fertilizantes nitrogena dos no sistema de plantio direto.

Com relação a oxissolos de ceıłrado, RITCHEY et alii (1981) comentam que o crescimento das raizes no subsolo é frequentemente restringiäo pelo fato das raízes de várias plantas serem sensiveis à acidez.

Recentemente, MUZILLI (1983) constatou em Latos solo Roxo, maior concentração de $\mathrm{Ca}$ e $\mathrm{Mg}$ em plantio direto em relação ao sistema convencional nos primeiros 5 ou $10 \mathrm{~cm}$ da ca mada arável. Salienta o autor que isto ocorreu devido ao fato de, no início do ensaio, ter-se procedido à calagem sem incorporação de corretivo. Efeitos similares foram verificados por BLEVINS et alii (1978).

Entretanto em Latossolo Vermelho Escuro, onde não houve necessidade de correção de acidez, MUZILLI (1983) re lata que a distribuição de nutrientes, após vários anos, mostrou-se similar em ambos os sistemas de cultivo; houve inclusive aumento significativo de Ca nos primeiros $5 \mathrm{~cm}$ da camada ará- 
vel, para a cultura da soja.

\author{
2.1.4. Potássio, aluminio e capacidade de troca cátiô- \\ nica (CTC)
}

Pesquisando em Alfissol da Nigéria, LAL (1976) de

terminou teores maiores de $\mathrm{K}$ em sistema sem preparo do solo comparado aos tratamentos com preparo, isto na camada de 0 a $20 \mathrm{~cm}$ de profundidade. Porém, MUZILLI (1983) constatou em Latossolo 'rermelho Escuro que não houve variação significativa na camada arável entre os sistemas de plantio direto e convencional, sugerindo para este nutriente critérios de adubação se melhantes aos preconizados para o plantio convencional. Qs re sultados obtidos por MUZILLI (1983) confinmam os encontrados por SHEAR.e MOSCHLER (1969) após 6 anos de cultivo e por GUEDES et alii (1979) em Latossolo Roxo.

Com relação à distribuição do Al, BLEVINS et alii (1978) cita que o conteúdo de Al trocável aumenta com a profundidade em plantio direto, exceto na camada superficial de 0 a $5 \mathrm{~cm}$. Segundo este autor, o alto teor de matéria orgānica na superfície do solo influencia a relação entre o pH e o Al trocável.

GUEDES et alii (1978) concluíram após 5 anosicon secutivos de cultivos sucessivos de trigo e soja em plantio di reto, convencional reduzido, que os valores de Al tiveram dis- 
tribuição semelhante na profundidade de 0 a $20 \mathrm{~cm}$.

O alto teor de Al trocável em solos originalmen te sob vegetação de cerrado, tem sido considerado como um dos fa tores que afetam o desenvolvimento das raízes (KAWASAKI et alii, 1980)

LAL (1976), estudando a sucessão de cultura soja/soja, em sistemas sem preparo e com preparo do solo, encontrou maiores valores de CTC no sistema sem preparo na camada de 0 a $10 \mathrm{~cm}$ de profundidade. Entretanto, na camada de 10 a 20 cm, os maiores valores de СTC foram determinados em tratamen tos com preparo de solo.

\subsection{Teores de nutrientes do tecido vegetal em relação ao preparo do solo}

Considerando que o teor de nutrientes no solo é afetado pelos métodos de preparo do solo, é provável que também os teores de nutrientes do tecido foliar sejam influenciados pelos diferentes sistemas de preparo.

SMALL e OHLROGGE (1973) citam que, para o estágio de pleno florescimento, o teor de fósforo do tecido foliar da soja, é considerado suficiente se oscila entre $0,26 \%$ a $0,50 \%$. WIETHOLTER (1975), comparando sistemas de preparo do solo convencional, gradagem, subsolagem e sem preparo, ve rificou que o teor de fósforo na folha da soja é afetado pelo 
mesmo. O tratamento com subsolagem apresentou os menores valo res. Por outro lado, o teor de potássio nas folhas não foi afe tado pelos sistemas de preparo do solo. Contudo, Randall et alii (1973) citados por WIETHOLTER (1975), comparando os siste mas sem preparo e preparo com duas gradagens, não encontraram diferenças significativas nos teores de P, K, Ca e Mg das folhas da parte superior das plantas de soja.

PHILLIPS et alii (1980) atribuem a maior eficiência de aproveitamento de fósforo em plantio direto pelo fa to deste sistema apresentar maior teor de umidade na camada su perficial fivorecendo a taxa de difusão do fósforo até às raízes.

\subsection{Características físicas do solo em relação ao sistema de preparo}

A finalidade do preparo do solo é deixá-lo em condições de receber as sementes, além de controlar as ervas daninhas, pragas e doenças, e criar no solo condições físicas adequadas. No entanto, este objetivo nem sempre é :ałcançado, principalmente quando o cultivo é inadequado e intenso, o que tende a degradar as condições físicas do solo 


\subsubsection{Densidade do solo}

A densidade do solo a porosidade total têm sido usadas para avaliar indiretamente o estado de estrutura do solo, porque podem ser relacionados com a compactação do solo (REEVE et alii, 1973).

Entretanto, trabalhando com Latossolos, CORSINI

(1974) constatou que, embora os aumentos de densidade do solo estejam relacionados com o adensamento, esses aumentos não foram significativos a ponto de caracterizar possiveis mudanças na estrutura ocasionadas prlo cultivo intenso.

Como os sistemas de manejo do solo influenciam

os valores da densidade do solo, e, consequentemente, outras característi cas físicas, ela é de grande importāncia na avaliação de diferentes sistemas de preparo do solo (LARSON, 1964).

Assim, MACHADO e BRUM (1978) constataram aumentos significativos nos valores de densidade do solo nas pro fundidades de 0 a 15 e 15 a $30 \mathrm{~cm}$ para o preparo com arado de discos, quando comparado com o plantio direto.

MOURA (1981), estudando o efeito dos sistemas de manejo com arado de aiveca, arado de disco, grade pesada e plantio direto, verificou que o sistema grade pesada tendeu a apresentar valores médios elevados de densidade do solo até $45 \mathrm{~cm}$ de profundidade. 
2.3.2. Poøosidade total, macro e microporosidade

A porosidade total do solo engloba tanto o espa ço ocupado pela água como pelo ar.

A aeração, o movimento e o armazenamento de ãgua são frequentemente determinados pela natureza da estrutura do solo.

A aração visa aumentar a porosidade (GRIFFITH et alii, 1977), principalmente através dos macroporos (HEWITT e DEXTER, 1980).

Alguns autores constataram um decréscimo na porosidade total, quando se utiliza a grade após a operação de preparo do solo com arado (ALLMARAS et alii, 1970 e SALGADO, $1979)$.

Trabalhando com a cultura do mïlho, CHAVES (1977) verificou maiores valores na camada arável, para a porosidade total no tratamento arado de disco, quando comparado com arado de aiveca, grade pesada e plantio direto.

Através de análises de um Latossolo Roxo, MACHA DO e BRUM (1978) concluiram haver efeitos do sistema convencio nal de cultivo, em relação ao plantio direto, com diminuição da porosidade total, macroporosidade e aumento da microporosidade do solo, nas profunäidades de 0-15 e 15-30 cm. 


\subsubsection{Resistência do solo à penetração}

A resistência do solo à penetração é o fator fí sico de crescimento que representa a resistēncia que a raiz en frenta ao crescer (FORSYTHE, 1967).

Também TAYLOR e BURNETT (1964) comprovaram que a resistēncia do solo à penetrạção, medida com um penetrōmetro, é o principal fator físico que controla o desenvolvimento das raỉzes. Uma resistēncia de $26 \mathrm{~kg} / \mathrm{cm}^{2}$ a $34 \mathrm{~kg} / \mathrm{cm}^{2}$ em um solo franco-arenoso fíno na capacidade de campo impediu a penetração de raīzes de uma série de plantas, mas com uma resistência de $20 \mathrm{~kg} / \mathrm{cm}^{2}$, as raízes crescem. Consideraram $26 \mathrm{~kg} / \mathrm{cm}^{2}$ o limite crîtico de resistência para este solo.

Os dados de resistēncia à penetração variam com a textura e com a umidade do solo. Segundo BAVER et alii (1973), solos arenosos apresentam menor resistência à penetração do que solos argilosos, o que é explicado pela força de coesão menos intensa que os grãos de areia apresentam. Quanto ao efeito da : umidade, TAYLOR e RATLIFF (1969) citam a diminuição da resistência à penetração a aumentos na umidade do solo.

PHILLIPS e KIRKHAM (1962), em experimento de campo na cultura do milho, utilizaram compactação normal, mode rada e severa, verificando que a compactação reduziu o rendi. mento que os fatores de impedimento mecânico, medidos pela densidade do solo e pela resistēncia do solo à penetração, foram as propriedädes físicas mais altamente correlacionadas ao 
crescimento e ao rendimento do milho.

Analisando os sistemas de preparo do solo; convencional, gradagem, subsolagem e sem preparo, WIETHOLTER (1975) determinou que os sistemas convencional e subsolagem ofereceram menores valores de resistēncia do solo à penetração, nas profundidades de 10 e $25 \mathrm{~cm}$, respectivamente. Argumenta o autor que isto ocorreu porque a lavra no preparo convencional foi feita à $20 \mathrm{~cm}$ e a subsolagem à $30 \mathrm{~cm}$ de profundidade.

SILVA (1980) encontrou valores elevados de resistência à penetração em Jatossolo Roxo com cultivo convencio nal, plantio direto e área desmatada com trator de esteira, in dicando a formação de uma camada compactada que provoca desvio nas raizes de soja.

As causas e fatores que influem no desenvolvi mento do sistema radicular da soja cultivada no cerrado, foram estudadas por KAWASAKI et alii (1980). Os autores verificaram que o manejo dado aos solos pode aumentar ou diminuir o grau de compactação dos mesmos. Encontraram grau de compactação variando de 2,5 a $15 \mathrm{~kg} / \mathrm{cm}^{2}$, alcançando valores máximos ao redor dos $25 \mathrm{~cm}$ de profundidade.

2.3.4. Infiltração e retenção de água

Vários resultados experimentais têm demonstrado que cultivos inadequados e intensivos contribuem para a de- 
gradação das propried

bre a infiltração e

dä ao surgimento de

BAUMER e BAKERMANi

filtração d'água

gua a maiores suc s físicas do solo. Essa degradáção soação d'água no solo, é justamente devi las compactadas. Conforme sievidenciam - estas camadas além de diminuir a in são responsáveis pela retenção d'áque dificulta a sua absorção pelas plantas.

A textura do solo e o teor de matéria orgānica exercem efeitos na retenção d'água. Assim, geralmente, quanto maior o teor de argila, maior será ò conteúdo de água sob dada sucção (HILLEL, 1970). Já a matéria orgānica, segundo REEVE et alii (1973), retém água no solo a baixas tensões.

LAL (1976) verificou que o teor de umidade do solo, principalmente na profundidade de 0 a $10 \mathrm{~cm}$, e a taxa de infiltração d'água foram mais elevadas no sistema sem prepa ro do solo do que nas parcelas preparadas. Atribui a diferença ña capacidade de retenção de umidade ao conteúdo de matéria or gânica e à diferença na textura da superfície do horizonte das parcelas preparadas.

Avaliando os efeitos de sistemas de manejoe tem po de cultivo sobre as propriedades físicas de um Latossolo Roxo (Haplorthox), SILVA (1980) constatou uma sensível redução na velocidade de infiltração de água nas áreas sob plantio direto, cultivada com implemento tracionado por boi, desmatada com trator de esteira e cultivada convencionalmente, em relação à área sob mata. redução é atribuída à forte camada de compactação,a qual é res- 
ponsável ainda pela maior retenção de água, resultante da maior microporosidade apresentada por essa camada.

Trabalhando com Latossolo Roxo Distrófico, SIDI RAS et alii (1983) constataram maior teor de água nas parcelas de plantio direto em relação às de plantio convencional, para a camada de 0-20 cm. Isto resultou em maior rendimento médio de soja no sistema de plantio direto.

2.4. Características aqronômicas em relação ao preparo do solo

No preparo do solo deve ser levado em conta um conjunto de objetivos a que o mesmo se destina, dentre eles a germinação de sementes, àltura de inserção das vagens e distribuição do sistema radicular, que irão influir na produtividade da cultura.

$$
\text { 2.4.1. "stand" }
$$

Para QUEIROZ et alii (1979) e BARNI e BERGAMASCHI (1981) a população de $400 \mathrm{mil}$ plantas por hectare tem proporcionado as melhores respostas para as diversas caracteristi cas agronômicas da planta àe soja. Com densidades elevadas a produção por planta diminui, devidoà competição intra-específica. 
KINCADE (1972) e WIETHOLTER (1975) não encontra ram diferenças na densidade de plantas de soja entre os métodos de preparo convencional e sem preparo. O primeiro autor observou também que no método sem preparo as plantas germinaram mais rapidamente.

Por outro lado, RAMOS (1981) observou em .trabalhos experimentais e mesmo em lavouras comerciais no Paraná, me lhor germinação e maior número de plantas de soja emergidas no plantio direto, em relação ao sistema convencional.

A formação de crosta, em solos reviolvidos, pode acarretar sérios problemas, principalmente para a germinação da soja (RAMOS, 1981). A cobertura de residuos do plantio direto virtualmente elimina o problema. Também OHMURA e HOWELL (1960) relatam que chuvas pesadas imediatamente após o plantio causam a compactação superficial e formação de crosta em alguns tipos de solos.

\author{
2.4.2. Alturas da planta e da inserção da primeira \\ vagem
}

A altura de plantas está relacionada com a altụ ra de inserção das primeiras vagens e aumenta com a população (QUEIROZ et alii, 1979). Es.ta relação deve ser aproveitada para estabelecer uma cultura com o máximo de rendimento e adapta ção estrutural à colheita mecānica. 
Trabalhando nos Estados Unidos, KINCADE

verificou que 90 dias após a semeadura, alaltura de plantas foi uniforme nos métodos de preparo convencional e sem preparo na cultura da soja.

Já WIETHOLTER (1975), em pesquisas no Rio Gran de do Sul, observou que o método de preparo convencional proporcionou plantas maiores aos 58 dias após a semeadura da soja, em relação ao método sem preparo.

\subsubsection{Sistema radicular}

A intensidade do cultivo afeta as propriedades biológicas, físicas e quimicas do solo, e o efeito destas no crescimento das raízes varia de acordo com as condições iniciais do solo (CANNELL, 1981).

Para VIEIRA (1981), um dos parâmetros envolvidos com o crescimento do sistema radicular é a resistência mecânica do solo, sendo esta, variável com o conteúdo de água no perfil. O autor constatou que o maior adensamento verificado na camada superficial do solo em plantio direto, não foi suficiente pa ra afetar o crescimento radicular das plantas de soja, sugerin do que o conteúdo de água mais elevado e mais estável, tenha contribuído para a diminuição da resistência mecânica à pene tração das raỉzes.

Procurando determinar os efeitos dos sistemas 
de preparo do solo e dos métodos de aplicação de fertilizantes na produção da cultura da soja, RAMOS e DEDECEK (1975) encon traram que os métodos de cultivo reduzido proporcionaram altas concentrações de raízes na camada mais superficial do solo, que, sendo mais fértil, teria acarretado as produções mais altas, neste tipo de preparo do solo.

\subsubsection{Rendimento}

Resultados de sistemas de preparo reduzido do solo na cultura da soja, nos Estados Unidos, têm indicado que os rendimentos obtidos com os sistemas de preparo reduzido foram se melhantes ou mesmo superiores àqueles obtidos com $\circ$ sistema convencional de preparo'do solo, como citam KINCADE (1972) e LEWIS (1972).

No Brasil, poucos trabalhos com esse objetivo têm sido conduzidos. De modo geral, os resultados das pesquisas têm indicado que os rendimentos de soja, ao se considerar os efeitos médios de várias safras, equivalem-se em diferentes sistemas de cultivo.

GUEDES et alii (1979) relatam estudo comparativo entre três sistemas de cultivo na região norte do Paraná; após 5 anos de cultivo sucessivo com trigo, a soja não apresen tou diferenças significativas, ao se comparar as médias de ren dimento em plantio direto, preparo reduzido e plantio convencional. 
Estudando a influência na produção de soja dos preparo de solo: uma aração e duas gradagens, duas gradagens, en xada rotativa e semeadura direta, na Terra Roxa Estruturada e Latossol Vermelho Escuro, GAMERO et ai $i i$ (1979) observaram que não há influência significativa de sistemas de preparo do solo nas produções, nos dois tipos de solo.

Em pesquisa recente, SIDIRAS et alii (1983) encontraram rendimentos médios de soja superiores em plantio direto, em relação a escarificação e preparo convencional, isto pą ra um período de três anos de cultivo.

\subsection{Viabilididade econômica}

Estudando os aspectos econômicos das técnicas de preparo do solo e implantação da cultura da soja, TOMASINI e PERETTI (1977), no Rio Grande do Sul, concluíram que o siste ma de semeadura direta é mais oneroso que o sistema convencio nal, necessitando produzir no minimo $70 \mathrm{~kg}$ de soja a mais por hectare, para ser mais econōmico. Consideram, no entanto, que outros fatores de diversas ordens, como o melhor rendimento por antecipação da época de plantio, melhor germinação decorrente da melhor conservação de água no solo, redução de investimento de máquinas por hectare, redução do consumo de combustíveis., lubrificantes e mão-de-obra, possibilidade de novas combina ções de culturas, devido à economia de tempo no plantio, permi 
tem concluir pela maior economicidade da semeadura direta. LAURENTI e FUENTES (1981) evidenciam que a simi laridade de custos entre o plantio convencional e o plantio di reto se deve ao fato de que a diminuição de gastos com preparo de solo no plantio direto foi neutralizada pelos gastos referentes ao controle de ervas daninhas.

Considerações semelhantes são feitas por RAMOS (1981), sendo que o autor ainda ressalta que, utilizando o preparo reduzido com grade: niveladora, pode-se estimar menor custo total, uma vez que a técnica de controle de invasoras será a mesma do sistema convencional. 


\section{MATERIAL E METODOS}

\subsection{L̇oolização e descrição da área experimental}

O presente trabalho foi conduzido na área expe-rimental da Universidade Estadual Paulista - "Campus" de Ilha Solteira, situada no município de Selvíria, Estado de Mato Gros so do sul.

O solo local foi classificado como Làtossól Ver melho Escumo Álico (Acrustox), de textura argilosa por:DEMATTE (1980). A declividade média é de cerca de $3 \%$.

Selviria está localizada na bacia hidrográfica do Paraná apresentando altitude de $335 \mathrm{~m}$, temperatura média anual de $24,6^{\circ} \mathrm{C}$. A latitude é de $20^{\circ} 22^{\prime}$ 's e a longitude, de $51^{\circ} 22^{\prime}$ 'W.Gr. A precipitação média anual é de $1330 \mathrm{~mm}$, a evapotranspiração po tencial média é de $1226 \mathrm{~mm}$ e o tipo climático segundo o sistema de Köppen é Aw. 
A vegetação original desta área era de cerrado, a qual foi desmatada em maio de 1978, com auxílio de correntão (derrubada) e lâmina (enleiramento). A Tabela 1 apresenta características químicas e granulométricas do solo estudado, por ocasião do desmatamento. Após esta operação preparou-se conven cionalmente o solo para a cultura da soja (semeada em 11/1978). Assim que esta foi colhida, aplicaram-se na área os sistemas de preparo do solo: convencional, reduzido e semeadura direta e implantaram-se as culturas de sorgo e trigo.

Deste modo, utilizaram-se as sucessōes soja/trigo e soja!'sorgo, em todos os sistemas de preparo de solo, durante três anos agrícolas $(1978 / 79,1979 / 80$ e 1980/81).

3.2. Adequação da área e tratamentos

Utilizando-se da área descrita anteriormentefoi feita a distribuição dos tratamentos, sendo que parte da área destinada ao preparo convencional foi utilizada para o trata mento denominado de superpreparo. A metade de todas as parcelas receberam adubação de correção total (ACT) e toda a área das parselas tiveram adubação parcelada (AP) .

Convém ressaltar que toda a área experimental recebeu em 10/1981, 4 t/ha de calcário dolomítico, para uma meIhor adequação. 


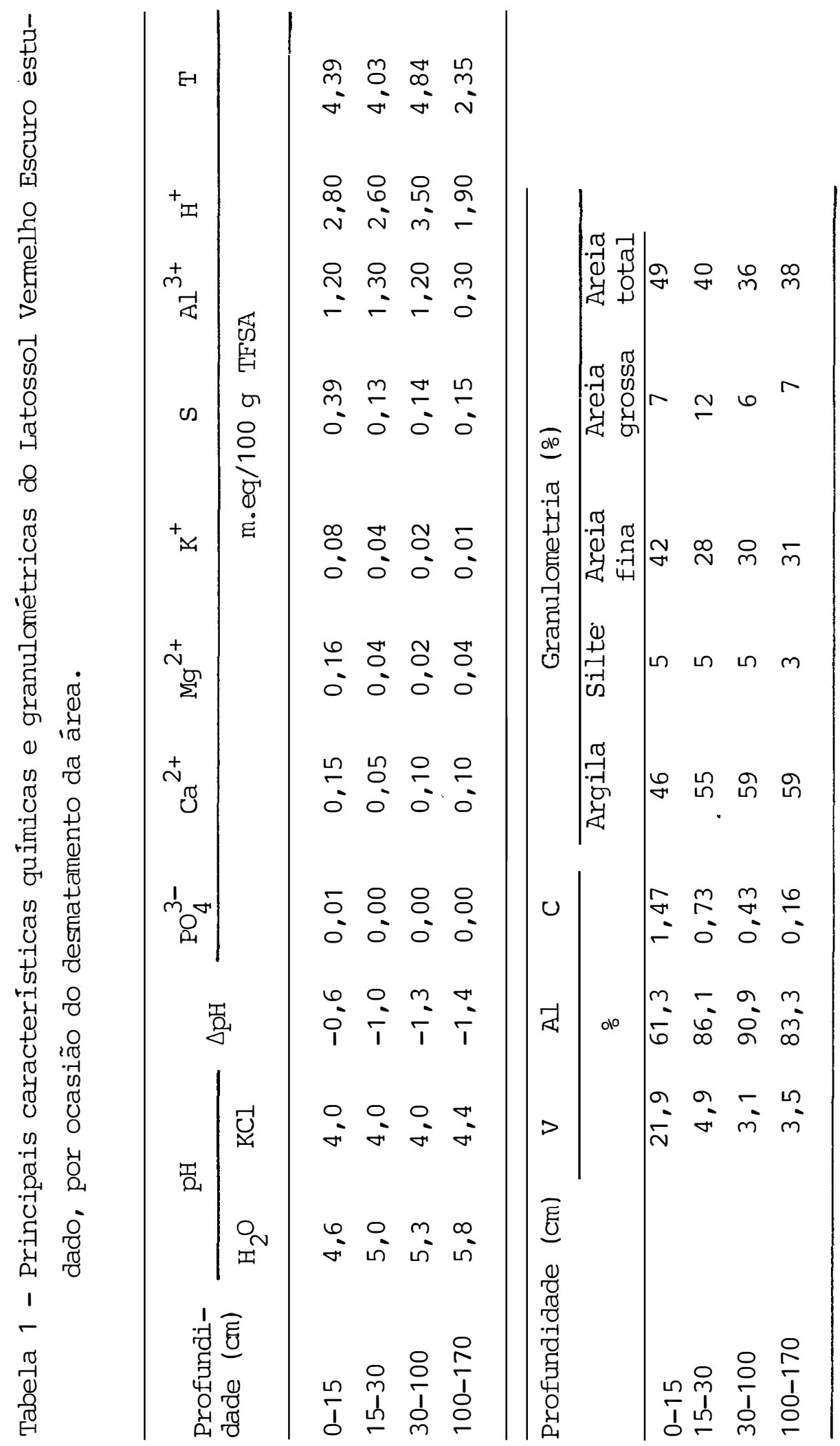


Desta maneira, os tratamentos ficaram assim distribuídos:

1. Sistema Convencional + Adubação de Correção Total (SC + ACT)

2. Sistema Convencional + Adubação Parcelada (SC + AP)

3. Sistema Reduzido + Adubação de Correção Total (SR + ACT)

4. Sistema Reduzido + Adubação Parcelada (SR + AP)

5. Super Preparo + Adubação de Correção Total (SP + ACT)

6. Super Preparo + Adubação Parcelada (SP + AP)

7. Semeadura Direta + Adubação de Correção Total (SD + ACT)

8. Semeadura Direta + Adubação Parcelada (SD + AP)

A Tabela 2 apresenta a descritição de todas as operações realizadas para a instalação do experimento.

- O delineamento experimental utilizado foi en blo cos ao acaso segundo PIMENTEL GOMES (1977), com os tratamentos distribuidos em faixas, tendo como tratamento principal o preparo do solo e os modos de adubação como tratamento secundá rio. Cada parcela 'constou de $50 \mathrm{~m}$ x $15 \mathrm{~m}\left(750 \mathrm{~m}^{2}\right)$ de área total, tendo $20 \mathrm{~m}$ x $6 \mathrm{~m}\left(120 \mathrm{~m}^{2}\right)$ de área útil e 5 repetições. 
Tabela 2 - Discriminação das operações para cada tratamento nos ános agrícolas 1981/82 e 1982/83.

\begin{tabular}{|c|c|c|}
\hline & \multicolumn{2}{|c|}{ Ano agrícola } \\
\hline & $1981 / 82$ & $1982 / 83$ \\
\hline 1. $\mathrm{SC}+\mathrm{ACT}$ & $\begin{array}{l}\text { calagem } \\
\text { aração } \\
\text { adubação corretiva total } \\
\text { gradagem pesada } \\
\text { gradagem niveladora } \\
\text { plantio e adubação }\end{array}$ & $\begin{array}{l}\text { aração } \\
\text { gradagem pesada } \\
\text { gradagem niveladora } \\
\text { plantio e adubação }\end{array}$ \\
\hline 2. $S C+A P$ & $\begin{array}{l}\text { calagem } \\
\text { aração } \\
\text { gradagem pesada } \\
\text { gradagem niveladora } \\
\text { plantio e adubação }\end{array}$ & $\begin{array}{l}\text { aração } \\
\text { gradagem pesada } \\
\text { gradagem niveladora } \\
\text { plantio e adubação }\end{array}$ \\
\hline 3. $\mathrm{SR}+\mathrm{ACT}$ & $\begin{array}{l}\text { calagem } \\
\text { gradagem pesada } \\
\text { adubação corretiva total } \\
\text { gradagem pesada } \\
\text { gradagem niveladora } \\
\text { plantio e adubação }\end{array}$ & $\begin{array}{l}\text { gradagem pesada } \\
\text { gradagem niveladora } \\
\text { plantio e adubação }\end{array}$ \\
\hline 4. $S R+A P$ & $\begin{array}{l}\text { calagem } \\
\text { gradagem pesada } \\
\text { gradagem pesada } \\
\text { gradagem niveladora } \\
\text { plantio e adubação }\end{array}$ & $\begin{array}{l}\text { gradagem pesada } \\
\text { gradagem niveladora } \\
\text { plantio e adubação }\end{array}$ \\
\hline 5. $\mathrm{SP}+\mathrm{ACT}$ & $\begin{array}{l}\text { calagẹn } \\
\text { aração } \\
\text { adubação corretiva total } \\
\text { aração } \\
\text { gradagem pésada } \\
\text { gradagem niveladora } \\
\text { plantio e adubação }\end{array}$ & $\begin{array}{l}\text { aração } \\
\text { aração } \\
\text { gradagem pesada } \\
\text { gradagem niveladora } \\
\text { plantio e adubação }\end{array}$ \\
\hline 6. $\mathrm{SP}+\mathrm{AP}$ & $\begin{array}{l}\text { calagem } \\
\text { aração } \\
\text { aração } \\
\text { gradagem pesada } \\
\text { gradagem niveladora } \\
\text { plantio e adubação }\end{array}$ & $\begin{array}{l}\text { aração } \\
\text { aração } \\
\text { gradagem pesada } \\
\text { gradagem niveladora } \\
\text { plantio e adubação }\end{array}$ \\
\hline 7. $S D+A C T$ & $\begin{array}{l}\text { calagem } \\
\text { adubação corretiva total } \\
\text { roçada } \\
\text { aplicação de herbicida } \\
\text { plantio e adubação }\end{array}$ & $\begin{array}{l}\text { roçada } \\
\text { aplicação herbicida } \\
\text { plantio e adubação }\end{array}$ \\
\hline 8. $S D+A P$ & $\begin{array}{l}\text { calagem } \\
\text { roçada } \\
\text { aplicação herbicida } \\
\text { plantio e adubação }\end{array}$ & $\begin{array}{l}\text { roçada } \\
\text { aplicação herbicida } \\
\text { plantio e adubação }\end{array}$ \\
\hline
\end{tabular}

Obs.: Aração realizada com arado de discos a uma profundidade aproximada de 20 a $25 \mathrm{~cm}$; gradagem pesada realizada com grade tipo ROME a uma pro fundidade aproximada de 10 a $15 \mathrm{~cm}$. 


\title{
3.3. Práticas culturais
}

\author{
3.3.1. Semeadura
}

A soja [Glycine max (L.) Merril], cv. Paraná, foi semeada no espaçamento de $50 \mathrm{~cm}$ entre linhas e com 30 a 35 sementes/m, com uma densidade de semeadura de 70 a $90 \mathrm{~kg} / \mathrm{ha}$.

Para o ano agrícola 1981/82 esta operação ocorreu em 14/11/81 e no ano agrícola 1982/83 a mesma foi feita em 30/10/1982. Nos sistemas convencional, reduzido e de superpreparo utilizou-se a.semeadora Jumil, enquainto para o sistema de semeadura direta empregou-se a semeadora-adubadora do tipo Rotacaster.

\subsubsection{Controle de ervas daninhas}

No ano agrícola 1981/82 utilizou-se da mistura dos herbicidas alachlor $(5,0$ litros/ha) e metribuzin 10,7 litro/ha) aplicados em pré-plantio, para os sistemas convencional, reduzido e de superpreparo. Decorridos 30 dias após a germinação da soja houve ainda a necessidade de uma capina mecânica nestes sistemas. Na semeadura direta aplicou-se uma mistura de pa raquat $(3,0$ litros/ha) e metribuzin $(0,7$ litro/ha) em pré-plan tio. Neste sistema foi necessária a realização de uma capina manual com enxada aos 30 dias após a germinação da soja. 
Para o ano agrícola seguinte aplicou-se o herbi cida paracol (2 litros/ha) em pré-plantio nas parcelas de semeadura direta. Empregou-se também,para todos os tratamentos,a mistura dos herbicidas poast $(2,0$ litros/ha) e basagram $(1,5$ litros/ha) juntamente com o adjuvante oleoso assist (3,0 litros) ha) aplicados em pós-emergência, 35 dias após a germinação da soja.

\subsubsection{Adubação}

(i)

- A adubação de correção total (ACT) consistiu de $400 \mathrm{~kg} / \mathrm{ha}$ de $\mathrm{P}_{2} \mathrm{O}_{5} 100 \mathrm{~kg} / \mathrm{ha}$ de $\mathrm{K}_{2} \mathrm{O}$, aplicados a lanço em 06/11/81, nas parcelas correspondentes a este tratamento. Todas-as parcelas receberam por ocasião da semeadura 200 kg/ha da fórmula 4-20-20 e $50 \mathrm{~kg} / \mathrm{ha}$ de FTE-BR 9, aplicados no sulco de plantio, sendo esta adubação denominada no presente trabalho como adubação parcelada (AP) .

No ano agrícola $1982 / 83$ a adubação parcelada (AP) foi realizada através da aplicação de $300 \mathrm{~kg} / \mathrm{ha}$ da fórmula 5-30-15 por ocasião da semeadura, em todas as parcelas experimentais. Portanto, as parcelas denominadas ACT, neste ano agrí cola, receberam apenas adubação parcelada. 


\subsection{Avaliação}

\subsubsection{Análises químicas do solo e do tecido foliar}

Foram retiradas amostras do solo, nas profundidades de: 0-5, 5-10, 10-15, 15-20, 20-25, 25-30, 60 e 90 cm, pa ra análises químicas, em três épocas (anterior ao plantio, no meio e no final do ciclo da cultura). As amostras foram retira das com duas repetições, na linha e na entrelinha da cultura. Coletaram-se com auxílio de trado em 5 pontos de cada parcela amos tras simples de solo para formação de amostra composta.

Efetuaram-se as seguintes análises quimicas do so 10: $\mathrm{C}, \mathrm{pH}, \mathrm{P}, \mathrm{K}^{+}, \mathrm{Al}^{+++}, \mathrm{Ca}^{++}+\mathrm{Mg}^{++}$e $\mathrm{CTC}$ ao $\mathrm{pH} 7,0$. As marchas analiticas para a caracterização química seguiram :a seguinte orientação: pH em água na relação 1:2,5; K trocável: ex tração $\mathrm{com}_{2} \mathrm{SO}_{4}, 0,05 \mathrm{~N}$ e determinação pelo fotômetro de chama; P solúvel: extração $\mathrm{com}_{2} \mathrm{SO}_{4} 0,05 \mathrm{~N}$, relação solo: solução $1: 10$ e agitação durante 5 minutos; $\mathrm{Al}^{+3}$ trocável: extração com $\mathrm{KCl}$ N e titulação com $\mathrm{NaOH} 0,025 \mathrm{~N} ; \mathrm{Ca}^{2+}+\mathrm{Mg}^{2+}$ trocáveis: extração com KCl N e titulação com EDTA 0,025 N; conforme o descrito em RAIJ e ZULLO (1977). Enquanto que o carbono orgânico (\%) foi determinado com bicromato de potássio $0,4 \mathrm{~N}$ e titulação com sulfato ferroso amoniacal 0,1N, conforme descrito em VETTORI (1969). A CTC foi determinada segundo GLORIA et a lii (1965).

Para a realização das análises de micronutrien tes (cobre, ferro, manganês e $\mathrm{z}$ inco) coletaram-se amostras nas 
profundidades de $0-5,5-10,10-15,15-20$ e $60 \mathrm{~cm}$. Procedeu - se à coleta antes do 29 ano de cultivo da soja. Utilizou-se como solução extratora ácido sulfúrico $1 \mathrm{~N}$ e ácido clorídrico $1 \mathrm{~N}$, sen do que as leituras foram feitas em espectrofotômetro de absorção atômica Perkin Elmer mod. 303.

Executaram-se também análises do tecido foliar, pa ra determinação dos teores de $\mathrm{N}, \mathrm{P}, \mathrm{K}^{+}, \mathrm{Ca}^{2+} \mathrm{e} \mathrm{Mg}^{2+}$. As amostras foram coletadas no estágio de plena floração. o nitrogênio foi determinado por digestão sulfúrica pelométodo Kjeldahl. Para os demais nutrientes houve digestão nîtrica-perclórica, sen do o potássio determinado pelo fotômetro de chama; para o cálcio e magnésio a leitura foi feita através de titulação com per manganato de potássio; o fósforo foi determinado pelo método do vanadato molibdato de amônio com leitura em colorímetro.

\subsubsection{Análises físicas do solo}

A composição granulométrica foi determinada por sedimentação e tamisação empregando-se $\mathrm{NaOH}$ como agente de dis persantee agitação horizontal. Utilizou-se do método da pipeta descrito por DAY (1965).

A caracterização dos efeitos dos diferentes sis temas de preparo do solo sobre as caracteristicas físicas deste foi feita através de determinações executadas logo após o plantio e no final do ciclo da cultura da soja, sendo que para 
cada ēpoca as análises foram realizadas com duas repetições nos dois anos agrícolas estudados.

A densidade do solo foi determinada segundo método descrito por BLAKE (1965), utilizando-se anéis de volume conhecido (h de $7,0 \mathrm{~cm}$ e $\phi$ de $6,2 \mathrm{~cm}$ ) para a coleta das amostras, sendo estas feita nas profundidades de $0-7 \mathrm{~cm}, 10-17 \mathrm{~cm}$, $20-27 \mathrm{~cm}$ e $60-67 \mathrm{~cm}$.

Nas mesmas profundidades, com 10 leituras por parcela, foram feitas as determinações de resistência do solo à penetração, avaliada com penetrômetro Solotest - ref. S 210 com um diâmetro da base do cone de $2,4 \mathrm{~cm}$ e uma profundidade de penetração de $5,5 \mathrm{~cm}$. A aplicação do penetrômetro foi reali żada perpendicularmente à superfỉcie do solo. Ao mesmo tempo, nes tas profundidades foram feitas amostragens do solo para deter minação da umidade gravimétrica, segundo método descrito por HILLEL (1970) •

Além das análises físicas, foram realizadas no ano agrícola 1982/83 algumas determinações físico-hídricas. Através de anéis com $\mathrm{h}$ de $3,0 \mathrm{~cm}$ e $\phi$ de 5,4 cm introduzidos por percussão e perpendicularmente ao solo, coletaram-se amostras para a determinação da umidade a diferentes tensões. As amostras foram coletadas nas profundidades: 0-3 cm, 10-13 cm, 20$-23 \mathrm{~cm}, 40-43 \mathrm{~cm}$ e 60-63 cm. Após saturadas foram colocadas em funis de placa porosa (funil de Buchner) e submetidas às tensões de 0,01 e 0,06 atmosfera. Para determinação dos valores das massas de solo úmido referentes às tensões de $0,1,0,33$, 
0,60 e 1,0 atmosfera foi empregada a placa porosa de RICHARDS (1947). Os valores das massas de solo seco foram obtidos mediante a secagem das amostras em estufa à 105-1100C até peso constante. Considerou-se a tensão de 0,001 atmosferas para os valores das massas de solo saturado.

Para a medida da umidade no campo foi instalada uma bateria de três tensiōmetros com manōmetro de mercūrio, em todos os tratamentos. Os tensiōmetros foram instalados nas profundidades de 20,40 e $60 \mathrm{~cm}$. A determinação do potencial ma tricial foi feita através da leitura da altura da coluna de mer cürio do tensiōmetro e aplicando-se a fórmula $\psi_{m}=-\left(12,6 h-h_{1}-h_{2}\right)$ citada por REICHARDT (1975).

A umidade do solo foi determinada pela interpolação dos valores do potencial da água do solo à curva de retenção de āgua.

A microporosidade foi obtida a partir dos dados da curva de retenção de água, considerando-se como microporosi dade o volume relativo de áqua retida no solo à tensão de 0,06. atmosfera. A macroporosidade foi determinada em função da dife rença da massa do solo saturado menos a massa do solo submetido à tensão de 0,06 atmosfera. A porosidade total avaliada é expressa pela soma da micro e macroporosidade.

Na determinação da taxa de infiltração de água no solo utilizou-se o método de inundação com infiltrômetro de duplos cilindros concêntricos, descrito por BERTRAND (1965) . A velocidade de infiltração de água no solo foi determinada nos 
seguintes intervalos a partir do tempo zero: 1, 3, 5, 10,15, 25, $35,50,65,95,125,185$ e 245 minutos.

\subsubsection{Caracteristicas agronômicas}

Aos 15 dias após a semeadura procedeu-se à avaliação da densidade de plantas ("stand"). Contaram-se as plantas nos 240 metros lineares da área útil da parcela.

A medição das alturas da planta e inserção da primeira vagem foram feitas, respectivamente, por ocasião do flo rescimento e maturação das plantas. Mediram-se 15 plantas ao aca so na parcela útil.

A avaliação do sistema radicular foi feita com duas repetições. Escolheram-se cinco piläntas consecutivas de uma mesma linha, ao redor das quais foram abertas trincheiras com um blo co monolítico em seu interior de $0,20 \mathrm{~m} \times 0,15 \mathrm{~m} \times 0,20 \mathrm{~m}$ de comprimento, largura e profundidade, respectivamente. Este blo co foi seccionado, juntamente com as raízes. O solo correspondente a cada seção foi lavado com água, para separar o: solo do sistema radicular das plantas. As raìzes limpas foram secas em estufa à $105^{\circ} \mathrm{C}$ durante 24 horas, pesadas a seguir em balan ça analítica de precisão, para determinação do peso seco.

Colheram-se os grãos mecanicamente em 17/02/82 e 24/02/83, respectivamente para os anos agricolas 1981/82 e 1982/83. A colheita foi feita na área correspondente à parcela 
útil, ou seja $120 \mathrm{~m}^{2}$. O peso de grãos foi ajustado para $14 \%$ de umidade.

Após a colheita determinou-se o peso de 100 grãos, coletados ao acaso, para todos os tratamentos, tomando-se como base o teor de $14 \%$ de umidade dos grãos.

3.4.4, Viabilidade econōmica

o custo de produção para os diversos tratamen tos estudados, foi calculado com base no custo operacional ado tado pelo Instituto de Economia Agrícola, segundo metodologia descrita por MATSUNAGA et alii (1976).

A receita foi obtida através da comercialização de sacas de soja, vendidas respectivamente a $\operatorname{Cr} \$ 2.000,00$ e Cr\$3.800,00 por saca de $60 \mathrm{~kg}$ nos anos agrícolas de 1981/82 e $1982 / 83$.

o resíduo foi obtido através da diferença entre receita e custo operacional total. A taxa residual é dada pela relação entre o valor do resíduo e o custo operacional total, representando a taxa de remuneração dos fatores fixos (terra, capital e empresáriol. 


\title{
4. RESULTADOS E DISCUSSÃO
}

\author{
4.1. Caracteristicas quimicas do solo.
}

Os valores médios de matéria orgânica, fósforo, potássio, cálcio + magnésio, saturação de aluminio, CTC e pH são apresentados nas Figuras 1 à 7 .

Para matéria orgânica, nos dois anos agrícolas estudados, esses valores (Figura 1) revelam um acúmulo na camą da mais superficial do solo, 0 a $5 \mathrm{~cm}$, 'nos sistemas reduzido e semeadura direta. Isto ocorre devido ao menor revolvimento do solo, principalmente quando se emprega a semeadura direta, como foi constatado por BLEVINS et ali $i$ (1977). O sistema reduzido, pelo fato de somente utilizar grade pesada para o preparo do solo, também propicia condições para uma melhor distribuição dos resíduos orgânicos nas camadas superficiais, como consta tou MOURA (1981). 

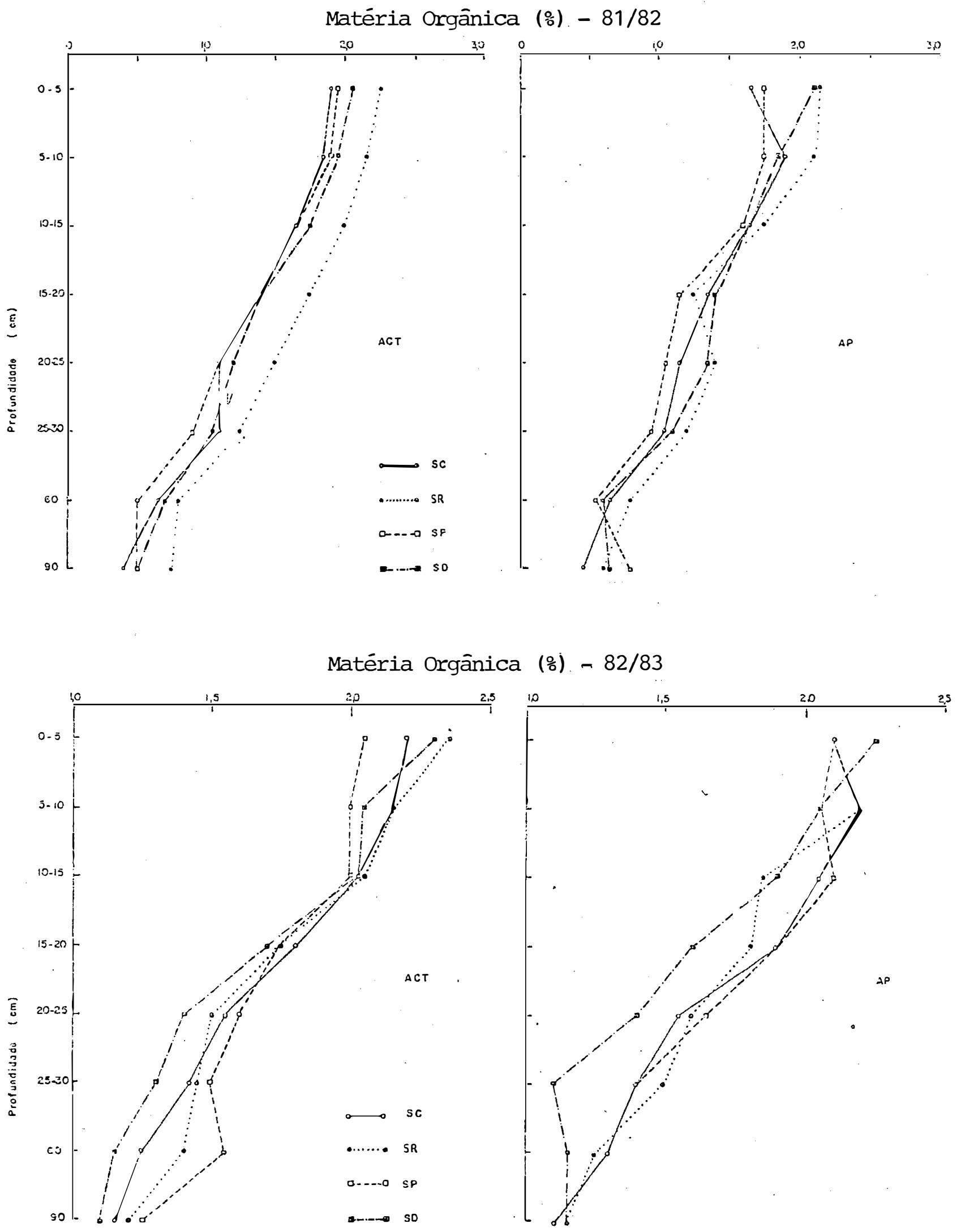

Figura 1 - Valores médios de matéria orgânica (\%), abtidos em diferentes profundidades do solo, referentes aos diversos tratamentos estudados nos anos agrícolas $1981 / 82$ e 1982/83. 

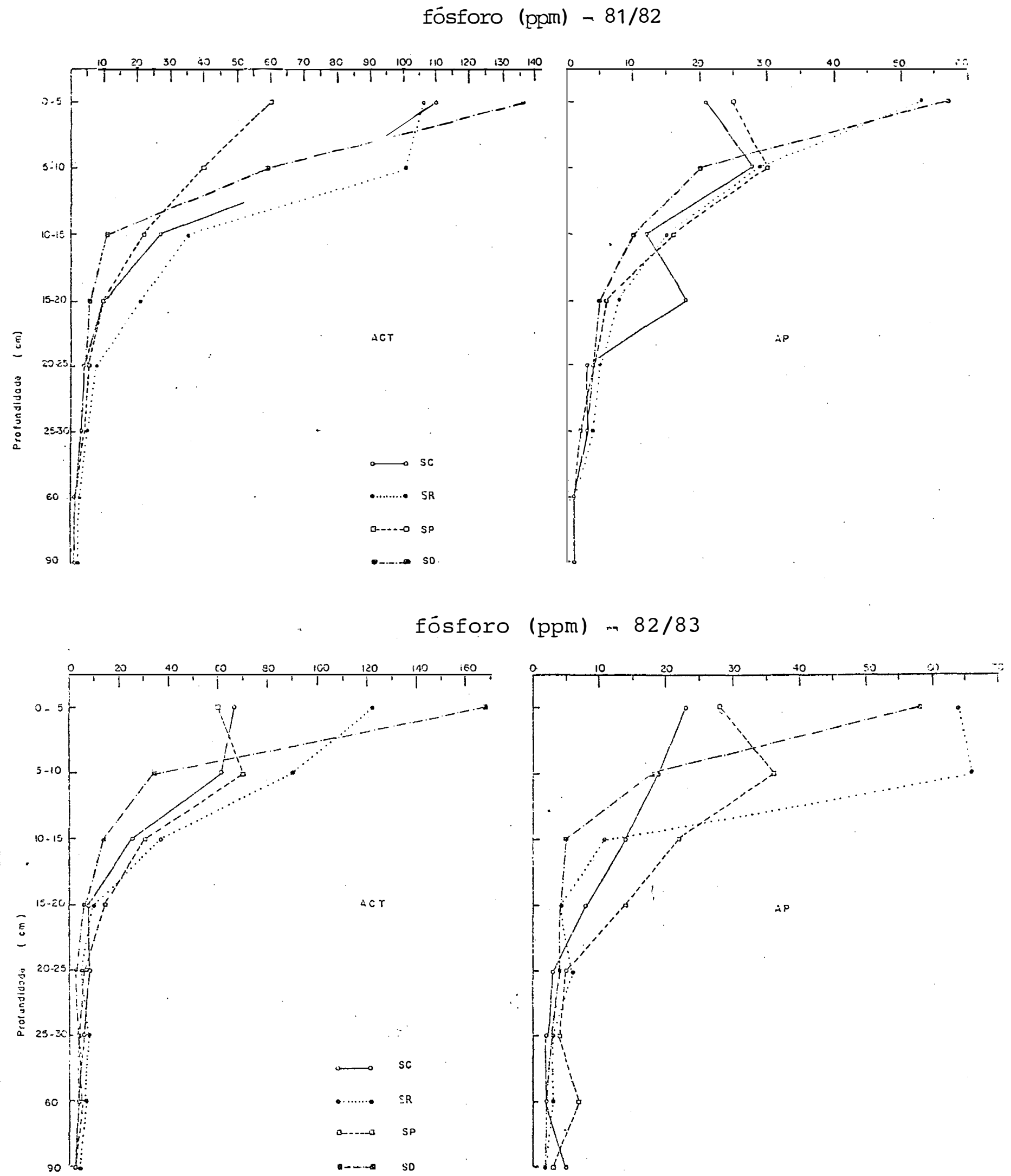

Figura 2 - Valores médios de fósforo solúvel (ppm), obtidos em diferentes profundidades do solo, referentes aos diversos tratamentos estudados nos anos agri$1981 / 82$ e 1982/83. 

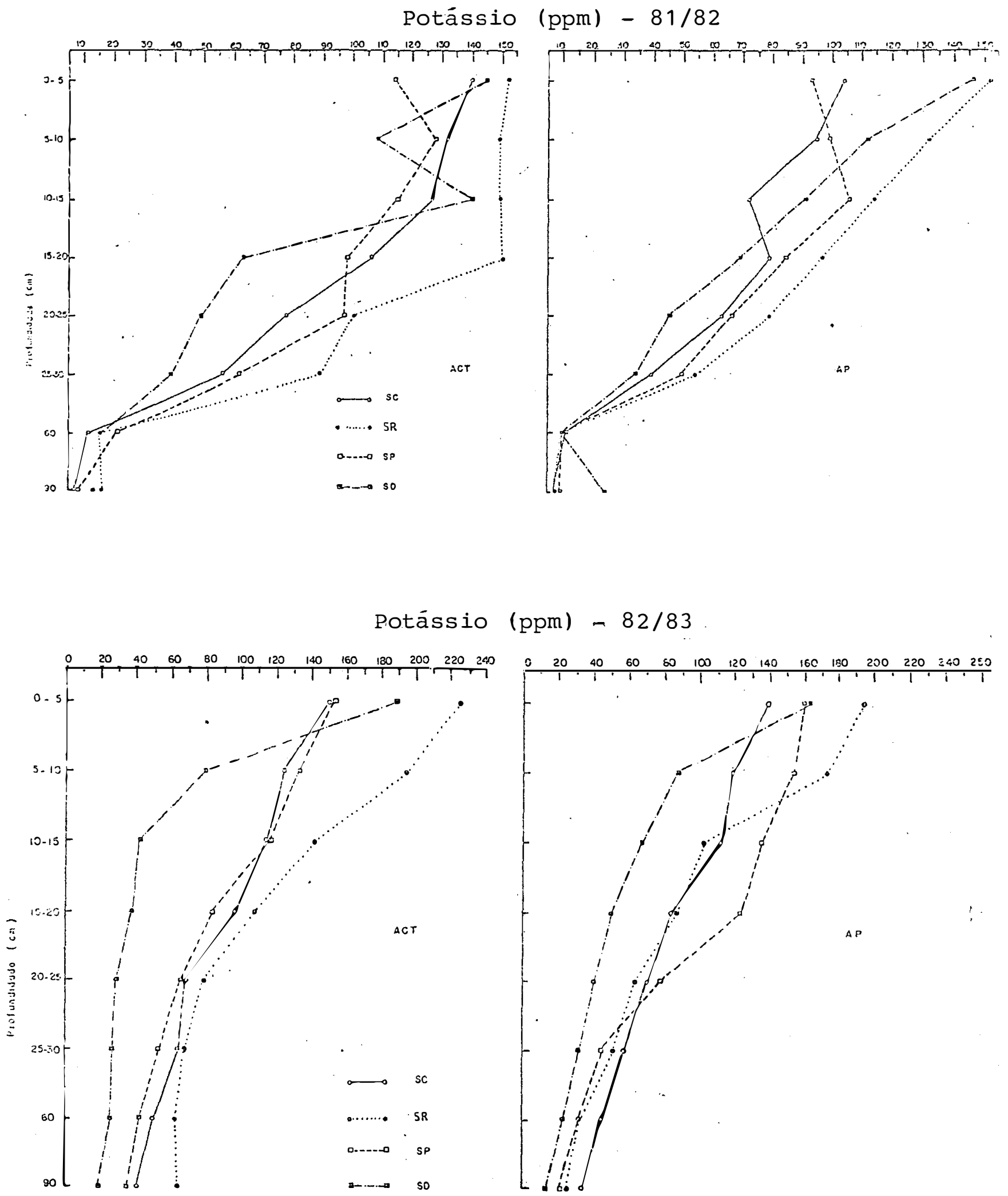

Figura 3 - Valores médios de potássio trocável (ppm), obtidos em diferentes prô fundidades do solo, referentes aos diversos tratamentos estudados nos anos agrícolas 1981/82 e 82/83. 


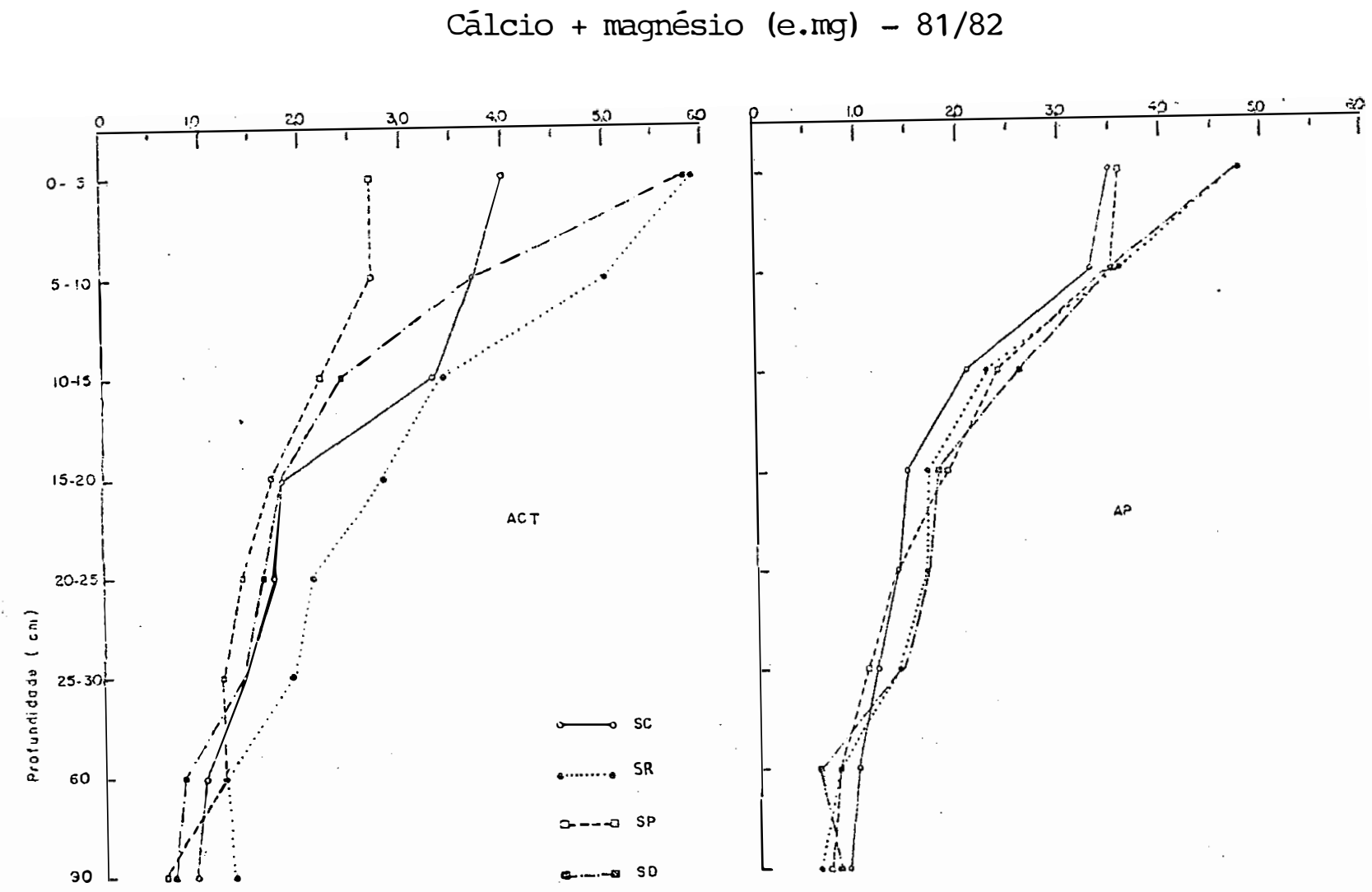

Cálcio + magnésio (e.mg) - 82/83

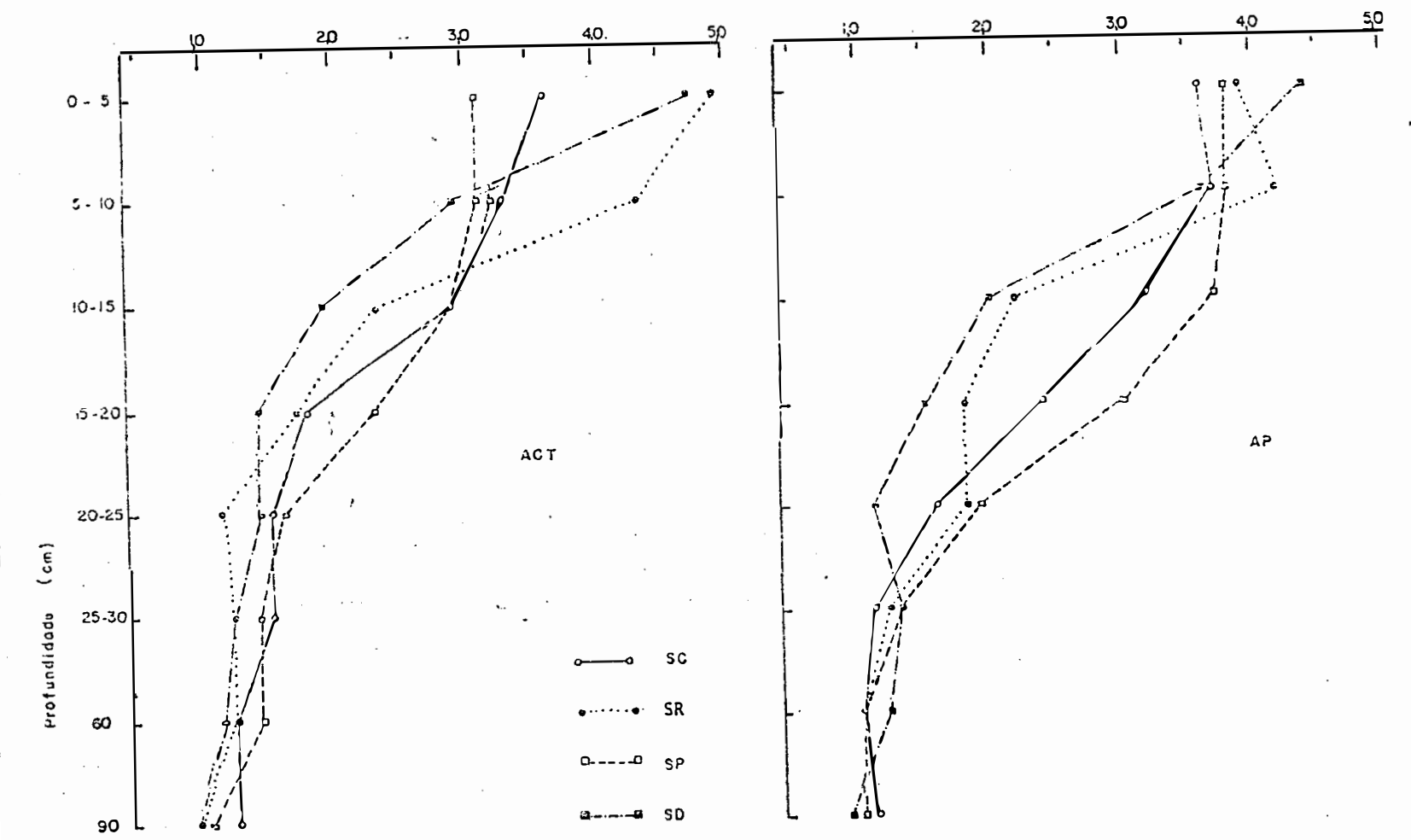

Figura 4 - Valores médios de cálcio + magnésio trocável (e.mg/100 ml de TFSA), obtidos em diferentes profundidades do solo, referentes aos diversos tratamentos estudados nos anos agrícolas 1981/82 e 82/83. 

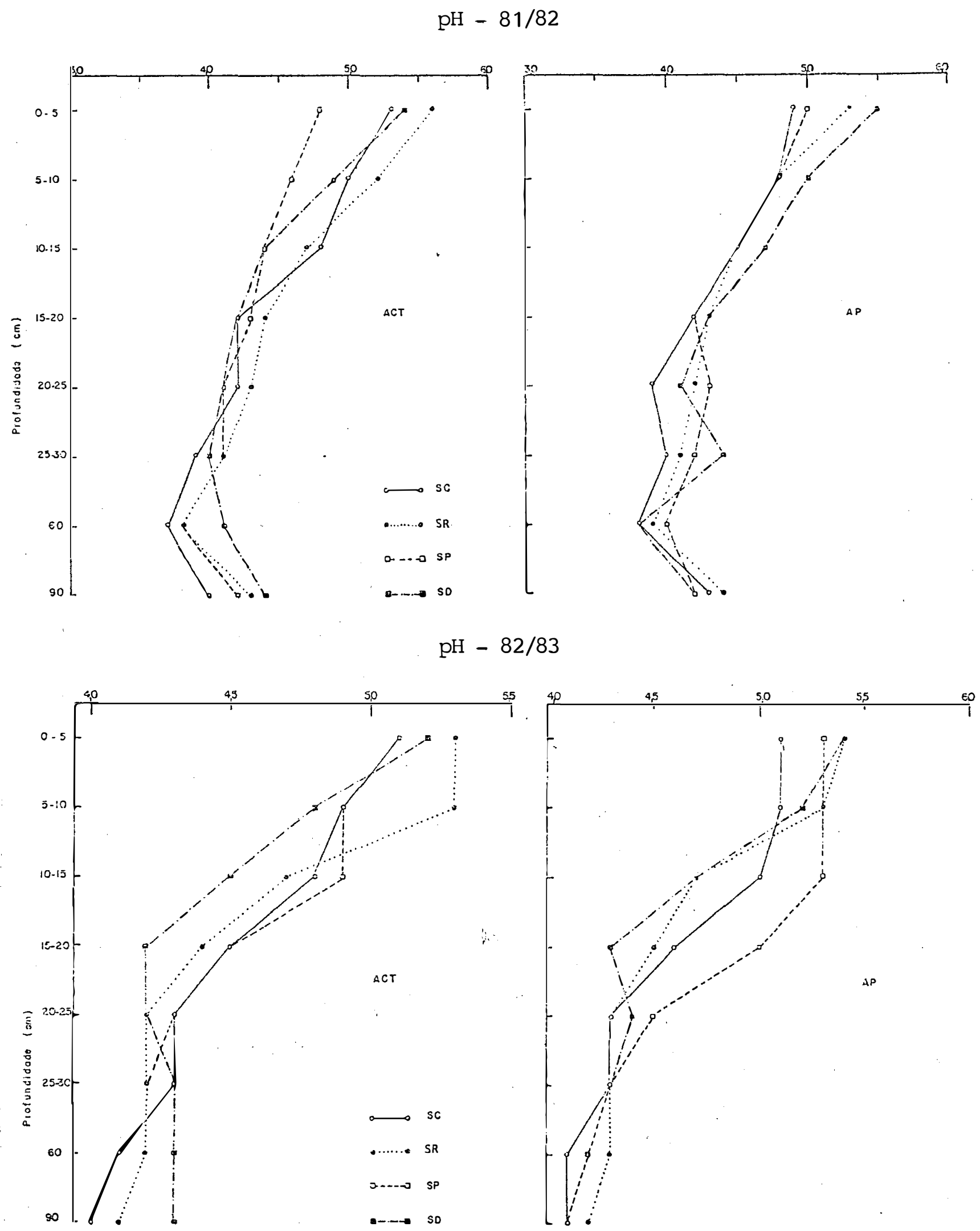

Figura 5 - Valores médios de $\mathrm{pH}$ em $\mathrm{H}_{2} \mathrm{O}$, obtidos em diferentes profundidades do so lo, referentes aos diversos tratamentos estudados nos anos agrícolas $1981 / 82$ e $1982 / 83$. 
C.T.C. (e.mg) - 81/82
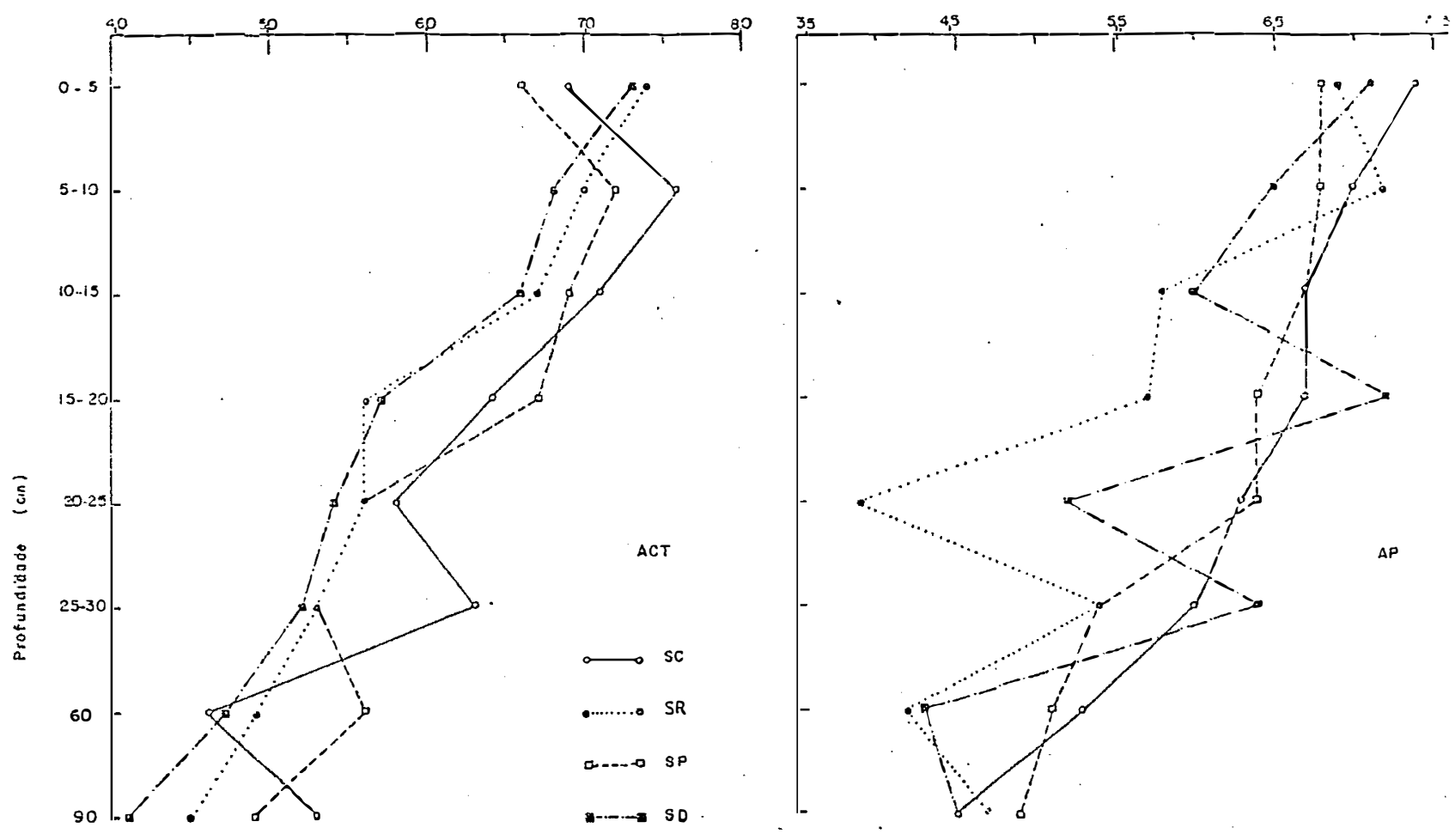

C.T.C. (e.mg) - 82/83
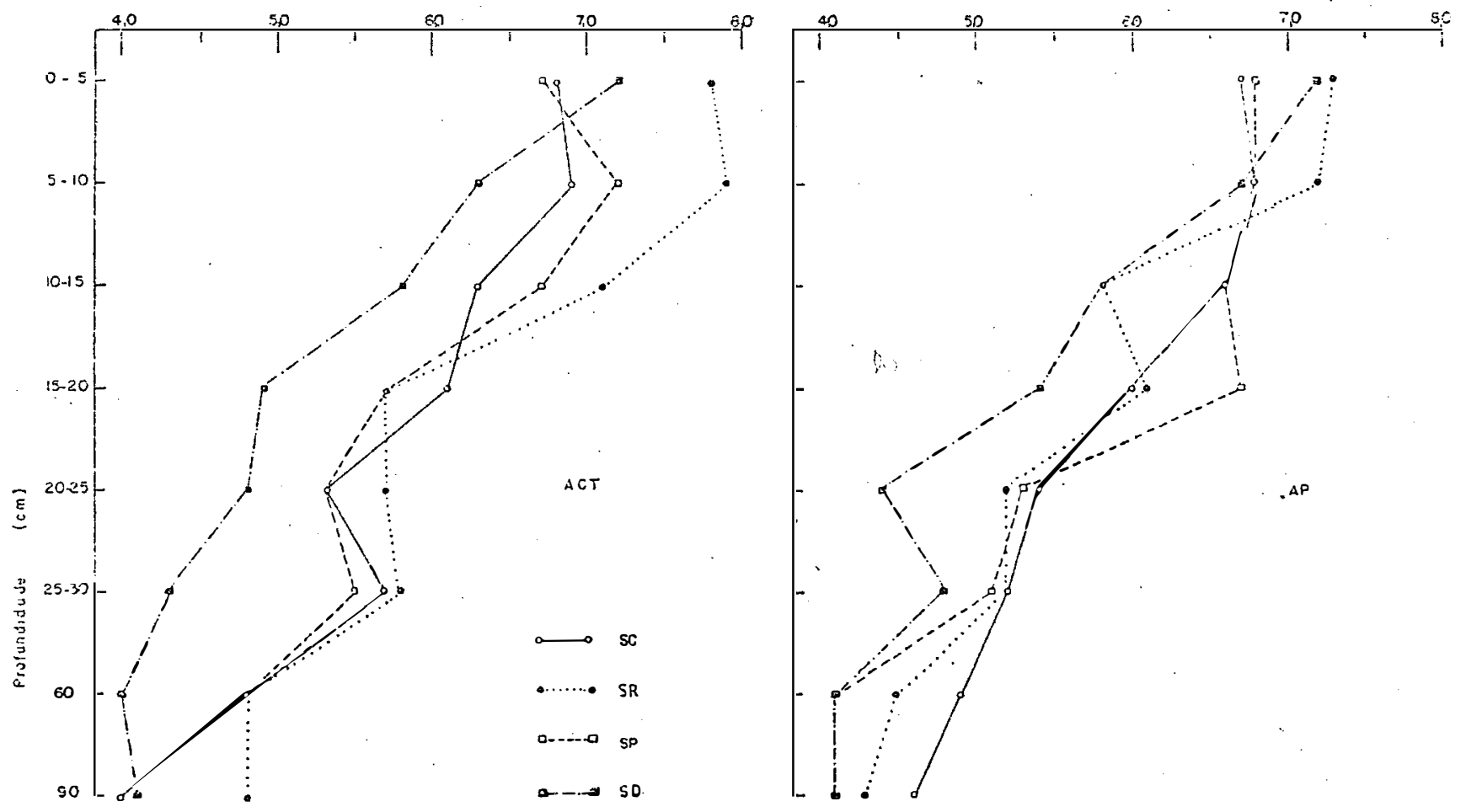

Figura 6 - valores médios de C.T.C. ao pH 7,0 (e.mg/100 ml de TFSA), obtidos em diferentes profundidade do solo, referentes aos diversos tratamentos estudados nos anos agrícolas 1981/82 e 1982/83. 


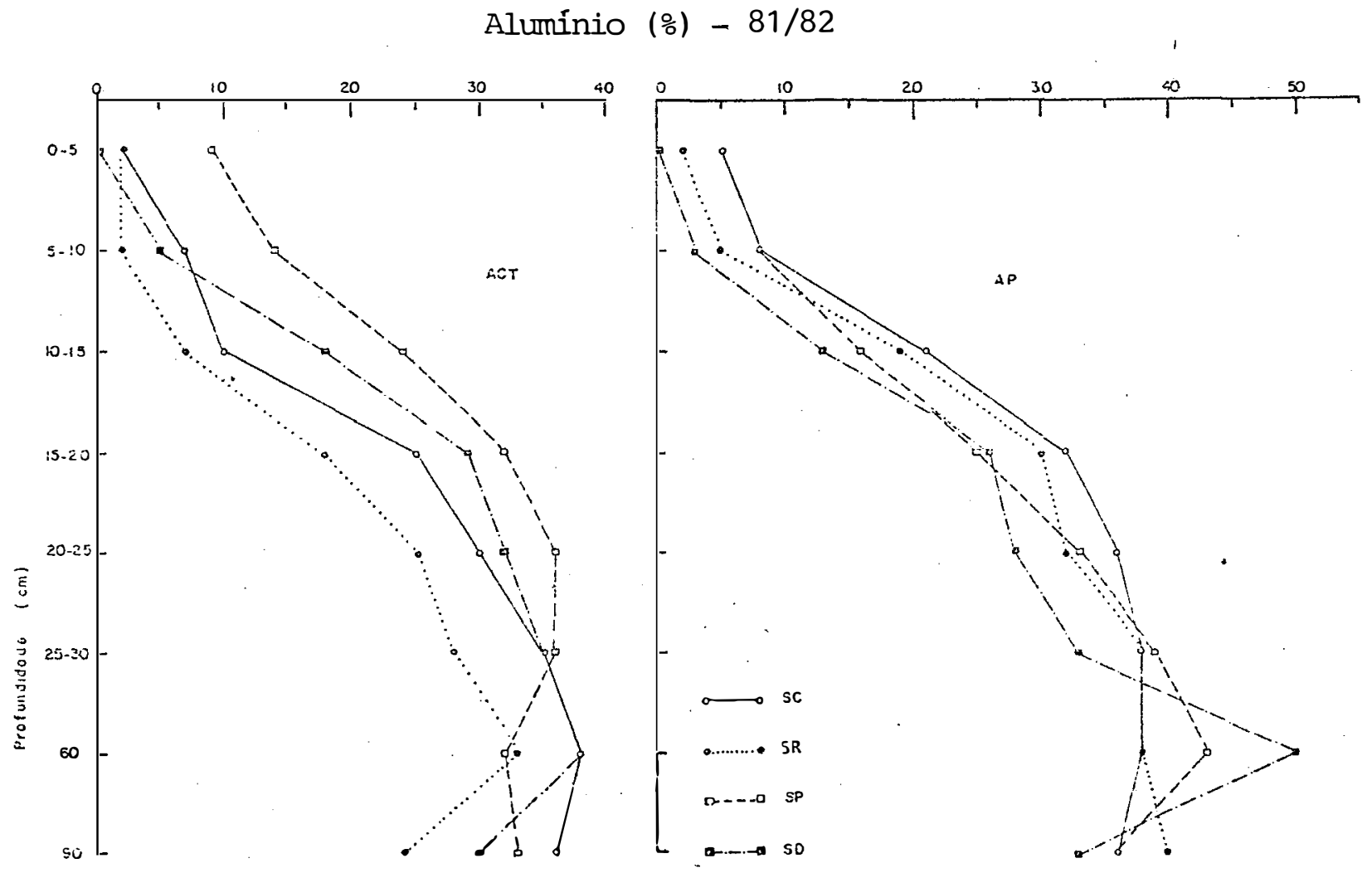

Alumínio (ㅇ) - $82 / 83$

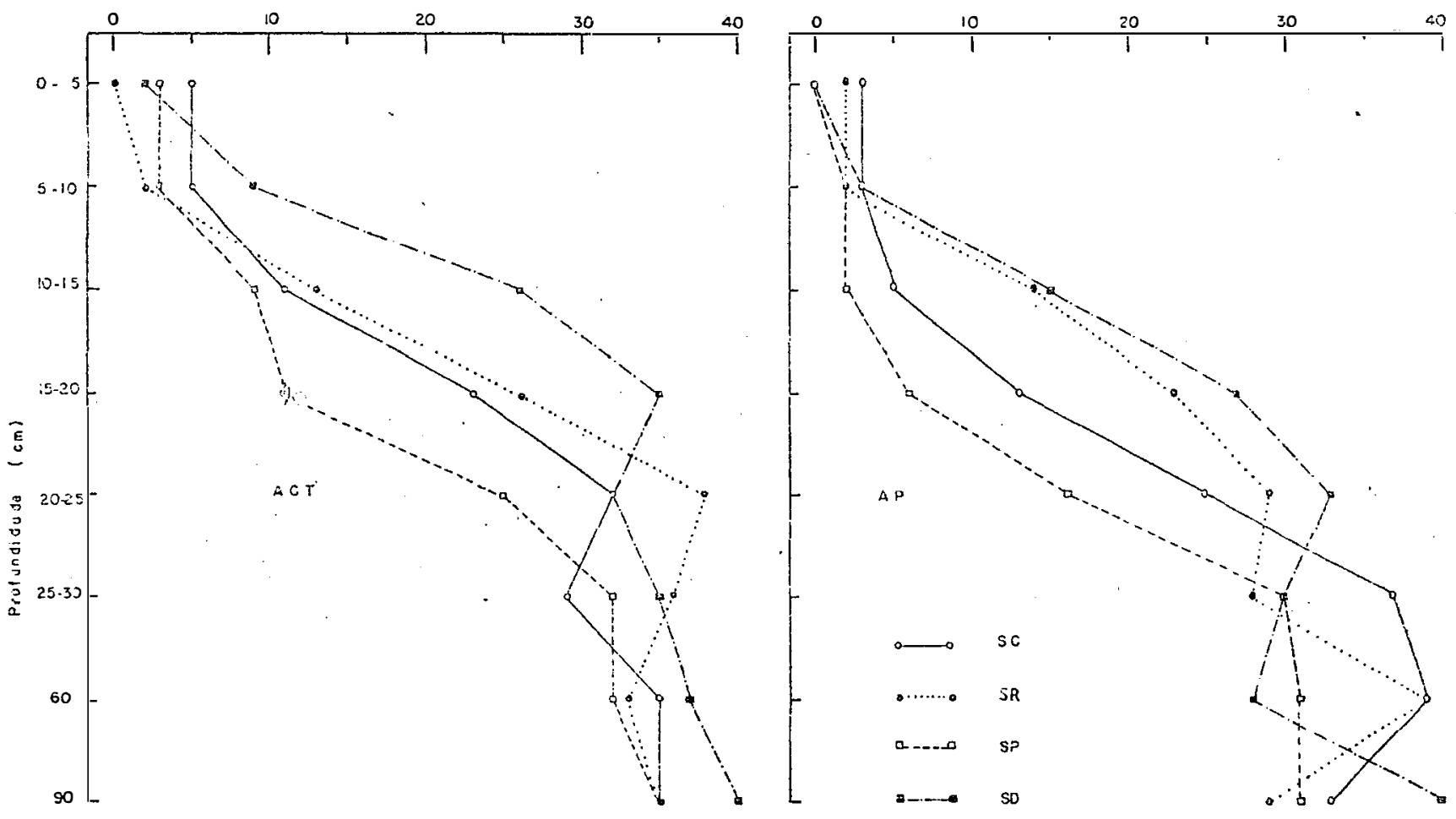

Figura 7 - Valores médios de saturação de alumínio (\%), obtidos em diferentes pro fundidades do solo, referentes aos diversos estudados nos anos agrícolas 1981/82 e 1982/83. 
A Figura 2 mostra os resultados dos teores de fósforo solúvel amostrados a diferentes profundidades do solo. Os altos valores encontrados próximos à superfície, principalmente para o sistema reduzido e semeadura direta, são justificados pela pouca mobilidaảe deste nutriente no solo. Desta maneí ra, em sistemas de prepairo em que o solo é pouco revolvido há uma tendēncia ao maior acúmulo de fósforo solúvel nas camadas mais superficiais (BEZERRA, 1978 e CENTURION et alii, 1982). Embora este fato possa limitar a produtividade da cultura, como indicam os dados da EMBRAPA/CPAC (1980), isto não ocorreu no presente trabalho, possivelmente em razão da soja não ter enfrentado nenhum período de veranico durante o seu ciclo, como pode ser verificado pelos dados dos Apēndices 1 e 2 .

Na Figura 3 estão indicados os valores médios de potássio trocável para os anos agrícolas 1981/82 e 1982/83. A exemplo do que aconteceu com o fósforo, o potássio tem seus maiores teores na camada de 0 a $5 \mathrm{~cm}$, encontrados nos sistemas reduzido e semeadura direta. Isto contraria os resultados de MUZILLI (1983), obtidos também em Latossolo Vermelho Escuro no Es tado do Paraná. Esta discortância pode ser explicada pela maior precipitação que ocorre no Paraná, resultando assim maior lixị viação do potássio. O autor sugere para este nutriente, critérios de adubação semelhantes aos preconizados para o plantio convencional.

A distribuição e acúmulo de cálcio + magnésio trocáveis são apresentados na Figura 4. Observa-se também uma 
tendência de maior acúmulo desses nutrientes próximos à superfície do solo nos sistemas reduzido e semeadura direta. Isto ocorreu devido ao fato de, no início do ensaio,ter se procedido à cạlagem com incorporação superficial do corretivo no sistema reduzido e sem incorporação do corretivo no sistema de semeadura direta. Efeitos similares foram constatado's por BLEVINS et alii (1978) e MUZILLI (1983).

Verifica-se pela Figura 5 que os valores de $\mathrm{pH}$ nos sistemas reduzido e semeadura direta:se situam em faixas mais $\underline{e}$ levadas na camada superficial do solo $(0$ a $5 \mathrm{~cm})$. Resultados semelhantes foram obtidos por GUEDES et alii (1979) e MUZIILI(1983) para o plantio direto.

A Figura 6 apresenta os valores médios de СтC ao $\mathrm{pH}$ 7,0 para os tratamentos estudados. Constata-se também pa ra este parâmetro a tendência de apresentar maiores valores nos primeiros $10 \mathrm{~cm}$ do solo nos sistemas de preparo reduzido e semea dura direta. Entretanto, na camada de 10 a $20 \mathrm{~cm}$ os maiores vạ lores são atribuídos aos sistemas de preparo convencional e su perpreparo. Isto confirma os resultados obtidos por LAL (1976) em ensaio realiżado na Nigéria.

O sistema de semeadura direta indica uma tendên cia a apresentar menores valoreș médios de saturação de alumí nio nos primeiros $5 \mathrm{~cm}$ do solo, crescendo a partir dai, a niveis superiores aos ocorridos nos demais tratamentos, conforme pode ser visto na Figura 7. Obtendo resultados semelhantes BLEVINS et alii (1978) argumentam que o alto teor de matéria or 
gânica na superfície do solo em sistema de semeadura direta in fluencia os valores do aluminio.

Assim, pode-se generalizar que houve uma tendên cia de maior concentração dos nutrientes nos primeiros 5 ou 10 cm de profundidade para os sistemas em que o solo foi pouco re volviido (SD e SR) e uma distribuição mais uniforme na camada arável (0 a $20 \mathrm{~cm}$ ) para os sistemas de preparo que revolveram o solo (SC e SP). Esses dados concordam com os obtidos por RAMOS e DEDECEK (1975) e LAL (1976).

Apesar dos sistemas de preparo alterar a distrí buição dos nutrientes no solo, pode-se constatar, em todos os tratamentos, que os teores dos mesmos na camada arável, são considerados de médio a alto, segundo GARGANTINI etalii (1972), não limitando portanto o rendimento da cultura da soja.

Visando a constatação dos níveis de alguns micronutrientes nos diversos sistemas de preparo do solo, procedeu - se à coleta de amostras do solo por ocasião da semeadura da soja no ano agrícola 1982/83. A Tabela 3 mostra os resultados obtidos para cobre, ferro, manganês e zinco. Verifici-se que os mesmos estão dentro dos limites considera dos críticos para COX e KAMPRATH (1973), não tendo ocorrido, pois, deficiência destes nutrientes na cultura da soja. 
Tabela 3 - Efeito dos sistemas de preparo do solo nos teores e distribui ção de cobre, ferro, manganês e zinco, obtidos de amostras de solo coletadasantes da semeadura da soja do ano agrícola 1982 / 83.

\begin{tabular}{|c|c|c|c|c|c|}
\hline \multirow{2}{*}{ Tratamento } & \multirow{2}{*}{$\begin{array}{l}\text { Profundi-: } \\
\text { dade }(\mathrm{cm})\end{array}$} & \multicolumn{4}{|c|}{ Micronutriente (ppm) } \\
\hline & & $\mathrm{Cu}$ & $\mathrm{Fe}$ & $\mathrm{Mn}$ & $\mathrm{Zn}$ \\
\hline SC & $\begin{array}{c}0-5 \\
5-10 \\
10-15 \\
15-20 \\
60\end{array}$ & $\begin{array}{l}3,9 \\
4,0 \\
3,9 \\
3,8 \\
3,4\end{array}$ & $\begin{array}{l}110 \\
105 \\
107 \\
112 \\
130\end{array}$ & $\begin{array}{l}89,9 \\
89,4 \\
87,3 \\
89,4 \\
35,0\end{array}$ & $\begin{array}{l}1,5 \\
2,2 \\
2,5 \\
2,5 \\
0,8\end{array}$ \\
\hline SR & $\begin{array}{c}0-5 \\
5-10 \\
10-15 \\
15-20 \\
60\end{array}$ & $\begin{array}{l}3,7 \\
3,6 \\
3,1 \\
3,8 \\
3,2\end{array}$ & $\begin{array}{l}104 \\
105 \\
115 \\
134 \\
124\end{array}$ & $\begin{array}{l}98,1 \\
93,9 \\
84,4 \\
63,4 \\
42,5\end{array}$ & $\begin{array}{l}3,4 \\
3,8 \\
2,1 \\
1,2 \\
0,6\end{array}$ \\
\hline SP & $\begin{array}{c}0-5 \\
5-10 \\
10-15 \\
15-20 \\
60\end{array}$ & $\begin{array}{l}3,7 \\
3,7 \\
3,7 \\
3,5 \\
3,3\end{array}$ & $\begin{array}{l}103 \\
104 \\
107 \\
109 \\
122\end{array}$ & $\begin{array}{l}76,9 \\
80,3 \\
78,4 \\
64,5 \\
28,7\end{array}$ & $\begin{array}{l}2,5 \\
2,9 \\
3,3 \\
2,0 \\
1,0\end{array}$ \\
\hline SD & $\begin{array}{c}0-5 \\
5-10 \\
10-15 \\
15-20 \\
60\end{array}$ & $\begin{array}{l}3,2 \\
3,6 \\
3,7 \\
3,4 \\
3,1\end{array}$ & $\begin{array}{r}87 \\
108 \\
116 \\
130 \\
132\end{array}$ & $\begin{array}{r}97,8 \\
89,4 \\
76,9 \\
55,5 \\
34,6\end{array}$ & $\begin{array}{l}2,8 \\
1,6 \\
0,9 \\
0,7 \\
0,5\end{array}$ \\
\hline
\end{tabular}




\subsection{Análise do tecido foliar}

As Tabelas 4 e 5 apresentam os valores de nitro gênio, fósforo, potássio, cálcio e magnésio do tecido foliar da soja para os tratamentos estudados.

Observa-se que os teores de nitrogênio decresce ram do 19 para o 29 ano agrícola estudado, exceto para o siste ma de semeadura direta. Comparando os sistemas de preparo do solo observa-se que o sistema reduzido e semeadura direta apresentam maiores valores médios de nitrogènio, sugerindouma maior fixação de $\mathrm{N}_{2}$ e níveis mais adequados de matéria orgānica. MALAVOLTA et alii (1974) citam que o teor de nitrogênio do tecido foliar da soja, é adequado se está entre 4,51\% e 5,50\%. Houve portanto, ligeira deficiência em todos os tratamentos, sendo esta mais acentuada nos sistemas de preparo convencional e superpre paro, embora não tenham sido observados sintomas visuais.

Com relação aos teores de fósforo, também constatamise valores mais elevados para os sistemas reduzido e semeadu ra direta. Esses resultados concurdam com os obtidos por WIETHOLTER (1975); isto deve ter ocorrido devido aoyisistema de semeadu ra direta apresentar maior teor de umidade na camada superficial favorecendo a taxa de difusão de fósforo até as raízes, cô mo explicam PHILLIPS et alii (1980). Não houve deficiência deste nutriente em nenhum tratamento, pois, segundo MALAVOLTA et alii (1974), o nível considerado adequado varia de 0,26\% a $0,50 \%$ 
Tabela 4 - Valores de nitrogênio, fósforo, potássio, cálcio e magnésio do tecido foliar da soja, expressos em $\%$, referentes aos tratamen tos utilizados no ano agrícola 1981/82.

\begin{tabular}{|c|c|c|c|c|c|}
\hline \multirow{2}{*}{ Tratamento } & \multicolumn{5}{|c|}{ Nutriente } \\
\hline & $\mathrm{N}^{*}$ & $\mathrm{P}^{*}$ & $K^{*}$ & $\mathrm{Ca} *$ & Mg* \\
\hline $\mathrm{SC}+\mathrm{ACT}$ & 4,49 & 0,30 & 1,84 & 1,01 & 2,30 \\
\hline $\mathrm{SC}+\mathrm{AP}$ & 4,14 & 0,28 & 1,92 & 0,92 & 3,07 \\
\hline média & 4,32 & 0,29 & 1,88 & 0,97 & 2,69 \\
\hline $\mathrm{SR}+\mathrm{ACT}$ & 4,38 & 0,34 & 2,09 & 0,93 & 2,30 \\
\hline $\mathrm{SR}+\mathrm{AP}$ & 4,44 & 0,33 & 1,98 & 0,92 & 2,42 \\
\hline média & 4,41 & 0,34 & 2,04 & 0,93 & 2,36 \\
\hline $\mathrm{SP}+\mathrm{ACT}$ & 4,29 & 0,29 & 1,98 & 0,94 & 2,42 \\
\hline $\mathrm{SP}+\mathrm{AP}$ & 4,30 & 0,27 & 2,03 & 0,99 & 2,22 \\
\hline média & 4,30 & 0,28 & 2,01 & 0,97 & 2,32 \\
\hline $\mathrm{SD}+\mathrm{ACT}$ & 4,32 & 0,29 & 1,76 & 1,03 & 2,30 \\
\hline $\mathrm{SD}+\mathrm{AP}$ & 4,42 & 0,297 & 1,81 & 0,93 & 3,60 \\
\hline média & 4,37 & 0,29 & 1,79 & 0,98 & 2,95 \\
\hline
\end{tabular}

* média de 2 repetições. 
Tabela 5 - Valores de nitrogênio, fósforo, potássio, cálcio e magnésio do tecido foliar da soja, expressos em $\%$, referentes aos tratamen tos utilizados no ano agrícola 1982/83.

Nutriente

\begin{tabular}{|c|c|c|c|c|c|}
\hline \multirow{2}{*}{ Tratamento } & \\
\hline & $\mathrm{N}^{*}$ & $\mathrm{P}^{*}$ & $\mathrm{~K}^{*}$ & $\mathrm{Ca} *$ & Mg* \\
\hline $\mathrm{SC}+\mathrm{ACT}$ & 3,66 & 0,34 & 3,36 & 1,38 & 2,38 \\
\hline $\mathrm{SC}+\mathrm{AP}$ & 3,80 & 0,31 & 3,25 & 1,29 & 3,28 \\
\hline média & 3,73 & 0,33 & 3,31 & 1,34 & 2,83 \\
\hline $\mathrm{SR}+\mathrm{ACT}$ & 4,35 & 0,37 & 3,25 & 1,25 & 2,33 \\
\hline $\mathrm{SR}+\mathrm{AP}$ & 4,21 & 0,31 & 3,61 & 1,22 & 2,48 \\
\hline média & 4,28 & 0,34 & 3,43 & 1,24 & 2,41 \\
\hline $\mathrm{SP}+\mathrm{ACT}$ & 3,24 & 0,33 & 3,19 & 1,50 & 3,20 \\
\hline $\mathrm{SP}+\mathrm{AP}$ & 3,85 & 0,33 & 3,50 & 1,40 & 3,05 \\
\hline média & 3,55 & 0,33 & 3,35 & 1,45 & 3,13 \\
\hline $\mathrm{SD}+\mathrm{ACT}$ & 4,76 & 0,43 & 3,25 & 0,99 & 2,63 \\
\hline $\mathrm{SD}+\mathrm{AP}$ & 4,07 & 0,36 & $=., 28$ & 0,88 & 3,20 \\
\hline média & 4,42 & 0,40 & 3,27 & 0,94 & 2,92 \\
\hline
\end{tabular}

* média de 2 repetiçōes. 
Os valores de cálcio e magnésio obtidos durante o ano agrícola $1982 / 83$ são superiores àqueles obtidos no ano anterior, exceto para o sistema de semeadura direta. Os teores de cálcio estão dentro da faixa ideal 0,36\% a 2,00\% para ' uma boa produção, entretanto os valores de magnésio estão em exces so, pois a faixa adequada é 0,26\% a 1,00\% (MALAVOLTA et alii, $1974)$.

A exemplo do que ocorre com o magnésio, os teores de potássio, no 20 ano estudado, se encontram em excesso. Tal fato não ocorreu no 19 ano agrícola, pois, o teor de potás sio nesta ocasião correspondia aos citados como adequados $(1,71 \%$ a 2,50\%). A absorção em excesso de $M g$ e $K$, principalmente no 29 ano agrícola estudado, talvez seja em decorrência dos efeitos residuais no solo, provocados pela calagem e adubação corretiva realizadas por ocasião do preparo da área para semeadura no 1 ! ano agrícola.

\subsection{Caracteristicas físicas do solo}

A Tabela 6 apresenta os valores de densidade do solo e resistência à penetração oḅtidos para os sistemas de preparo de solo estudados. A densidade do solo, nos dois anos agricolas estudados apresentou valores mais elevados nas camadas superiores e menores na camada inferior $(60$ a $67 \mathrm{~cm})$. Esta corresponde ao horizonte B latossólico que se caracteriza por 
.51.

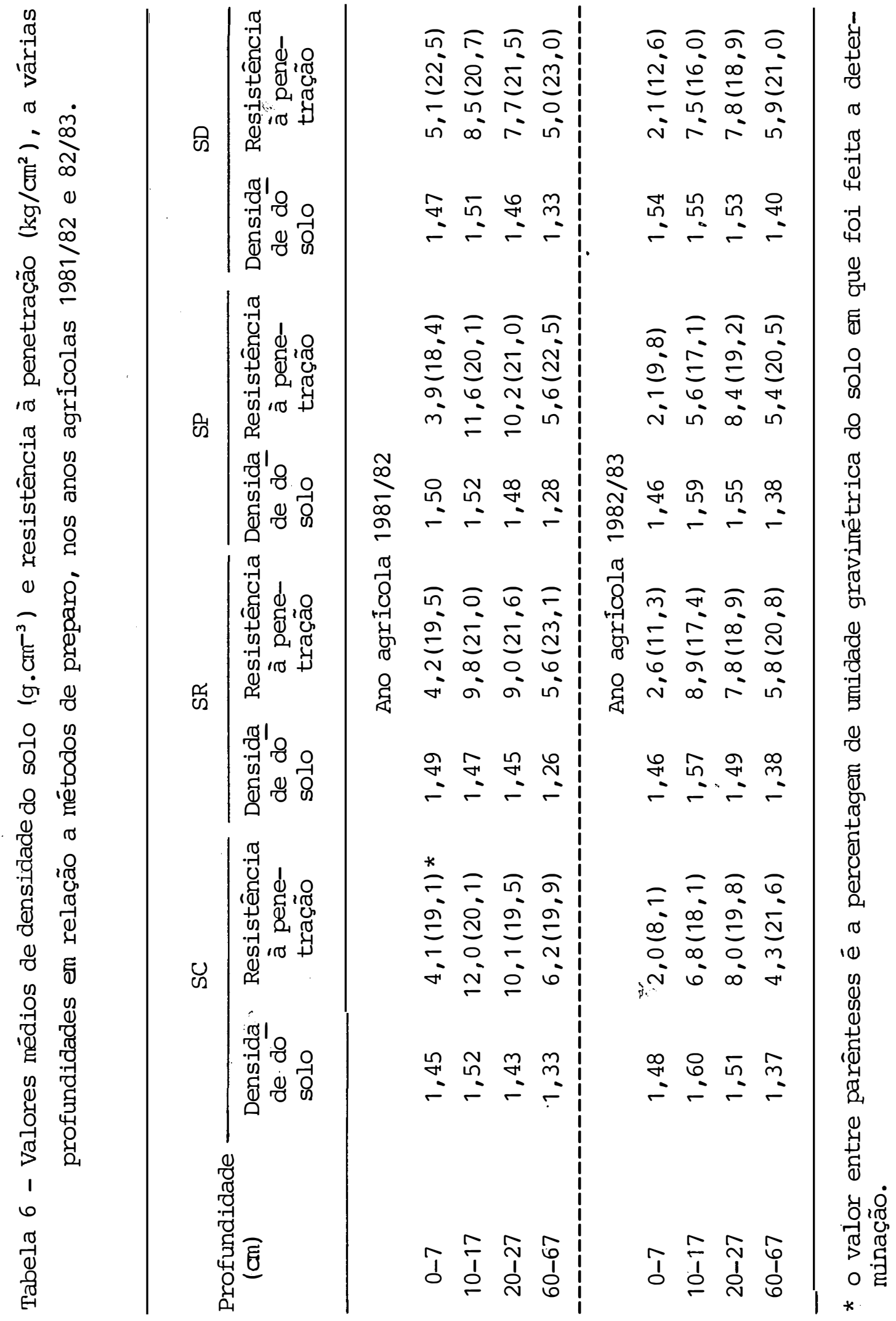


apresentarem carāter esponjoso (COMISSÃO DE SOLOS, 1960). Os valores observados para todos os tratamentos foram bastante se melhantes, confirmando a constatação feita por SACCHI (1982), que também trabalhou com Latossolo Vermelho Escuro. Entretanto; BAEU MER e BAKERMANS (1973) citam que a densidade do solo é menor en sistema de plantio direto, porém neste sistema o solo possui máior homogeneidade estrutural, em termos de espaço poroso, do que quando cultivado no sistema de preparo convencional.

Contudo,entre as camadas do solo avaliadas, per cebe-se uma tendência de alteração na profundidade de 10 a 17 cm, com um aumento da densidade, isto para todos os tratamen tos.

Os valores de resistência do solo à penetração obtidos no ano agrícola 1981/82 também mostram a tendência de formação de uma camada mais compacta na profundidade de 10 a 17 cm, embora os dados de $1982 / 83$ confirmam esta tendência somen- . te para o sistema de preparo reduzido. Embora KAWASAKI et alii (1980) e SHIOYA e FOLLE (1980) encontraram que o grau de compactação, avaliado através da densidade aparente e resistência à penetração, kiue existe no solo de cerrado não é fator de influência direta no desenvolvimento do sistema radicular da soja, isto não ocorreu no presente ensaio, pois, cons tatou-se em todos os tratamentos um desvio das raizes quando encontraram a camada compactada. Também Cintra et alii (1979), citados por SILVA (1980) obtiveram baixa penetração de raízes de soja, quando a resistência à penetração era de $11 \mathrm{~kg} / \mathrm{cm}^{2}$, is 
to para Latossolo Roxo, com teor de umidade na capacidade de campo.

Na Figura 8 são apresentados os valores de macro, microporosidade e porosidade total avaliada. Os mesmos su gerem também a existência de camadas compactadas nas profundida des de 10 a $13 \mathrm{~cm}$ para o sistema reduzido e na profundidade de 20 a $23 \mathrm{~cm}$ para os sistemas de preparo convencional e superpre paro.

Apesar do sistema de semeadura direta também in dicar uma certa tendēncia à compactação, através de uma alta proporção dos microporos em relação aos macroporos, esta não é tão marcante como nos demais tratamentos, o que pode refletir alguma particularidade natural do solo naquele local. Deste mo do fica mais acentuado o efeito do preparo nos sistemas reduzi do, convencional e superpreparo. Neste aspecto os dados concor dam com MACHADO e BRUM. (1978), que obtiveram redução na macroporosidade e porosidade total e aumento da microporosidade em solos intensamente cultivados.

A infiltração acumulada e a velocidade de infil tração de água no solo, conforme mostram as Figuras 9 e 10, in dicam alterações do solo em função do sistema de preparo. Cons tata-se que os maiores valores, após 245 minutos, foram obtidos para o sistema de semeadura direta. Considerando que a infiltração de água reflete as condições físicas do solo, como boa estruturação, porosidade e ausência de camadas compactadas (HILLEL, 1970 e BAUMER e BAKERMANS; 1973), deduz-se que 
.54
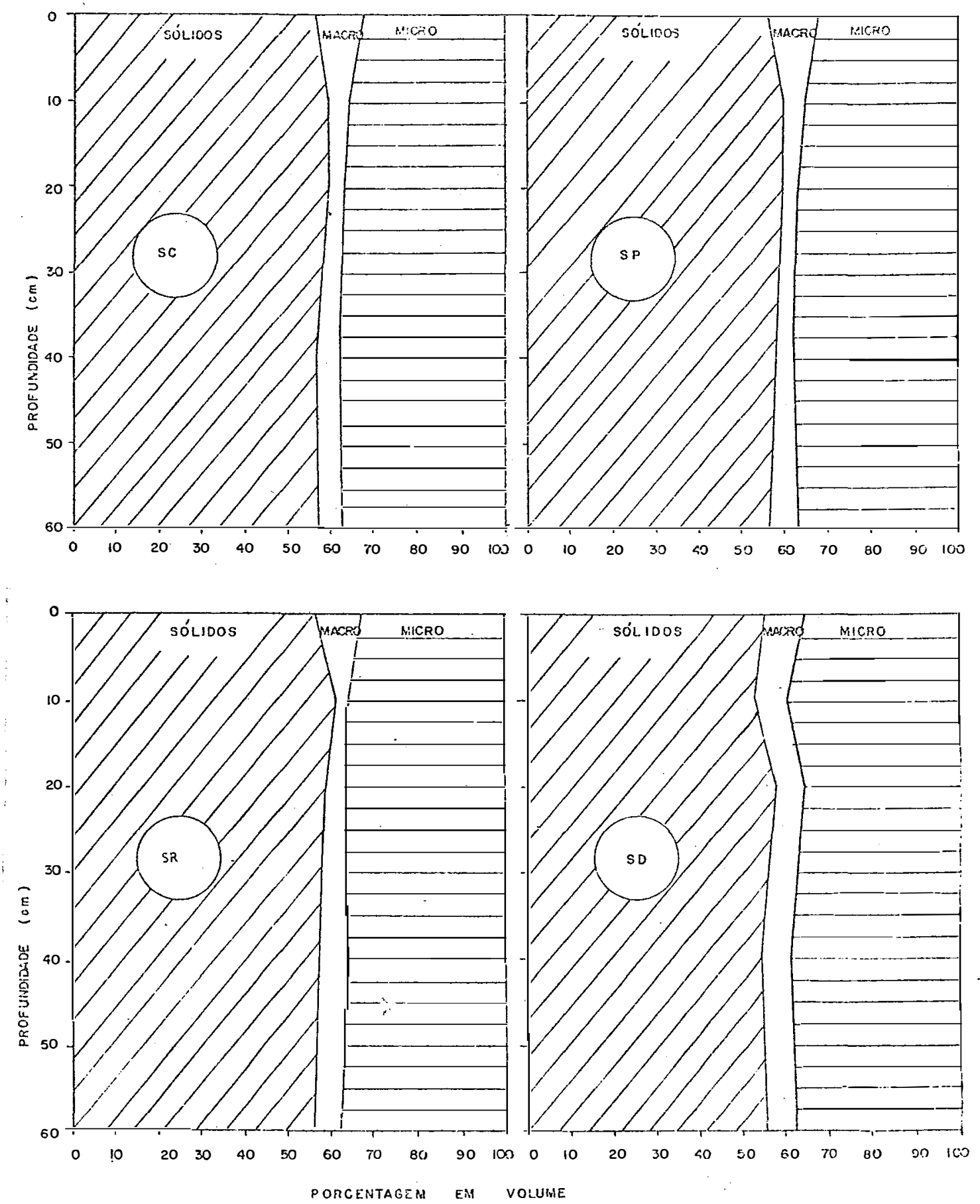

Figura 8 - Valores de macroporosidade, microporosidade e porosidade total avaliada, obtidos em função do preparo do solo, no ano agrícola 1982/83. 
.55 .
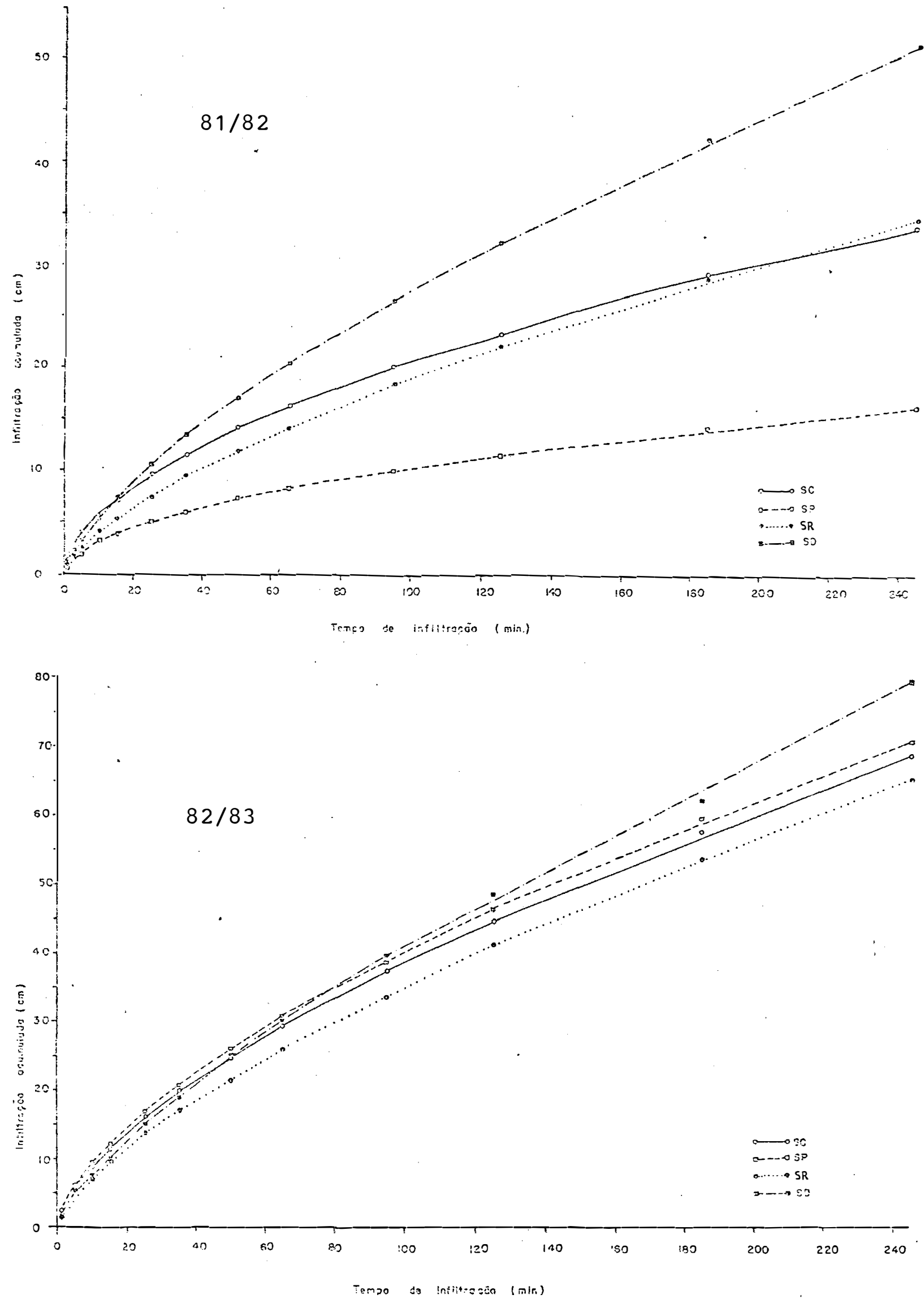

Figura 9 - Valores de infiltração acumulada de água, para os diversos sistemas de preparo do solo, obtidos nos anos agrícolas 1981/82 e 1982/83. 

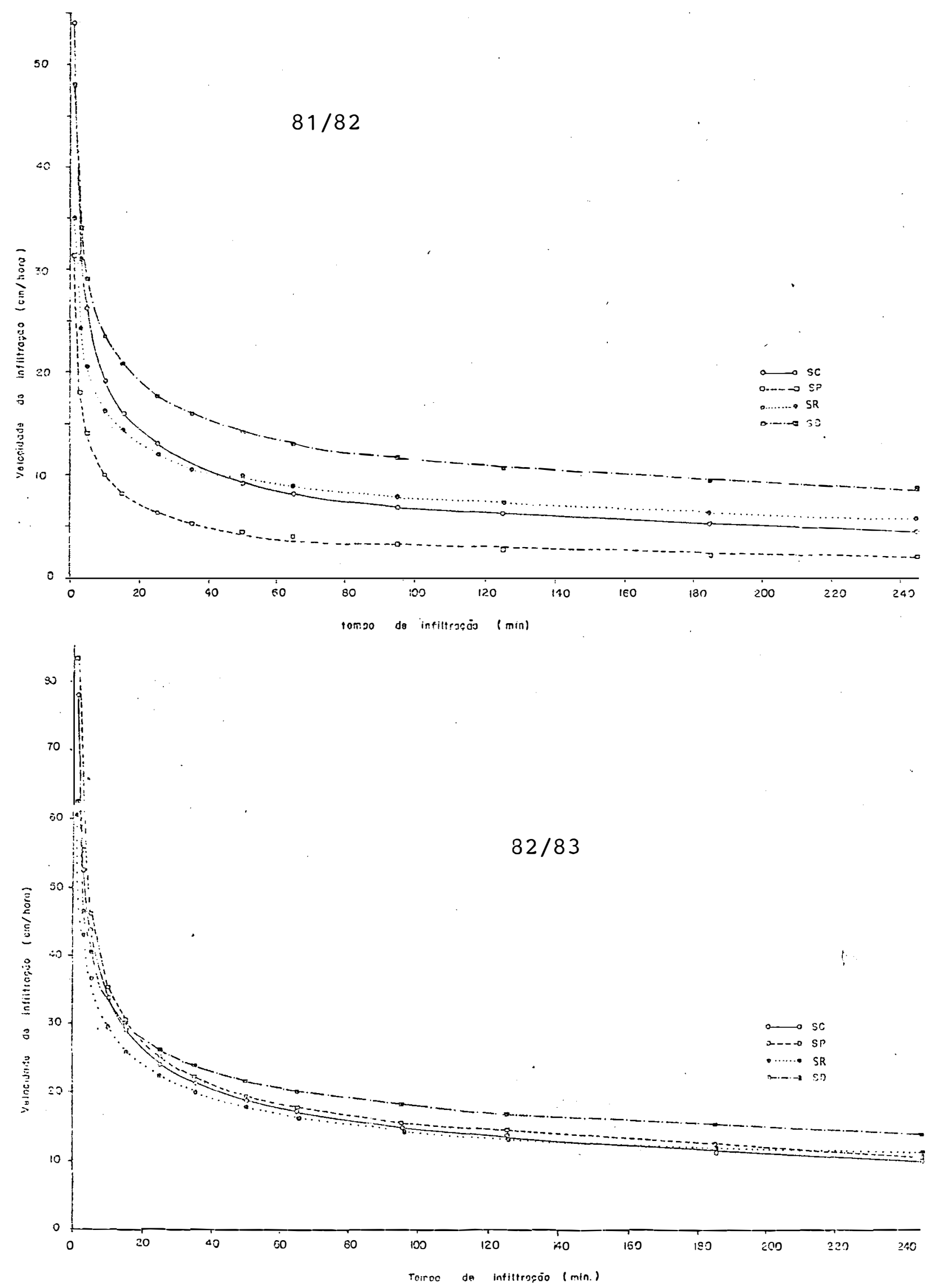

Figura 10 - Valores de velocidade de infiltração de água para os diversos sistemas de preparo, obtidos nos anos agrícolas 1981/82 e 1982/83. 
no solo estudado, estas sofreram modificações acentuadas, em função do sistema de preparo. As modificações, menores no sistema de semeadura direta, se acentuam à medida que se aumenta a intensidade de preparo, atingindo o máximo nos sistemas convencional e superpreparo. Esta diminuição pode trazer inconve nientes como aeração deficiente e aumento do escoamento superficiàl de água,que pode acelerar o carreamento de partícu las do solo e até de agrotóxicos, como observa CAMARGo (1983).

Embora o sistema de semeadura direta tenha apre sentado os maiores valores de velocidade de infiltração bási$\mathrm{ca}, 8,7$ e $14,2 \mathrm{~cm} / \mathrm{h}$ nos anos agricolas $1981 / 82$ e 1982/83, respectivamente, eștes valores estão aquém daqueles obtidos por WOLF (1975). Este autor encontrou para Latossolo Vermelho Escuro de cerrado valores entre 17 e $22 \mathrm{~cm} / \mathrm{h}$.

As Figuras 11 a 15 apresentam as curvas de retenção de umidade para os diversos sistemas de preparo do so10. Pelas Figuras 11 e 12 observa-se que os sistemas de preparo seduzido e principalmente de semeadura direta apresentam valo res mais elevados de umidade gravimétrica em relação aos demais tratamentos. Isto ocorre em virtude do acúmulo de matériai orgânica nestes sistemas, pois, a retenção de umidade a baixas tensões está mais relacionada ao teor de matéria orgânica (REE VE et alii, 1973) e consequentemente à estrutura do solo (REICHARDT, 1975). Para as profundidades de 20 a $23 \mathrm{~cm}$ e 40 a 43 $\mathrm{Cm}$, apresentados respectivamente nas Figuras 13 e 14, observa -se maior retenção de água nos sistemas reduzido e de semeadura 


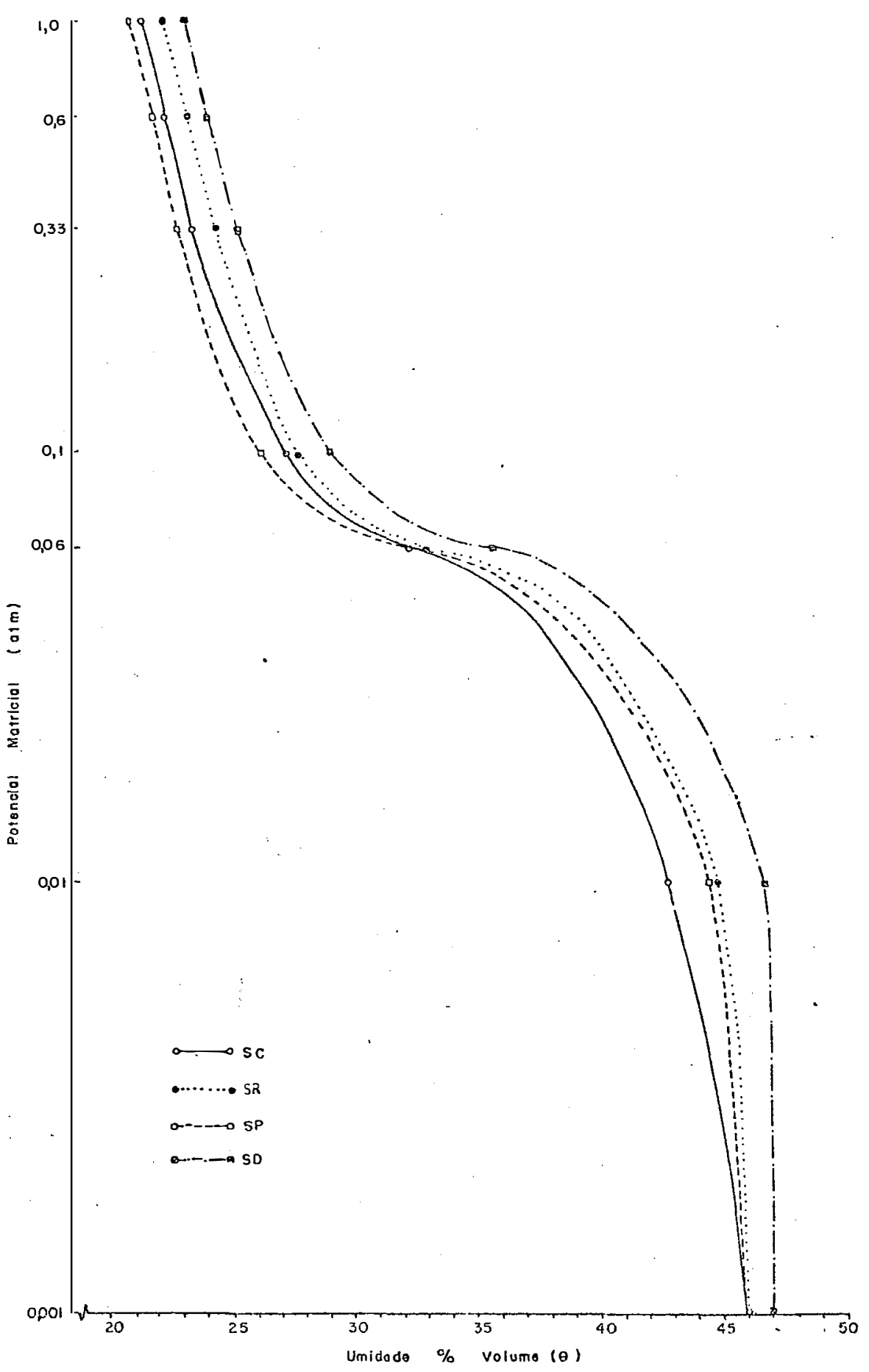

Figura 11 - Curvas de retenção de umidade obtidas na profundidade de 0 a $3 \mathrm{~cm}$, para os diversos sistemas de preparo do solo estudados no ano agrí cola 1982/83. 


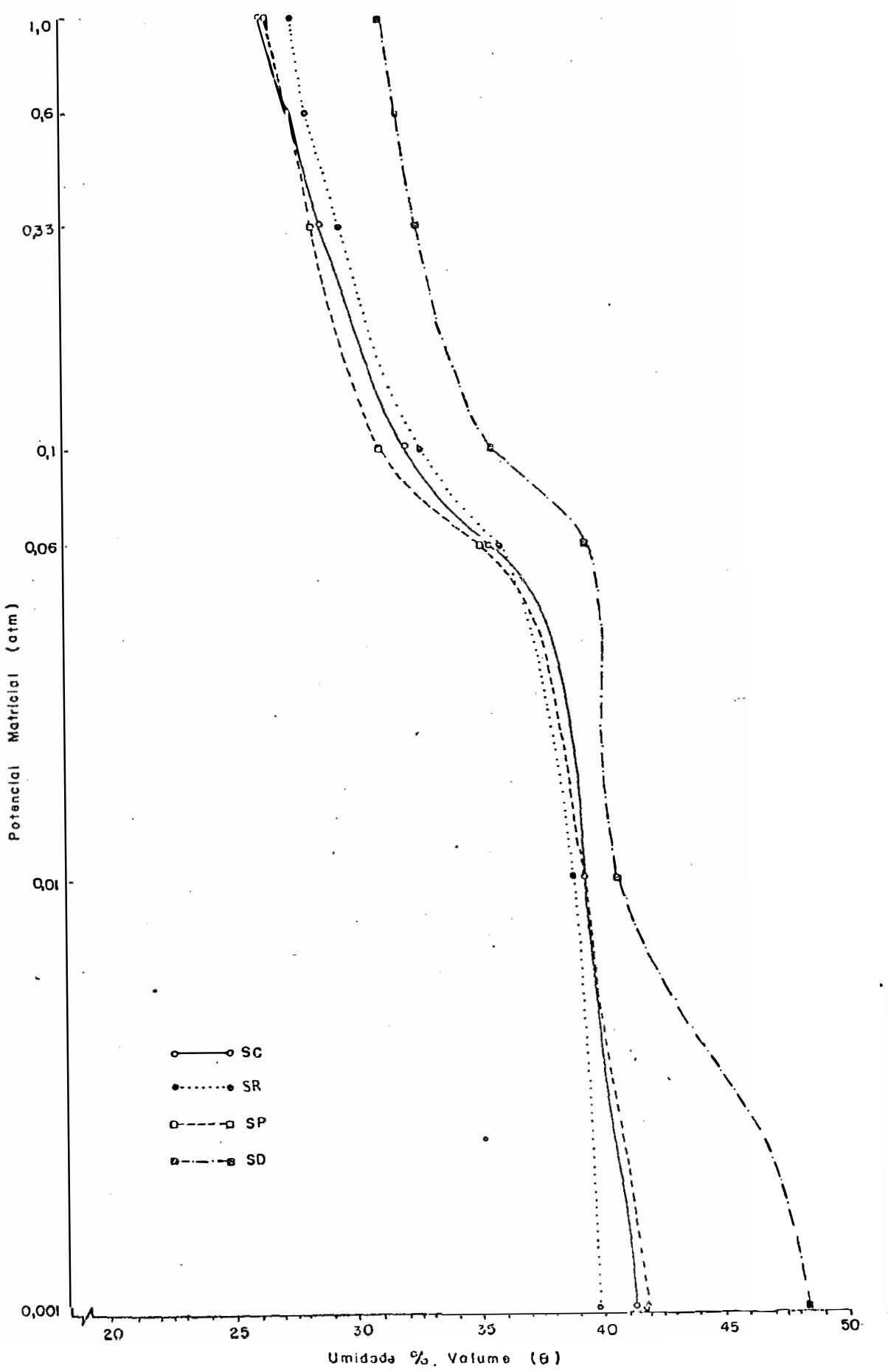

Figura 12 - Curvas de retenção de umidade obtidas na profundidade de 10 a $13 \mathrm{~cm}$, para os diversos sistemas de preparo do solo estudados no ano agríco la $1982 / 83$. 
.60 .

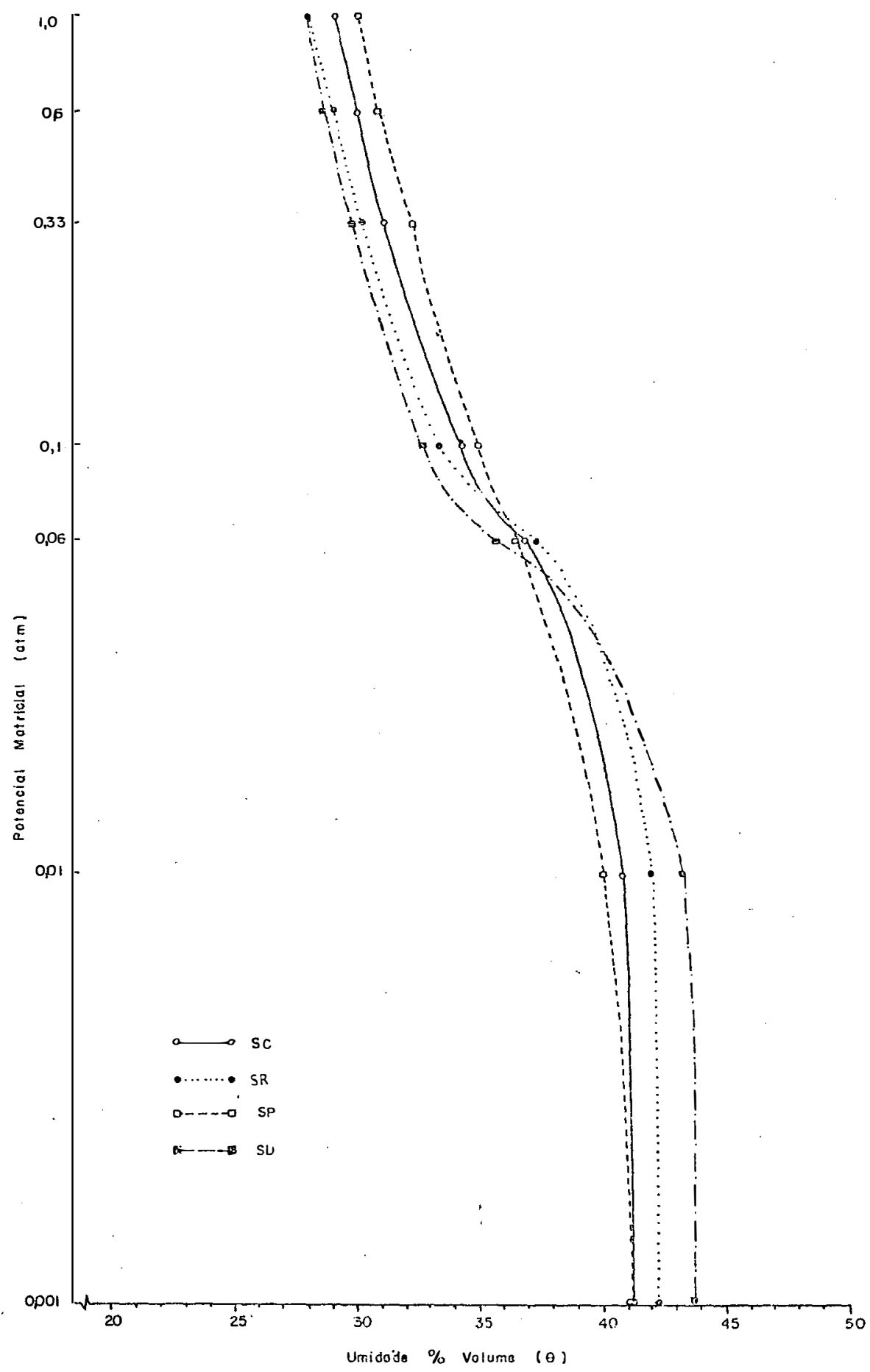

Figura 13 - Curvas de retenção de umidade obtidas na profundidade de 20 a $23 \mathrm{~cm}$, para os diversos sistemas de preparo do solo estudados no ano agríco la $1982 / 83$. 


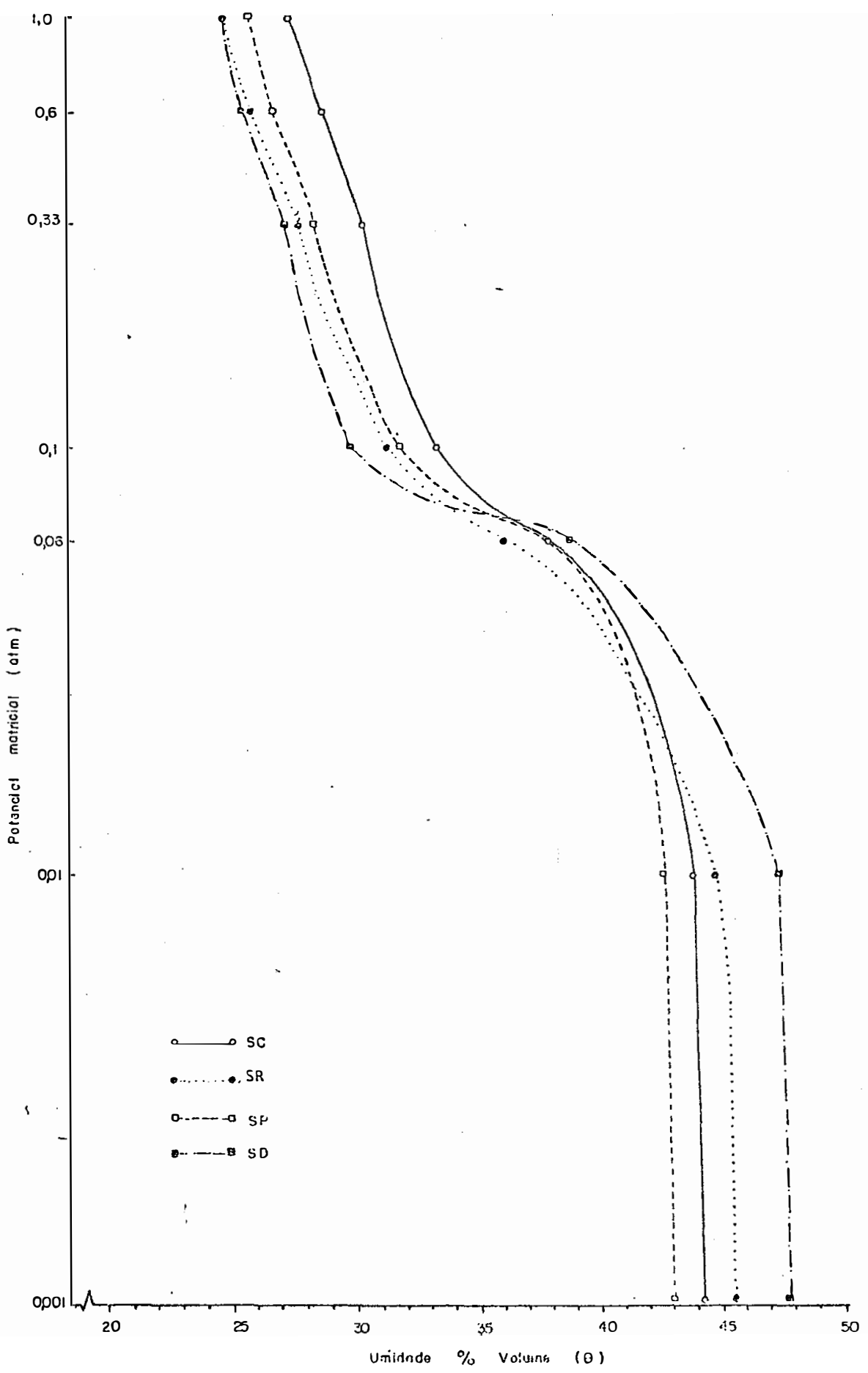

Figura 14 - Curvas de retenção de umidade obtidas na profundidade de 40 a 43 cm, para os diversos sistemas de preparo do solo estudados no ano agríco la $1982 / 83$. 


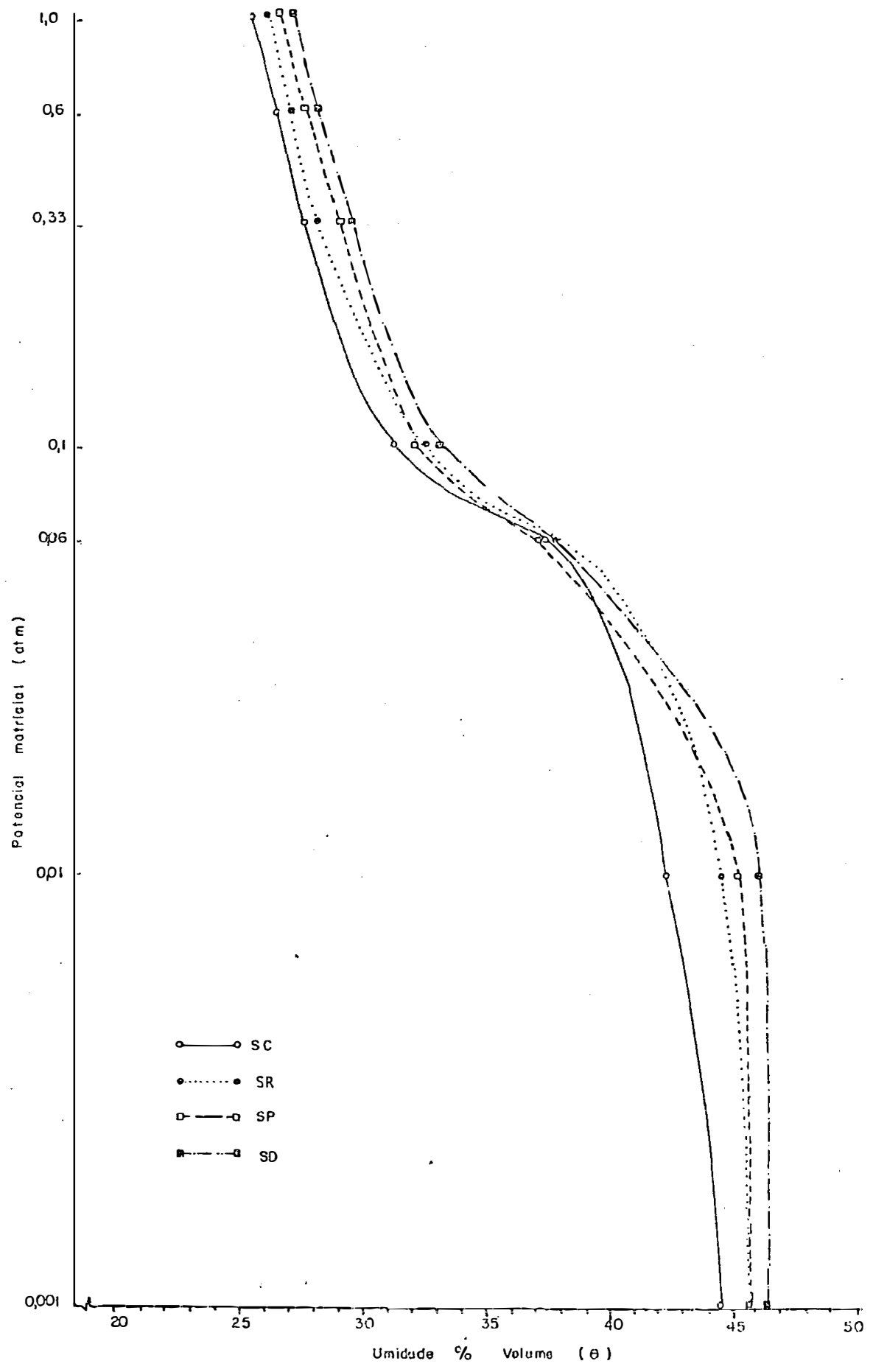

Figura 15 - Curvas de retenção de umidade obtidas na profundidade de 60 a $63 \mathrm{~cm}$, para os diversos sistemas de preparo do solo estudados no ano agríco la $1982 / 83$. 
direta, isto para baixas sucções. Entretanto para as sucções mais elevadas, dentre os limites estudados $(0,001$ - 1 atm), verifica-se maior retenção de āgua para os sistemas de superpreparo e convencional. Tal fato está relacionado com os efeitos da compactação ocorrida nos sistemas convencional e superprepa ro, pois segundo HILLEL (1970), camadas compactadas, por apresentarem maior volume de microporos, retêm mais água.

Este aspecto reflete nos valores de umidade do solo obtidos através das curvas de retenção de água que sãomos trados na Figura 16. Desta forma, quando o solo se apresenta com elevado teor de umidade volumétrica, como ocorreu no períodode 25 a 35 dias após a semeadura, constatam-se valores mais elevados para os sistemas reduzido e semeadura direta, que propiciam me lhores condições de estrutura ao solo. Entretanto, nos períodos de menores precipitações, quando o potencial matricial da água do solo está mais na dependência de forças de adsorção (REI CHARDT, 1975), verificam-se valores mais elevados de umidade do solo nos sistemas convencional e superpreparo. Os valores de $\underline{u}$ midade volumétrica do solo obtidos na profundidade de 20 a 23 cm, apresentados i.a Figura 16, visualizam bem este aspecto. Estes resultados vêm confirmar as hipóteses levantadas anteriormente a respeito da formação de camada compactada nesta profundidade para os sistemas de preparo convencional e superpreparo. Deste modo, como relata CAMARGO (1983), esta camada compactada aumenta a quantidade de água retida na fai xa de disponibilidade para as plantas. Entretanto,esta disponi 

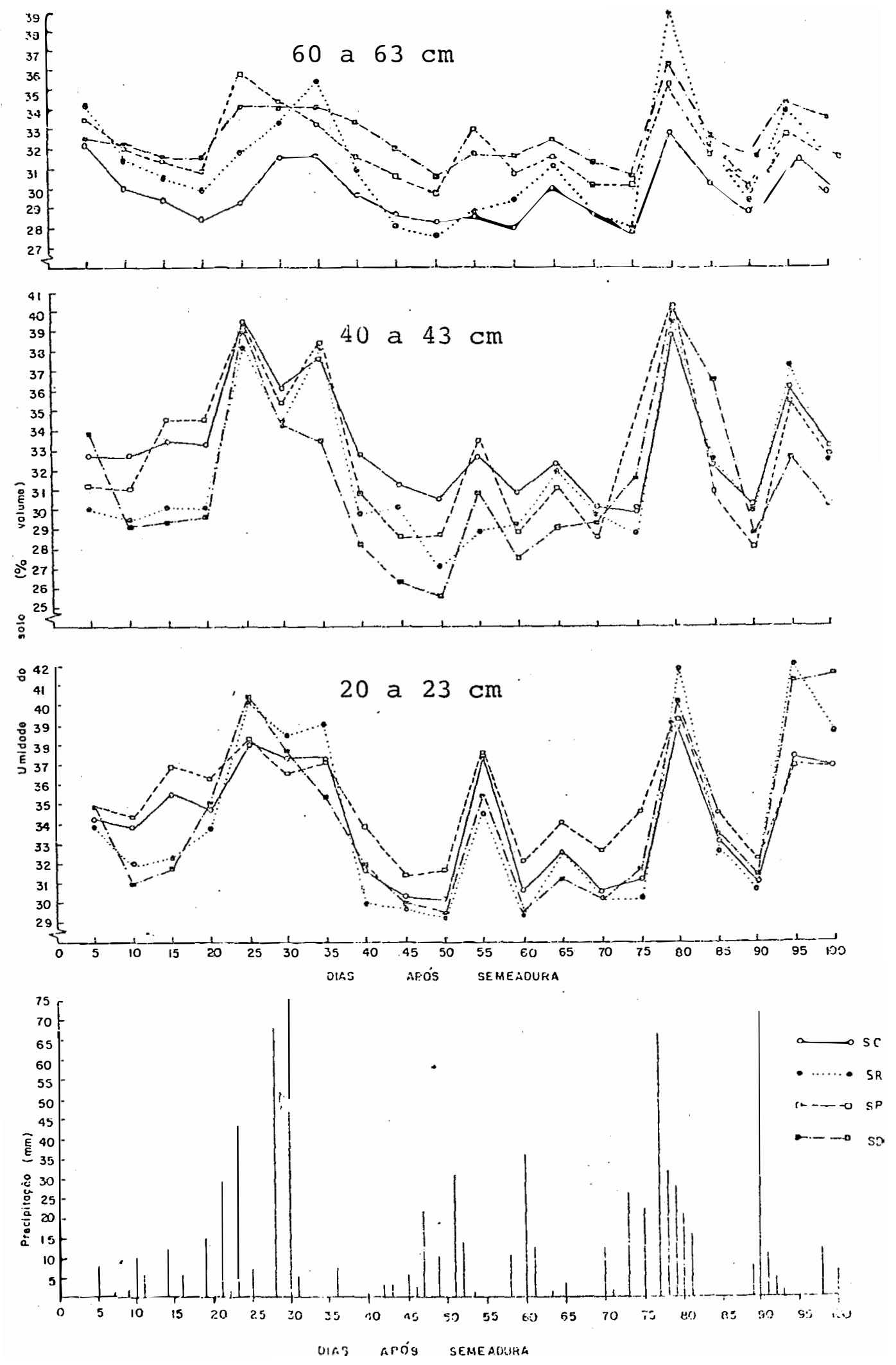

Figura 16 - Valores de precipitação e umidade do solo, para as profundidade de 20 a $23 \mathrm{~cm}, 40$ a $43 \mathrm{~cm}$ e 60 a $63 \mathrm{~cm}$, obtidos durante o ciclo da soja, cultivada no ano agrícola 1982/83. 
bilidade deve ser interpretada concomitantemente com a deficiência de aeração e a resistência mecânica do solo.

Aumenta a importância dos resultados obtidos, o fato de que em tais solos, bem agregados, como argumentam UE HARA e KENG (1975), a água pode ser retida em poros interagrega dos de maiores ou’ menores dimensões. Estes autores consideram como importante, do ponto de vista agronômico, somente o conteúdo de água retido a tensc̄es de zero a dois bares. A água retida acima deste limite não é facilmente disponível para as plantas, devido limitações impostas por sua baixa mobilidade.

Também WOLF (1975) e DEMATTÊ (1980) relatam que a maior parte da água, em solos argilosos de cerrado, é retida em tensões de até $1 \mathrm{~atm}$. Estes solos se comportam como areno sos no tocante às propriedades físico-hídricas (LOPES, 1983) .

Desta forma, fica clara a importância do manejo que o solo deve receber, pois isto reflete principalmente na distribuição dos tamanhos de poros e agregados, afetando o comporta mento da água nestes solos, como demonstram os resultados do presente trabalho.

\subsection{Caracteristicas agronōmicas}

As Tabelas 7 e 8 apresentam os resultados referentes às características agronômicas estudadàs na cultura da soja, no 19 e 20 ano de cultivo.

Verifica-se que o "stand" foi uma das caracte - 
rísticas mais modificadas em função do preparo do solo, apresentando diferenças significativas (Tabela 9). No 19 ano de cultivo o "stand" nos sistemas convencional, reduzido superpre paro foi prejudicado devido às elevadas precipitações que ocor reram após a semeadura, as quais provocaram a formação de cros ta superficial. Efeitos similares foram constatados por OHMURA e HOWELL (1960).

O baixo "stand" apresentado pelos sistemas que tiveram o solo revolvido ao ser preparado para o 29 ano de cultivo, é atribuído à ocorrência de um período de estiagem logo após a semeadura. No sistema de semeadura direta a cobertura de resíduos propiciou melhor germinação, como também verificou RA $\operatorname{MOS}(1981)$.

O sistema de semeadura direta também apresentou valores médios mais elevados de altura de planta e inserção da primeira vagem. As Tabelas 10 e 11 mostram as diferenças estatísticas significativas entre este sistema e os demais. Os resultados confirmam os dados da literatura, uma vez que altura de plantas (ROSELEM et alii, 1983) e altura de inserção da prí meira vagem (QUEIROZ et alii, 1979) aumentam com a população . Porém os valores da altura de inserção obtidos para todos os tratamentos é inferior aos $13 \mathrm{~cm}$ considerados como o limite mínimo ideal para a colheita mecānica (QUEIROZ et alii, 1981). Desta forma, as maiores perdas ocorreram nos sistemas reduzido, convencional e de superpreparo. 
das constatou-se diferenças estatísticas significativas com re lação às adubações empregadas, apenas dentro do sistema de pre paro reduzido do solo, onde a adubação de correção total propiciou um maior crescimento da planta em relação à adubação parcelada (Tabela 12).

Assim, no presente ensaio a adubáção praticamente não alterou significativamente as características agronômicas estudadas, inclusive o rendimento de grãos, indicando que havia no solo um nível adequado de nutrientes, pois como sugerem BATAGLIA e MASCARENHAS (1977), para um determinado cultivar, a exigência em nutrientes deve estar relacionaăa à produção que se obtém.

Os efeitos dos sistemas de preparo do solo na cultura da soja pode também ser constatados através dos maiores rendimen tos de grãos obtidos nos dois anos de cultivo no sistema de se meadura direta. Embora este sistema apresente valores superiores aos demais, estatisticamente somente difere do sistema reduzido, isto para o 19 ano de cultivo (Tabela 13). Por outro lado, no 29 ano de cultivo, somente o sistema convencional não difere estatisticamente em rendimento de grãos do sistema de semeadura direta.

Embora o sistema de semeadura direta tenha propiciado as maiores produtividades, seus valores obtidos para o peso de 100 grãos são estatisticamente inferiores aos demais tratamentos, como demonstram os dados da Tabela 14. Isto está associado à maior população de plantas ("stand") obtida no sis 
tema de semeadura direta, confirmando os resultados de BARNI et alii (1982), que obtiveram que o peso de 100 grãos tende a reduzir com o aumento da população de plantas.

Os efeitos dos tratamentos na distribuição do sistema radicular da soja, da superfície até $20 \mathrm{~cm}$ de profundi dade, são mostrados na Tabela 15. Observa-se, a exemp'lo do que constatou BENEZ et alii (1979), em estudo realizado também em Latossolo Vermelho Escuro, que os menores valores de peso seco são atribuídos ao sistema de semeadura direta.

A densidade de distribuição das raízes, expressa em porcentagem de peso seco/planta, apresentada na Tabela 16, revela que no sistema de semeadura direta estas secconcentram na camada mais superficial do solo $(0-5 \mathrm{~cm})$. Embora neste as pecto exista concordância com RAMOS e DEDECEK (1975), não se pode afirmar para o presente trabalho quesaquele parāmetro foi o respon sável pelas maiores produções obtidas por esse tratamento. Os efeitos das camadas compactadas constatadas através dos parâmetros físicos analisados, são ilustrados pela Figura 17. Observa-se que as raizes da soja sofrem um desvio quando encontram esta camada. Efeitos mais acentuadis foram obtidos para os sistemas reduzido, convencional e de superpreparo do solo, embora constatado também para a semeadura direta.

Entretanto estas plantas, como explica CAMARGO (1983), vivendo em solo com alta resistência só sofrerá quando o suprimento de água e nutrientes for escasso. Embora essa es- 
cassez possa ocorrer em áreas de cerrado, devido a baixa fertilidade natural, baixa retenção de umidade pelo solo e constantes veranicos, no presente ensaio a mesma não foi observada. Portanto, dentre as caracteristicas analisadas, pode-se atribuir ao "stand" os principais efeitos no maior ren dimento de grãos constatado no sistema de semeadura direta, pois, como afirmam QUEIROZ et alii (1979) e BARNI e BERGAMASCHI (1981) a população de $400 \mathrm{mil}$ plantas por hectare propicia melhores produções de soja. 
Tabela 7 - Efeitos de sistemas de preparo do solo e modos de adubação em algumas características agronômicas da soja, no ano agrícola $1981 / 82$.

\begin{tabular}{|c|c|c|c|c|c|}
\hline Tratamento & $\begin{array}{l}\text { Rendimento } \\
\text { grãos* } \\
\text { (kg/ha) }\end{array}$ & $\begin{array}{c}\text { Peso de } 100 \\
\text { grãos* } \\
\text { (g) }\end{array}$ & $\begin{array}{c}\text { Altura } \\
\text { de } \\
\text { planta** } \\
\text { (cm) }\end{array}$ & $\begin{array}{c}\text { Inserção } \\
\text { da 1å } \\
\text { vagem** } \\
\text { (cm) }\end{array}$ & $\begin{array}{c}\text { "stand"** } \\
\text { (no plan- } \\
\text { tas/m) }\end{array}$ \\
\hline $\mathrm{SC}+\mathrm{ACT}$ & $1200,2 \mathrm{bc}$ & $15,06 a$ & 47,0 & 7,3 & 8,8 \\
\hline $\mathrm{SC}+\mathrm{AP}$ & $1220,4 \mathrm{bc}$ & $13,70 \mathrm{ab}$ & 43,7 & 6,0 & 8,1 \\
\hline$S R+A C T$ & 1018,8 bc & $13,48 \mathrm{ab}$ & 40,0 & 5,3 & 6,1 \\
\hline $\mathrm{SR}_{\dot{r}} \mathrm{AP}$ & $865,0 \quad c$ & $13,42 \mathrm{ab}$ & 38,7 & 5,3 & 7,9 \\
\hline $\mathrm{SP}+\mathrm{ACT}$ & $1266,4 \mathrm{~b}$ & $14,00 \mathrm{ab}$ & 43,0 & 6,0 & 8,2 \\
\hline $\mathrm{SP}+\mathrm{AP}$ & $1198,8 \mathrm{bc}$ & $14,26 \mathrm{ab}$ & 41,0 & 6,0 & 7,3 \\
\hline $\mathrm{SD}+\mathrm{ACT}$ & $1875,6 \mathrm{a}$ & $12,06 \quad b$ & 44,3 & 9,7 & 21,4 \\
\hline $\mathrm{SD}+\mathrm{AP}$ & 1908,8 a & $13,02 a b$ & 43,7 & 8,3 & 23,1 \\
\hline DMS & 384,1797 & 2,5571 & & & \\
\hline C.V. res. a (\%) & 42,2258 & 8,7327 & & & \\
\hline C.V. res. b(\%) & ) 23,9933 & 7,0373 & & & \\
\hline
\end{tabular}

* médias seguidas por uma mesma letra, na coluna, não diferem estatistica mente entre si pelo teste de Tukey a 5\% de probabilidade.

** Valores médios de 2 repetições. 
Tabela 8 - Efeitos de sistemas de preparo do solo e modos de adubação em algumas características agronōmicas da soja, no ano agrícola 1982/83.

\begin{tabular}{|c|c|c|c|c|c|}
\hline Tratamento & $\begin{array}{c}\text { Rendimento } \\
\text { grãos* } \\
\text { (kg/ha) }\end{array}$ & $\begin{array}{c}\text { Peso de } 100 \\
\text { grãos* } \\
(g)\end{array}$ & $\begin{array}{l}\text { Altura } \\
\text { de } \\
\text { planta** } \\
\text { (cIn) }\end{array}$ & $\begin{array}{l}\text { Inserção } \\
\text { da } 1 a ̣ \\
\text { vagem** } \\
\text { (cm) }\end{array}$ & $\begin{array}{l}\text { "stand"** } \\
\text { (no plan- } \\
\text { tas } / \mathrm{m} \text { ) }\end{array}$ \\
\hline $\mathrm{SC}+\mathrm{ACT}$ & $1772,0 \mathrm{ab}$ & $22,28 \quad a$ & $60,72 \mathrm{bc}$ & $5,22 b$ & $10,50 \mathrm{~b}$ \\
\hline $\mathrm{SC}+\mathrm{AP}$ & $1542,0 \mathrm{abc}$ & $22,24 a$ & $57,64 \mathrm{bcd}$ & $5,04 \mathrm{~b}$ & $10,14 \mathrm{bc}$ \\
\hline $\mathrm{SR}+\mathrm{ACT}$ & $972,8 \mathrm{c}$ & $22,96 \mathrm{a}$ & $57,34 \mathrm{bcd}$ & $4,82 \mathrm{~b}$ & $7,16 \mathrm{~d}$ \\
\hline $\mathrm{SR}+\mathrm{AP}$ & $1048,4 \mathrm{C}$ & $22,54 a$ & $50,54 d$ & $4,02 \mathrm{~b}$ & $7,74 \mathrm{~cd}$ \\
\hline $\mathrm{SP}+\mathrm{ACT}$ & $1090,8 \mathrm{bc}$ & $22,22 \mathrm{a}$ & $55,02 \mathrm{~cd}$ & $4,32 \mathrm{~b}$ & $8,38 \mathrm{bcd}$ \\
\hline $\mathrm{SP}+\mathrm{AP}$ & $1136,6 \mathrm{bc}$ & $22,06 a$ & $53,96 \mathrm{~cd}$ & $4,22 \mathrm{~b}$ & $8,28 \mathrm{bcd}$ \\
\hline $\mathrm{SD}+\mathrm{ACT}$ & $2116,2 a$ & $19,64 \mathrm{~b}$ & $70,82 a$ & $10,14 a$ & $23,94 a$ \\
\hline $\mathrm{SD}+\mathrm{AP}$ & $1930,6 \mathrm{a}$ & $18,74 \mathrm{~b}$ & $65,84 \mathrm{ab}$ & $11,16 \mathrm{a}$ & $23,66 \mathrm{a}$ \\
\hline DMS & 682,1721 & 2,1089 & 9,8418 & 2,2504 & 2,6404 \\
\hline C.V. res.a $(\%)$ & 31,1027 & 4,0478 & 10,1573 & 18,5309 & 15,2136 \\
\hline C.V. res.b (\%) & - 32,2632 & 4,8234 & 7,8175 & 10,2622 & 16,3772 \\
\hline
\end{tabular}

* Médias seguidas por uma mesma letra, na coluna, não diferem estatisticamente entre si pelo teste de Tukey a 5.\% de probabilidade. 
Tabela 9 - Comparação de médias de "stand" da soja (no de plantas/m) nos diversos sistemas de preparo de solo dentro dos diferentes mo dos de adubação, pelo teste de Tukey a 5\% de probabilidade no ano agrícola 1982/83.

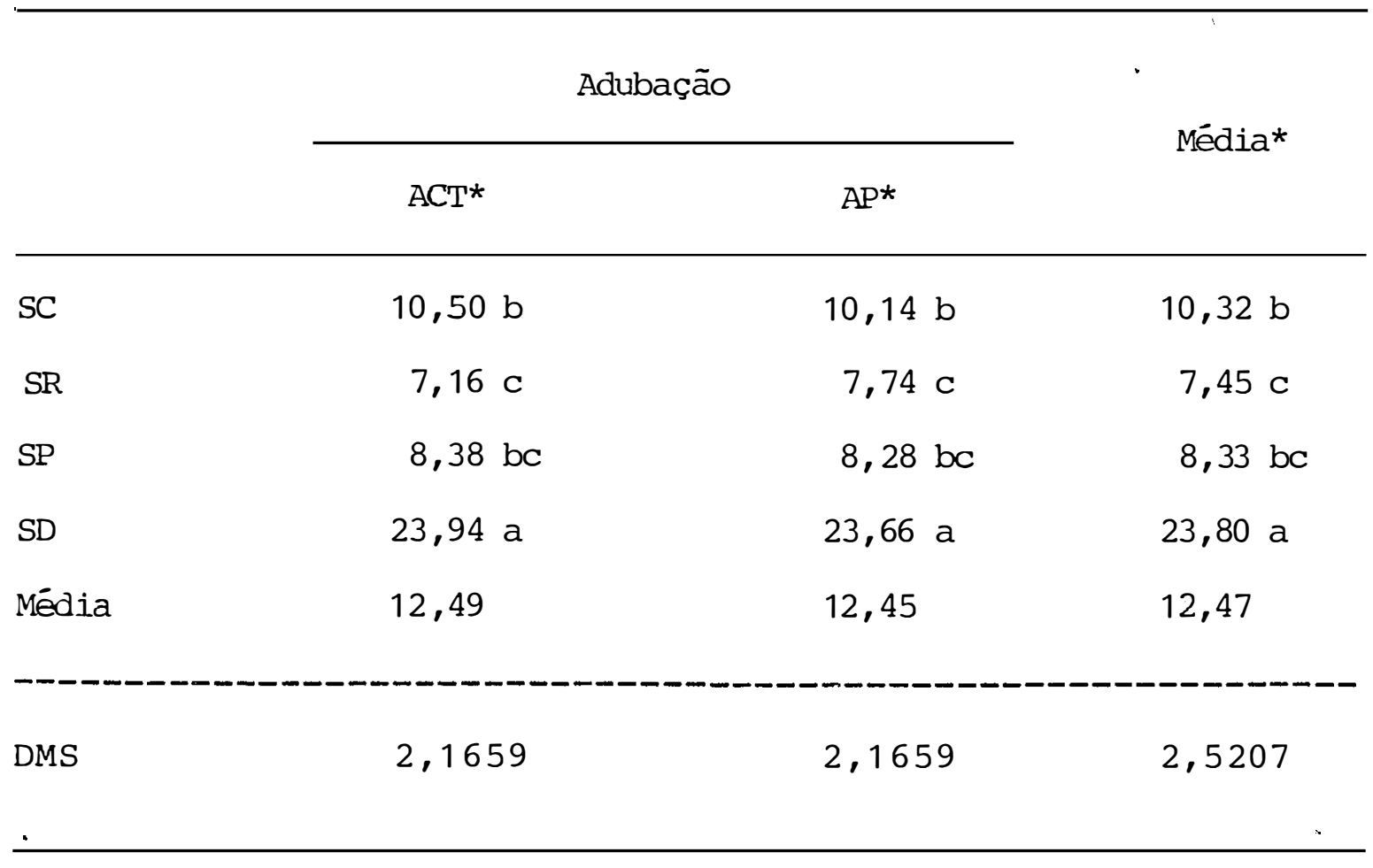

* Médias seguidas por uma mesma letra, na coluna, não diferem estatisticamente entre si. 
Tabela 10 - Comparação de média de altura da planta de soja (cm) nos diversos sistemas de preparo de solo dentro dos diferentes modos de adubação, pelo teste de Tukey a 5\% de probabilidade , no ano agrícola 1982/83.

\begin{tabular}{|c|c|c|c|}
\hline \multirow{2}{*}{$\begin{array}{l}\text { Preparo } \\
\text { do solo }\end{array}$} & \multicolumn{2}{|c|}{ Ađubação } & \multirow{2}{*}{ Média* } \\
\hline & ACT* & $\mathrm{AP}$ * & \\
\hline SC & $60,72 \mathrm{~b}$ & $57,64 \mathrm{~b}$ & $59,18 \mathrm{~b}$ \\
\hline SR & $57,34 \mathrm{~b}$ & $50,54 \mathrm{~b}$ & $53,94 \mathrm{~b}$ \\
\hline SP & $55,02 \mathrm{~b}$ & $53,96 \mathrm{~b}$ & $54,49 \mathrm{~b}$ \\
\hline SD & $70,82 \mathrm{a}$ & $65,84 a$ & $68,33 \mathrm{a}$ \\
\hline média & 60,97 & 56,99 & 58,98 \\
\hline DMS & 8,0734 & 8,0734 & 7,9574 \\
\hline
\end{tabular}

* Médias seguidas por uma mesma letra, na coluna, não diferem estatisticamente entre si. 
Tabela 11 - Comparação de médias de altura de inserção da 1ạ vagem de so ja $(\mathrm{cm})$ nos diversos sistemas de preparo de solo dentro dos diferentes modos de adubação, pelo teste de Tukey a 5\% de pro babilidade no ano agrícola 1982/83.

\begin{tabular}{|c|c|c|c|}
\hline \multirow{2}{*}{$\begin{array}{l}\text { Preparo do } \\
\text { solo }\end{array}$} & \multicolumn{2}{|c|}{ Adubação } & \multirow{2}{*}{ Média* } \\
\hline & ACT* & $\mathrm{AP} *$ & \\
\hline SC & $5,22 \mathrm{~b}$ & $5,04 \mathrm{~b}$ & $5,13 \mathrm{~b}$ \\
\hline$S R$ & $4,82 \mathrm{~b}$ & $4,02 \mathrm{~b}$ & $4,42 \mathrm{~b}$ \\
\hline SP & $4,32 \mathrm{~b}$ & $4,22 \mathrm{~b}$ & $4,27 \mathrm{~b}$ \\
\hline SD & $10,14 a$ & $11,16 \mathrm{a}$ & $10,65 \mathrm{a}$ \\
\hline média & 6,12 & 6,11 & 6,12 \\
\hline DMS & 1,8460 & 1,8460 & 1,5056 \\
\hline
\end{tabular}

* Médias seguidas por uma mesma letra, na coluna, não diferem estatisticamente entre si. 
Tabela 12 - Comparação de médias de altura da planta de soja (cm) dos di ferentes modos de adubação dentro do sistema de preparc reduzido do solo pelo teste de Tukey a 5\% de probabilidade no a no agrícola 1982/83.

\begin{tabular}{lrc}
\hline \multirow{2}{*}{$\begin{array}{l}\text { Preparo do } \\
\text { solo }\end{array}$} & \multicolumn{2}{c}{ Adubação } \\
\cline { 2 - 3 } & \multicolumn{1}{c}{ ACT* } & AP* \\
\hline SR & 57,34 a & $50,54 \mathrm{~b}$ \\
DMS & 5,9205 & \\
\hline
\end{tabular}

* Médias seguidas por uma mesma letra, na linha, não diferem estatistica mente entre si. 
Tabela 13 - Comparação de médias de rendimentos de grãos de soja (kg/ha) nos diversos sistemas de preparo de solo dentro dos diferentes modos de ajubaçãor, pelo teste de Tukey a 5\% de probabili dade nos anos agrícolas de 1981/82 e 1982/83.

\begin{tabular}{|c|c|c|c|}
\hline \multirow{2}{*}{$\begin{array}{l}\text { Preparo } \\
\text { do solo }\end{array}$} & \multicolumn{2}{|c|}{ Adubação } & \multirow{2}{*}{ Média* } \\
\hline & $\mathrm{ACT}^{*}$ & $A P^{*}$ & \\
\hline & \multicolumn{3}{|c|}{ Ano agrícola 1981/82 } \\
\hline SC & $1200,2 \mathrm{~b}$ & $1220,4 \mathrm{~b}$ & $1210,3 \mathrm{ab}$ \\
\hline $\mathrm{SR}$ & $1018,8 \mathrm{~b}$ & $865,0 \mathrm{c}$ & $941,9 \mathrm{~b}$ \\
\hline $\mathrm{SP}$ & $1266,4 \mathrm{~b}$ & $1198,8 \mathrm{~b}$ & $1232,6 \mathrm{ab}$ \\
\hline SD & $1875,6 a$ & $1908,8 \mathrm{a}$ & $1892,2 \mathrm{a}$ \\
\hline Média & 1340,25 & 1298,25 & 1319,25 \\
\hline \multirow[t]{2}{*}{ DMS } & 315,1474 & 315,1474 & 739,8689 \\
\hline & \multicolumn{3}{|c|}{ Ano agrícola 1982/83 } \\
\hline SC & $1772,0 \mathrm{a}$ & $1542,0 \mathrm{ab}$ & $1657,0 \mathrm{ab}$ \\
\hline $\mathrm{SR}$ & $972,8 \mathrm{~b}$ & $1048,4 \mathrm{~b}$ & $1010,6 \mathrm{c}$ \\
\hline SP. & $1090,8 \mathrm{~b}$ & $1136,6 \mathrm{~b}$ & $1113,7 \mathrm{bc}$ \\
\hline $\mathrm{SD}$ & 2116,2 a & 1930,6 a & $2023,4 a$ \\
\hline Média & 1487,95 & 1414,4 & 1451,17 \\
\hline DMS & 559,5943 & 559,5943 & 599,4699 \\
\hline
\end{tabular}

* Médias seguidas por uma mesma letra,: na coluna, não diferem estatisticamente entre si. 
Tabela 14 - Comparação de médias de peso de 100 grãos de soja (g) nos di versos sistemas de preparo do solo dentro dos diferentes modos de adubação, pelo teste de Tukey a 5\% de probabilidade , nos anos agrícolas 1981/82 e 1982/83.

\begin{tabular}{|c|c|c|c|}
\hline \multirow{2}{*}{$\begin{array}{l}\text { Preparo } \\
\text { do solo }\end{array}$} & \multicolumn{2}{|c|}{ Ađubação } & \multirow{2}{*}{ Média* } \\
\hline & $\mathrm{ACT}^{*}$ & $\mathrm{AP} *$ & \\
\hline \multicolumn{4}{|c|}{ Ano agrícola 1981/82 } \\
\hline SC & 15,06 a & $13,70 \mathrm{a}$ & $14,38 \mathrm{a}$ \\
\hline SR & $13,48 \mathrm{ab}$ & 13,42 a & $13,45 \mathrm{ab}$ \\
\hline SP & $14,00 \mathrm{ab}$ & $14,26 \mathrm{a}$ & $14,13 \mathrm{a}$ \\
\hline SD & $12,06 \mathrm{~b}$ & 13,02 a & $12,54 \mathrm{~b}$ \\
\hline Média & 13,65 & 13,60 & 13,62 \\
\hline DMS & 2,0976 & 2,0976 & 1,5802 \\
\hline \multicolumn{4}{|c|}{ Ano agrícola 1982/83 } \\
\hline SC & 22,28 a & 22,24 a & 22,26 a \\
\hline SR & 22,96 a & 22,54 a & 22,75 a \\
\hline SP & $22,22 \mathrm{a}$ & 22,06 a & 22,14 a \\
\hline SD & $19,64 \mathrm{~b}$ & $18,74 \mathrm{~b}$ & $19,19 \mathrm{~b}$ \\
\hline Média & 21,77 & 21,39 & 21,58 \\
\hline DMS & 1,7300 & 1,7300 & 1,1604 \\
\hline
\end{tabular}

* Médias seguidas por uma mesma letra, na coluna, não diferem estatisticamente entre si. 
Tabela 15 - Efeito do preparo do solo e modo de aplicação de fertilizantes na distribuição do sistema radicular da soja, expresso em gramas de peso seco/planta, no ano agrícola 1982/83.

\begin{tabular}{|c|c|c|c|c|c|}
\hline \multirow{2}{*}{ Tratamento } & \multicolumn{5}{|c|}{ Profundidade $(\mathrm{cm})$} \\
\hline & $0-5$ & $5-10$ & $10-15$ & $15-20$ & $0-20$ \\
\hline $\mathrm{SC}+\mathrm{ACT}$ & 0,766 & 0,468 & 0,064 & 0,019 & 1,317 \\
\hline $\mathrm{SC}+\mathrm{AP}$ & 1,035 & 0,735 & 0,177 & 0,035 & 1,922 \\
\hline $\mathrm{SR}+\mathrm{ACT}$ & 0,908 & 0,886 & 0,090 & 0,030 & 1,914 \\
\hline $\mathrm{SR}+\mathrm{AP}$ & $0,7.95$ & 0,782 & 0,066 & 0,034 & 1,677 \\
\hline $\mathrm{SP}+\mathrm{ACP}$ & 0,887 & 0,470 & 0,062 & 0,016 & 1,435 \\
\hline $\mathrm{SP}+\mathrm{AP}$ & 1,232 & 0,657 & 0,085 & 0,038 & 2,012 \\
\hline $\mathrm{SD}+\mathrm{ACT}$ & 0,531 & 0,188 & 0,035 & 0,012 & $0,7.66$ \\
\hline $\mathrm{SD}+\mathrm{AP}$ & 0,680 & 0,312 & 0,030 & 0,020 & 1,042 \\
\hline
\end{tabular}


Tabela 16 - Efeito do preparo do solo e modo de aplicação de fertilizantes na distribuição do sistema radicular da soja, expresso em porcentagem de peso seco/planta, no ano agrícola 1982/83.

\section{Profundidade (cm)}

\begin{tabular}{|c|c|c|c|c|c|}
\hline \multirow{2}{*}{ 'Tratamento } & \\
\hline & $0-5$ & $5-10$ & $10-15$ & $15-20$ & $0-20$ \\
\hline $\mathrm{SC}+\mathrm{ACT}$ & 58,18 & 35,54 & 4,86 & 1,44 & 100,00 \\
\hline $\mathrm{SC}+\mathrm{AP}$ & 53,85 & 38,24 & 6,09 & 1,82 & 100,00 \\
\hline$S R+A C T$ & 47,44 & 46,29 & 4,70 & 1,57 & 100,00 \\
\hline$S R+A P$ & 47,41 & 46,63 & 3,94 & 2,02 & 100,00 \\
\hline $\mathrm{SP}+\mathrm{ACT}$ & 61,81 & 32,75 & 4,32 & 1,12 & 100,00 \\
\hline $\mathrm{SP}+\mathrm{AP}$ & 61,24 & 32,65 & 4,22 & 1,89 & 100,00 \\
\hline $\mathrm{SD}+\mathrm{ACT}$ & 69,32 & 24,54 & 4,57 & 1,57 & 100,00 \\
\hline $\mathrm{SD}+\mathrm{AP}$ & 65,26 & 29,94 & 2,88 & 1,92 & 100,00 \\
\hline
\end{tabular}


.80 .

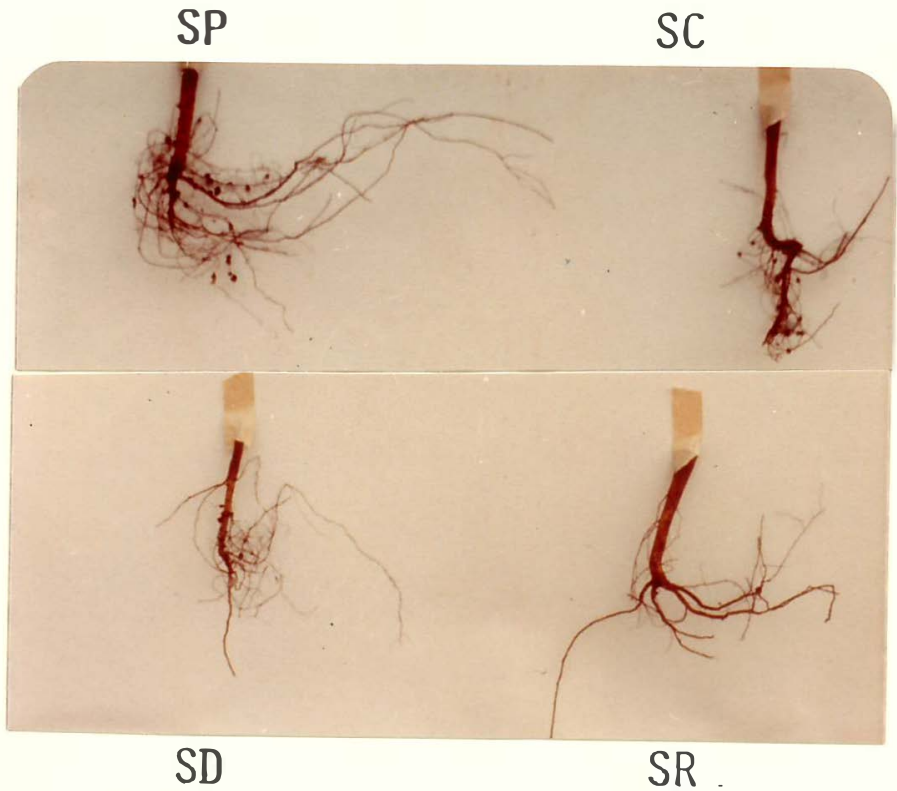

Figura 17 - Efeito dos sistemas de preparo do solo no desenvolvimento radicular da soja, no ano agricola $1982 / 83$. 


\subsection{Viabilidade econōmica}

Observa-se pelos dados da Tabela 17 que o custo operacional total é semelhante para todos os sistemas de prepa ro do solo empregados no 19 ano agrícola (1981/82).

Porém no 2: ano de cultivo (Tabela 18) o sistema de semeadura direta apresenta valores ligeiramente superiores de custo operacional total.

o fator que mais contribuiu para a elevação deste custo foi o emprego de herbicidas, sendo que nem mesmo a redução nos custos de combustíveis apresentada pelo sistema, foi suficiente para neutralizar os gastós referentés ao controle de ervas daninhas, discordando em parte dos resultados obti dos por LAURENTI e FUENTES (1981).

A exemplo do que obteve RAMOS (1981), o sistema de preparo reduzido foi aquele que apresentou os menores custos totais.

Nos dois anos agrícolas estudados, o sistema de semeadura direta mostrou ser o mais eficiente entre os métodos de preparo de solo empregados, apresentando uma taxa residual média positiva. Cabe ressaltar que os sistemas de super preparo e preparo reduzido apresentaram taxa residual negativa, sendo portanto, inviāveis economicamente.

Considerando que o sistema de semeadura direta, além de apresentar melhores taxas residuais, fornece outras vantagens, não computadas na anālise econômica do presente tra 
balho, como menores perdas por erosão, semeadura na época apro priada por dispensar o tempo gasto com o preparo prévio do ter reno e economia de tempo, pode-se concluir por esses dados que existe maior viabilidade econômica nesse sistema. 


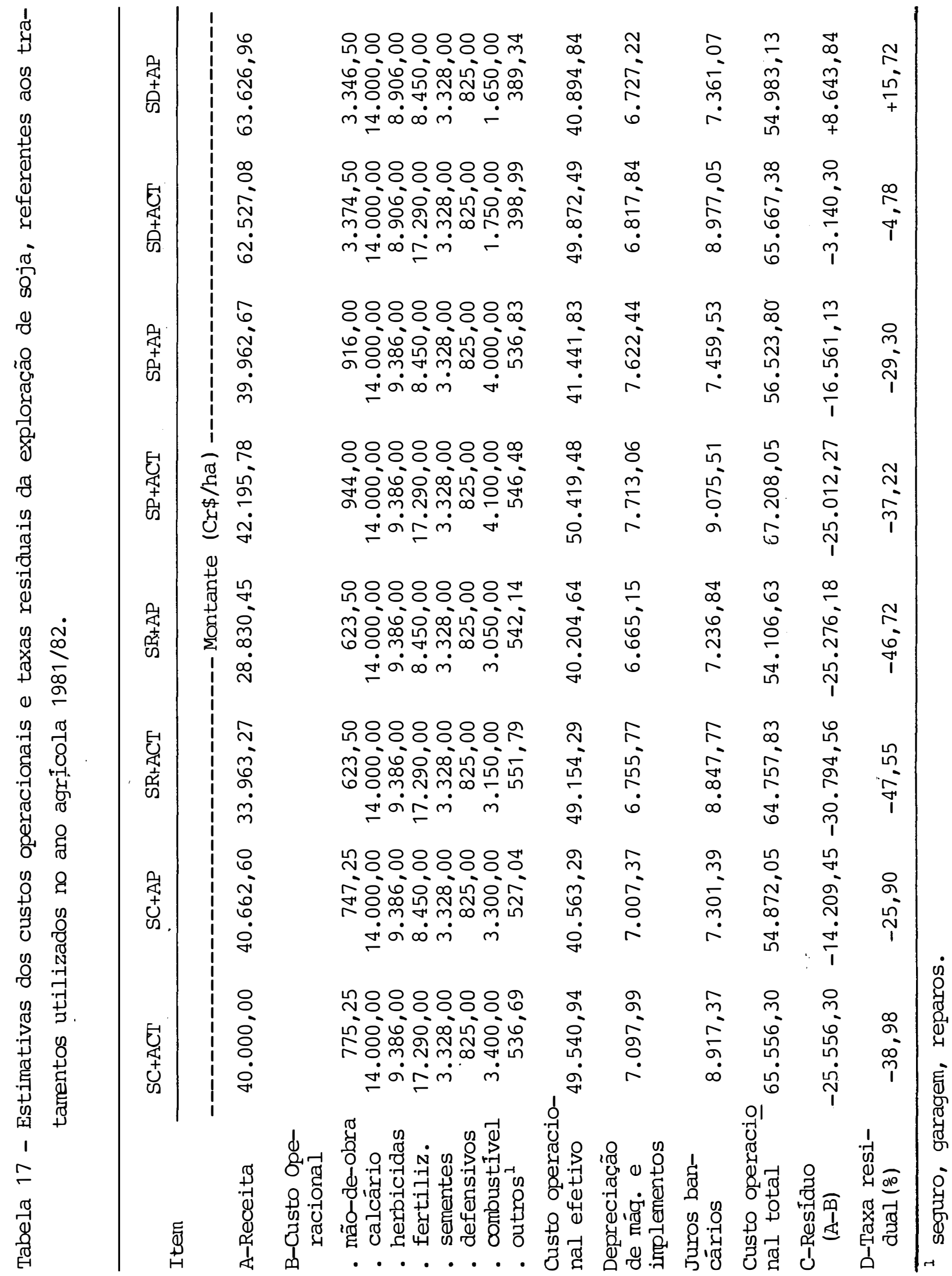




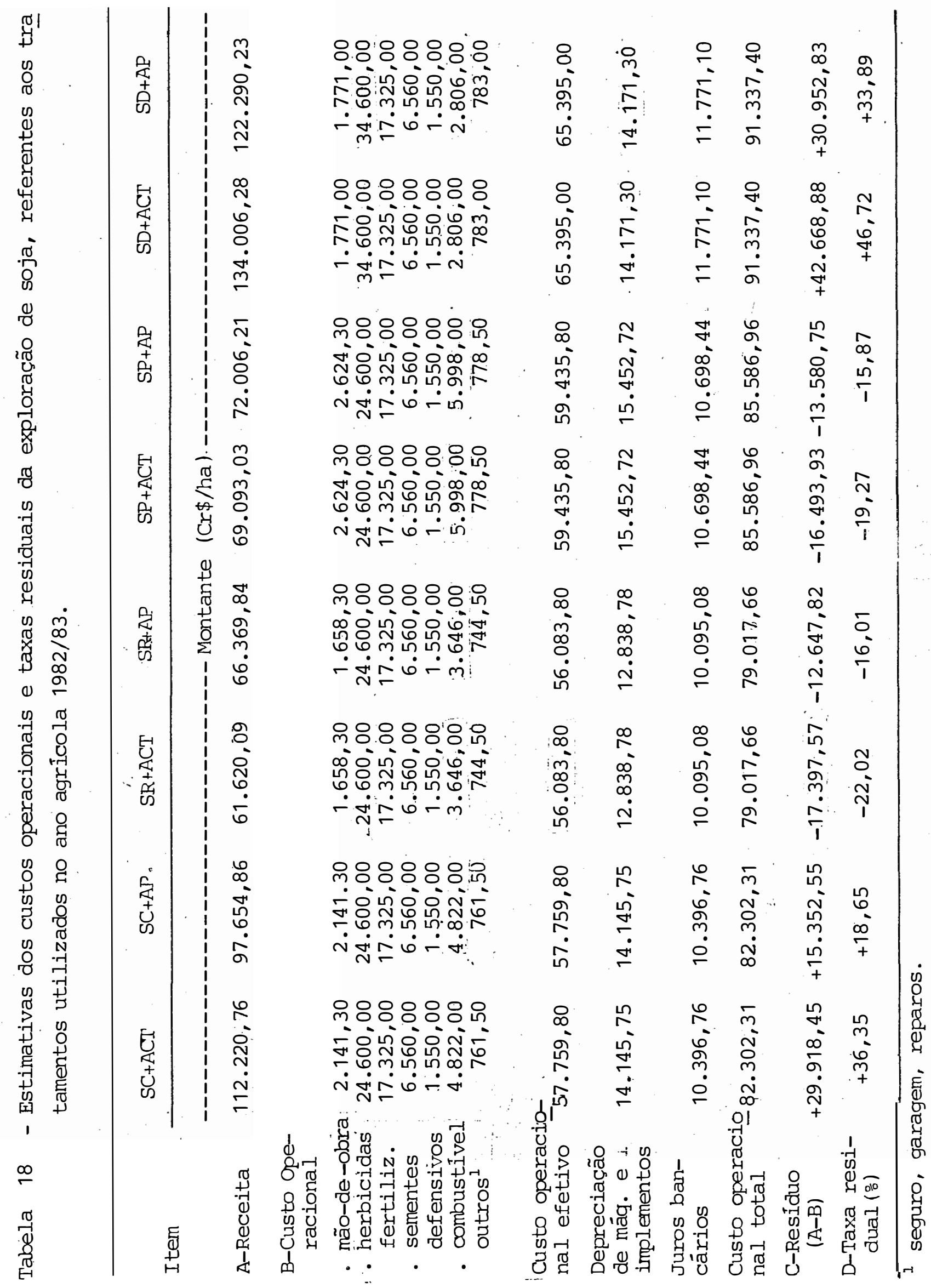




\section{CONCLUSÕES}

Do presente trabalho podem ser tiradas as seguintes conclusões:

1. O sistema de semeadura direta apresentou melhor "stand", o

- que resultou em maior rendimento de grãos, sendo também o mais viável economicamente.

2. O modo de aplicação de adubos (correção ou parcelado) não influenciou significativamente no rendimento de griàos de so ja nos diferentes sistemas de preparo.

3. A maior concentração de nutrientes na camada mais superficial do solo $(0$ a $10 \mathrm{~cm}$ ), encontrada nos sistemas reduzido e de semeadura direta, assim como a distribuição mais uniforme dos nutrientes na camada de 0 a $20 \mathrm{~cm}$, nos sistemas con- 
vencional e de superpreparo, não afetaram no rendimento de grãos da soja.

4. Os sistemas de preparo e adubação não influenciaram de forma marcante a absorção de nutrientes pelas plantas, visto que nas análises do tecido foliar os teores de nutrientes estavam próximos ao ideal em todos os tratamentos.

5. Os sistemas de preparoreaduzido, preparo convencional e super preparo induziram a formação de camadas de compactação a dị ferentes profundidades, ou seja, 10,20 e $20 \mathrm{~cm}$, respectiva mente.

6. Tais camadas foram as responsáveis pela menor taxa de infil tração de água no solo apresentada pelos sistemas convencio nal, reduzido e de superpreparo. O sistema de semeadura direta aumentou a taxa de infiltração de água no solo.

7. O sistema de semeadura direta propiciou ao solo maior homogeneidade estrutural, redundando no melhor aproveitamento da āgua disponível no solo pela planta:

8. Tanto as alturas de planta como a da inserção da 1ạ vagem, foram superiores no sistema de semeadura direta, sendo que a última atingiu os valores mais próximos do ideal no refe- 
rido sistema, resultando portanto em menor perda de grãos durante a colheita.

9. O custo operacional total é semelhante para todos os sistemas de preparo de solo estudados. 


\section{LITERATURA CITADA}

ALLMARAS, R.R.; R.E. BURWELL e R.L. HOLT, 1967. Plow-layer porosity and surface roughness from tillage as affected by initial porosity and soil moisture at tillage time. Soil Sci. Soc. Amer. Proc., 31(4): 550-556.

BARNI, N.A. e H. BERGAMASCHI, 1981. Técnicas culturais. 2. Alguns princípios técnicos para a semeadura. In: MIYASAKA, $S$. e J.C. MEDINA, eds. A soja no Brasil. p.476-480.

BARNI, N.A.; J.E.S. GOMES E J.C. GONÇALVES, 1982. Influência do tamanho de semente, profundidade e densidade de semeadura sobre o rendimento de grãos de soja. In: II Seminário Nacional de Pesquisa de Soja, Anais. EMBRAPA, CNPSO, Brasilia, p.207-225. 
BATAGLIA, O.C. e H.A.A. MASCARENHAS, 1977. Absorção de nutrientes pela soja. Campinas, Inst. Agron., 36p. [Boletim Técnico, 41] .

BAUMER, K. e W.A.P. BAKERMANS, 1973. Zero-tillage. Adv. in Agron. New York, 25: 77-125.

BAVER, L.D.; W.H. GARDNER; W.R. GARDNER, 1973. Física de suelos. México, Ed. Hispano-Americana. 529p.

BENEZ, S.H.; C.A. GAMERO e C. PIEDADE Jr., 1979. Influência do preparo do solo no desenvolvimento do sistema radicular dá: soja [Glycine $\max$ (L.) Merril]. Anais do IX Congresso Nacional de Engenharia Agrícola. Campina Grande, PB, p.334-341.

BERTRAND, A.R., 1965. Rate of water intake in the field. In: BLACK, C.A., ed. Methods of soil analysis. Madison. Amer. Soc. Agron., 1: 197-209.

BEZERRA, J.E.S., 1978. Influềicia de sistemas de manejo do solo sobre algumas propriedades físicas e químicas de um Podzólico Vermelho Amarelo Câmbico Distrófico, fase terraço, e sobre a produção de milho (Zea mays L.). Viçosa, UFV, 61p. [Dissertação de Mestrado] . 
BLAKE, G.R., 1965. Bulk density. In: BLACK, C.A., ed. Methods of soil analysis. Madison. Amer. Soc. Agron., 1: 374-390.

BLEVINS, R.L.; L.W. MURDOCK e G.W. THOMAS, 1978. Effect of lime application on no-tillage and conventionally tilled corn. Agronomy Journal. Madison, 70: 322-326.

BLEVINS, R.L.; G.W. THOMAS e P.L. CORNELIUS, 1977. Influence of no-tillage and nitrogen fertilization on certain soil properties after 5 years of continuous corn. Agron. J., 69: $383-386$.

CAMARGO, O.A., 1983. Compactação do solo e desenvolvimento das. plantas. Campinas, Fundação Cargill, 44 p.

CANNELL, R.Q., 1981. Soil cultural practices reláted to root . development. In: RUSSEL, R.S.; K. IGUE e Y.R. MEHTA. The soil root system in relation to Brasilian Agriculture. Londrina, IAPAR, p.61-80.

CENTURION, J.F., 1982. Balanço hîdrico da região de Ilha Solteira. Científica. São Paulo, $10(1):$ 57-61.

CENTURION, J.F.; F.M. FERNANDES e V.M. NASCIMENTO, 1982. Efeito de sistemas de preparo do solo na cultura da soja em sucessão com trigo e sorgo. In: II Seminário Nacional de Pesquisa de Soja, Anais. EMBRAPA, CNPSo, Brasilia, p.162-166. 
CHAVES, R.S., 1977. Sistemas de preparo de solo para milho (Zea mays L.) em um Podzólico Vermelho Amarelo Câmbico Distrófico fase terraço, da zona da mata de Minas Gerais. Viçosa, UFV, 31p. [Dissertação de Mestrado].

COMISSÃO DE SOLOS, 1960. Levantamento de reconhecimento dos. solos do Estado de São Paulo. Ministério da Agricultura. C.N.E.P.A., 634p. [Boletim no 12].

CORSINI, P.C., 1974. Modificações de características físico-hîdricas em perfis das séries Jaboticabal e Santa Tereza ocasionadas pelo cultivo intenso. Cientifica, $\underline{2}(2): 148$ -161 .

COX, F.R. e E.J. KAMPRATH, 1973. Micronutrient soil tests. In: MORTVEDT, J.J.; P.M. GIORDANO e W.L. LINDSAY. Micronutrients in Agriculture. Madison, Soil Science Society of America, p. 280-317.

DAY, P.R., 1965. Particle fractionation and particle-size analysis. In: BLACK, C.A., ed. Methods of soil analysis. Madison. Amer. Soc. Agron., 1: 545-567.

DEMATTÊ, J.L.I., 1980. Levantamento detalhado dos solos do "Campus" Experimental de Ilha Solteira. .Piracicaba, SP, 131p. [Mimeografado] . 
EMPRESA BRASILEIRA DE PESQUiSA AgROPECUÁRIA. Centro de Pesquisa Agropecuária dos Cerrados, 1976. Relatório Técnico Anual. Brasilia, 150p.

EMPRESA BRASILEIRA DE PESQUISA AGROPECUÂRIA. Centro de Pesquisa Agropecuária dos Cerrados, 1980. Relatório Técnic̉o Anual. Brasilia, 170p.

FINK, R.J. e D. WESLEY, 1974. Corn yield as affected by fertilization and tillage system. Agronomy Journal. Madison, $\underline{66}(1): 70-71$.

FORSYTHE, W.M., 1967. Las propriedades físicas, los factores físicos de crescimiento y la productividade del suelo. Fitotecnia Latinoamericana. Costa Rica, $\underline{4}(2):$ 165-176.

GAMERO, C.A.; S.H. BENEZ e P.C. MATTOS, 1979. Influência do preparo do solo na produção de soja [Glycine max (L.) Merril]. Anais do IX Congresso Nacional de Engenharia Agrícola. Campina Grande, PB, p.328-333.

GARGANTINI, H.; F.A.S. COELHO; F. VERLENGIA e E. SOARES, 1972. Levantamento de fertilidade dos solos do Estado de São Paulo - 1ạ aproximação. In: COELHO, F.A.S. e F. VERLENGIA. Fertilidade do solo. Campinas, Instituto Campineiro de Ensino Agricola, p.356-384. 
GLÓRIA, N.A.; R.A. CATANI e T. MATUO, 1965. A determinação da capacidade de troca de cátions do solo pelo método do EDTA.

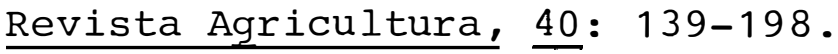

GRIFFITH, D.R.; J.V. MANNERING e W.C. MOLDENHAUER, 1977. Conservation tillage in the Eastern Corn Belt. J. Soil and water conservation, $32(1): 20-28$.

GUEDES, L.V.M.; T.L. WILES e R.A. VEDOATO, 1979. Ensaio de longo prazo com comparações entre plantio direto, preparo mínimo e plantio convencional. In: I Seminärio Nacional de Pesquisa de Soja, Anais, CNPSo. Londrina, PR, p.59-65.

HEWITT, J.S. e A.R. DEXTER, 1980. Effects of tillage and stubble management on the structure of a swelling soil. Soil Sci. J. $\underline{31}(2): 203-215$.

HILLEL, D. , 1970. Solo e áqua; fenōmenos e princípios físicos. Porto Alegre. UFRGS, $231 \mathrm{p}$.

KAWASAKI, H.; F. IWATA e M.V. MESQUITA FILHO, 1980. Estudo do desenvolvimento do sistema radicular da soja no cerrado. In: Relatório parcial do projeto da cooperação em pesquisa agrícola nos cerrados do Brasil, 1978-1980. EMBRAPA/CPAC/ JICA, Brasilia, p.158-173. 
KINCADE, R.T., 1972. The role of Paraquat in soybean stubble plant systems in the Mississipi Delta. In: No-tillage Systems Symposium. Ohio State Univ., Columbus, p.113-123.

LAL, R., 1975. No-tillage effects on soil conditions and crop response on an Alfissol in Southern Nigeria. Amer. Soc. Agron. Abstr., 38p.

LAL, R., 1976. No-tillage effects on soil properties under different crops in Western Nigeria. Soil Sci. Soc. Am. J., 40: $762-768$.

LARSON, W.E., 1964. Soil parameters for evaluating tillage needs and operations. Soil Sci. Soc. Amer. Proc., 28(1): 118-122.

LAURENTI, A.C. e L.R. FUENTES, 1981. Avaliação de custos, rentabilidade e risco. In: Plantio direto no estado do Paraná. Londrina. IAPAR, p.215-237. [Circular no 23].

LEWIS, W.M., 1972. No-tillage production systems for double cropping and for cotton and other crops. In: No-tillage Systems Symposium. Ohio State Univ., Columbus, p.146-152.

LOPES, A.S., 1983. Solos sob "cerrado": caracteristicas, pro-. priedades e manejo. Instituto da Potassa e Fosfato: Instituto Internacional da Potassa, ed. Piracicaba, 162p. 
MACHADO, J.A. e A.C.R. BRUM, 1978. Efeitos de sistemas de cultivos em algumas propriedades físicas do solo. Rev. Bras. de Ciência do Solo, 2 (2): 81-83.

MALAVOLTA, E.; H.P. HAAG; F.A.F. MELLO e M.O.C. BRASIL SOBRO, 1974. Nutrição mineral e adubação de plantas cultivadas. São Paulo, Livraria Pioneira Editora. 727p.

MAtSUnAGA, M.; P.F. BELMENANS; P.E.N. TOLEDO; R.D. DULLEY; H. OKAWA e I.A. PEDROSO, 1976. Metodologia de custo de produção utilizada pela I.E.A. Agricultura em São Paulo, ano XXIII, Tomo I, p.123-140.

MCMAHON, M.A. e G.W. THOMAS, 1976. Anion leaching in two Kentucky soils under conventional tillage and killed sod mulch. Agronomy J., 68: 437-442.

MOURA, A.R.B., 1981. Efeito de sistemas de manejo na cultura do milho (Zea mays L.) e sobre algumas propriedades fisicas D. e químicas de um Podzólico Vermelho Amarelo Câmbico Distrófico fase terraço. Viçosa, UFV, 125p. [Dissertação de Mestrado]

MUZILLI, O., 1983. Influência do sistema de plantio direto, comparado ao convencional, sobre a fertilidade da camada arável do solo. Rev. Bras. Ci. Solo. Campinas, $\underline{7}(1):$ 95-102. 
OHMURA, T. e R.W. HOWELL, 1960. Inhibitory effect of water on oxigen consumption by plant materials. Plant Physiol., 35: 184-193.

PEREIRA, J., 1981. Introdução e evolução da soja no Brasil; 11. No cerràdo do Brasil Central. In: MIYASAKA, S. e J.C. MEDINA, eds. A soja no Brasil. p.46-49.

PHILLIPS, J.A., 1970. No-tillage fertilization principles. In: No-tillage research conference, Lexington.

PHILLIPS, R.E. e D. KIRKHAM, 1962. Soil compaction in the field and corn growth. Agronomy Journal. Madison, 54 (7): 29-34.

PHILLIPS, R.E.; R.L. BLEVINS; G.W. THOMAS; W.W. FRYE e J.H. PHILLIPS, 1980. No-tillage Agriculture. Science, 108 (448): 1110.

PIMENTEL GOMES, F., 1977. Curso de Estatistica experimental. 7ed. Piracicatı, Livraria Nobel Editora, 430p.

QUEIROZ, E.F.; N. NEUMAIER e E. TORRES, 1979. Ecologia e manejo da cultura. In: Ecologia, manejo e adubação da soja. EMBRAPA/ CNPSo. Londrina, PR, p.63-91. [Circular técnica nọ 2]. 
QUEIROZ, E.F.; N. NEUMAIER; E. TORRES; L.A.G. PEREIRA; A. BIANCHETTI; F. TERAZAWA; J.B. PALHANO e J. YAMASHITA, 1981. Recomendações técnicas para a cultura mecānica. In: MIYASAKA, S. e J.C. MEDINA, eds. A soja no Brasil, p.701-710.

RAIJ, B.V., 1981. Avaliação da fertilidade do solo. Instituto da Potassa e Fosfato: Instituto Internacional da Potassa, ed. Piracicaba, $142 \mathrm{p}$.

RAIJ, B.V. e M.A.T. ZULLO, 1977. Métodos de análise de solo. Campinas, Inst. Agron. 16p. [Circular 63].

RAMOS, M.G., 1974. Sistemas de preparo minimo do solo: Técnicas. e perspectivas para o Paranā. Estação Experimental de Ponta Grossa, IPEAME, Ponta Grossa, 17p. [Mimeografado] .

RAMOS, M., 1981. Manejo do solo e sistemas de cultivo; 4. Sistemas de preparo mínimo do solo. In: MIYASAKA, S. e J.C. MEDINA, eds. A soja no Brasil, p.369-377.

RAMOS, M. e R. DEDECEK, 1975. Efeitos de sistemas de preparo do solo e modos de aplicação de fertilizantes na produção de soja. Anais do 15 a Congresso Brasileiro de Ciência do Solo. Sociedade Brasileira de Ciência do Solo. Campinas, SP, p. 555-558. 
REEVE, M.J.; P.D. SMITH e A.J. THOMASSON, 1973. The effect of density on water retention properties of field soils. Soil Sci.J., $24(3): 355-367$.

REICHARDT, K., 1975. Processos de transferēncia no sistema so10-planta-atmosferá. 3ed. Piracicaba, CENA, Fundação Cargill, $286 \mathrm{p}$.

RICHARDS, L.A., 1947. Pressure apparatus, construction and use. Agron. Eng., 28: 451-454.

RITCHEY, K.D.; J.E. SILVA; W. ESPINOZA e E. LOBADO, 1981. Downward movement of calcium and the improvement of sobsoil rooting in oxisoils of Brazil. In: RUSSEL, R.S.; K. IGUE e Y.R. MEHTA. The soil/root system in relation to Brazilian Agriculture. Londrina, IAPAR, p.137-151.

ROSELEM, C.A.; J.C.O. SILVÉRIO e J. NAKAGAWA, 1983. Densidade de plantas na cultura da soja. Pesq. agropec. bras. Brasilia, 18(9): $977-984$

SACCHI, E., 1982. Sistemas de preparo do solo: efeito no solo e na produção de milho (Zea mays L.). Piracicaba, ESALQ/ /USP, 97p. [Tese de Doutoramento]. 
SALGADO, J.S., 1979. Efeito de sistemas de aradora e de manejo da palhada do milho em propriedades físicas e quimicas do solo e em características das plantas. Viçosa, UFV, 61p. [Dissertação de Mestrado].

SHEAR, G.M. e W.W. MOSCHLER, 1969. Continuous corn by the notillage and conventional practices. Agronomy Journal. Madison, $61(4): 524-526$.

SHIOYA, T. e S.M. FOLLE, 1980. Avaliação de compactação do solo nos campos dos cerrados. In: Relatório parcial do projeto de cooperação em pesquisa agrícola nos cerrados do Brasil, 1978-1980. EMBRAPA/CPAC/JICA, Brasília, p.187-194.

SIDIRAS, N.; R. DERPSCH e A. MONDARDO, 1983. Influência de diferentes sistemas de preparo do solo na variação da umidade e rendimento da soja, em Latossolo Roxo Distrófico (Oxisol). Rev. bras. Ci. Solo. Campinas, $\underline{7}(1):$ 103-106.

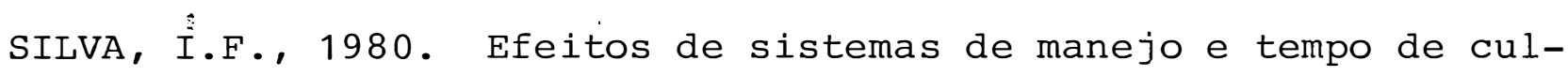
tivo sobre propriedades físicas de um Latossolo. Porto Alegre, UFRGS. 70p. [Dissertação de Mestrado] •

SMALL Jr., H.G. e A.J. OHLROGGE, 1973. Plant analysis as an aid in fertilizing soybeans and peanuts. In: WALSH, L.M. e J.D. BEATON, eds. Soil testing and plant analysis. Madison, Soil Science Society of America, p.315-327. 
TAYLOR, H.H. e E. BURNETT, 1964. Influence of soil strength on the root-growth habits of plants. Soil Science. Baltimore, 98 $(3):$ 1974-1980.

TAYLOR, H.M. e L.F. RATLIFF, 1969. Root elongation rates of cotton and peanuts as a function on soil strength and soil water contend. Soil Sci. Baltimore, 108(2): 113-119.

TOMASINI, R.G.A. e M.A. PERETTI, 1977. Aspectos econômicos na semeadura direta na cultura da soja. Trigo e Soja. Porto Alegre, (19): 16-19.

UEHARA, G. e J. KENG, 1975. Relaciones entre la mineralogía y el manejo de los suelos en la America Latina. In: E. BORNEMISZA e A. ALVARADO (eds.). Manejo de suelos en la America Tropical. Raleigh, NC, USA, p.357-370.

VETTORI, L., 1969. Métodos de análise de solo. Rio de Janeiro. Equipe de pedologia e fertilidade do solo. 24p. [Boletim técnico no 7].

VIEIRA, M.J., 1981. Propriedades físicas do solo. In: Plantio direto no estado do Paraná. Londrina, IAPAR, p.19-32. [Circular no 23]. 
WIETHOLTER, S. , 1975. Comparação de métodos de preparo do solo na sucessão de culturas trigo-soja. Porto Alegre, UFRGS, 91p. [Dissertação de Mestrado] .

WOLF, J.M., 1975. Water constrainsts to corn production in Central Brazil. Department of Agronomy, Cornell University Ithaca, New York, USA, 199p. [Ph.D. Thesis]. 
.102 .

\section{APÊNDICES}


Apêndice 1 - Terweratura $\left({ }^{\circ} \mathrm{C}\right)$ média, umïdade relativa do ar $(\%)$ média e precipi tação, diária para a região de Ilha Solteira - SP.

\begin{tabular}{|c|c|c|c|c|c|c|c|c|c|c|c|c|}
\hline \multirow[b]{2}{*}{ Dias } & \multicolumn{3}{|c|}{ Noventiro/81 } & \multicolumn{3}{|c|}{ Lezeinbro/81 } & \multicolumn{3}{|c|}{ Janeiro/82 } & \multicolumn{3}{|c|}{ Fevereiro/82 } \\
\hline & $\begin{array}{c}\text { Termpera } \\
\text { tura }\end{array}$ & Unidade & $\begin{array}{l}\text { Precipi } \\
\text { taçáo }\end{array}$ & $\begin{array}{c}\text { Tennera } \\
\text { tura }\end{array}$ & Uturudade & $\begin{array}{l}\text { Precipi } \\
\text { tação }\end{array}$ & $\begin{array}{c}\text { Tempera } \\
\text { tura }\end{array}$ & Umidade & $\begin{array}{c}\text { Precipi } \\
\text { taçao }\end{array}$ & $\begin{array}{c}\text { Tenpera } \\
\text { tura }\end{array}$ & Unidade & $\begin{array}{c}\text { Precipip } \\
\text { tacāá }\end{array}$ \\
\hline & 25,2 & 85,0 & 0,0 & 25,8 & 88,2 & 30,7 & 25,7 & & 0,0 & 22,1 & 96,6 & 7,1 \\
\hline 2 & 25,1 & - & 5,2 & 24,5 & 90,9 & 2,5 & 25,4 & & 25,4 & 23,7 & 87,5 & 1,8 \\
\hline 3 & 25,5 & 85,3 & 9,6 & 24,0 & 88,8 & 0,0 & 25,5 & & 0,0 & 23,5 & 87,5 & 10,7 \\
\hline 4 & 24,8 & 90,9 & 12,0 & 25,7 & 87,6 & 0,0 & 25,4 & 89,1 & 0,0 & 23,4 & 85,9 & 22,8 \\
\hline 5 & 27,0 & 88,0 & 0,0 & 27,8 & 85,5 & 0,0 & 26,0 & 85,8 & 0,0 & 23,3 & 90,2 & 29,0 \\
\hline 6 & 27,4 & 81,8 & 28,2 & 26,1 & - & 0,8 & 26,9 & 83,9 & 0,0 & 23,7 & 90,2 & 5,0 \\
\hline 7 & 25,7 & 90,9 & 0,0 & 22,8 & 96,8 & 1,8 & 28,0 & 84,0 & 9,8 & 24,9 & & 0,0 \\
\hline 8 & 27,0 & - & 0,0 & 22,5 & 93,3 & 10,0 & 23,8 & 96,8 & 5,7 & 24,9 & & 0,0 \\
\hline 9 & 26,6 & 88,1 & 25,0 & 22,9 & 96,8 & 0,5 & 24,8 & 89,4 & 0,0 & 25,3 & 96,1 & 0,0 \\
\hline 10 & 25,4 & 92,2 & 0,0 & 24,5 & 93,6 & 0,0 & 24,9 & & 45,6 & 25,7 & 93,2 & 0,0 \\
\hline 11 & 26,4 & 87,9 & 0,0 & 26,6 & 85,6 & 13,9 & 23,8 & 98,4 & 23,8 & 25,5 & 90,4 & 0,0 \\
\hline 12 & 25,1 & 87,4 & 0,0 & 24,8 & 90,7 & 0,0 & 27,0 & 89,5 & 0,0 & 26,7 & 86,4 & 0,0 \\
\hline 13 & 25,1 & 86,5 & 6,0 & 26,7 & - & 0,0 & 27,4 & 91,0 & 0,0 & 26,8 & 89,9 & 0,0 \\
\hline 14 & 25,2 & 90,7 & 0,0 & 26,6 & 86,7 & 0,0 & 28,1 & 86,8 & 0,0 & 27,0 & & 0,0 \\
\hline 15 & 26,4 & 96,8 & , 0,0 & 24,3 & 85,4 & 9,0 & 28,9 & 83,1 & 0,0 & 26,7 & 84,7 & 0,0 \\
\hline 16 & 27,6 & 84,0 & 0,0 & 24,4 & - & 5,0 & 28,8 & 81,6 & 0,0 & 25,7 & 84,0 & 2,8 \\
\hline 17 & 27,9 & 83,0 & 0,0 & 24,5 & 90,9 & 23,4 & 28,0 & & 0,0 & 25,6 & 83,7 & 0,0 \\
\hline 18 & 28,6 & 80,8 & 35,4 & 25,5 & 95,4 & 4,0 & 28,8 & 76,5 & 0,0 & $=26,9$ & 86,2 & 0,0 \\
\hline 19 & 23,3 & 93,8 & 9,6 & 26,1 & 89,6 & 0,0 & 28,0 & 80,9 & 0,0 & 26,8 & 88,7 & 0,0 \\
\hline 20 & 23,5 & 93,8 & 13,2 & 26,7 & - & 58,2 & 24,9 & 83,4 & 0,0 & 27,0 & 83,9 & 0,0 \\
\hline 21 & 24,9 & 92,2 & 0,0 & 13,6 & - & 0,0 & 24,8 & 90,7 & 0,0 & 27,7 & & 0,0 \\
\hline 22 & 27,3 & $93 ; 7$ & 0,0 & 24,7 & 90,9 & 6,3 & 23,8 & 89,2 & 1,8 & 26,0 & 81,1 & 0,0 \\
\hline 23 & 28,3 & 81,7 & 0,0 & 24,3 & 95,3 & 4,5 & 24,6 & 98,4 & 0,0 & 25,5 & 85,7 & 1,5 \\
\hline 24 & 27,9 & 80,2 & 0,0 & 25,6 & 98,4 & 0,0 & 24,0 & & 0,0 & 23,2 & 89,9 & 12,4 \\
\hline 25 & 28,1 & 83,1 & 0,0 & 26,7 & - & 0,0 & 24,1 & 81,9 & 0,0 & 24,4 & 90,8 & 3,4 \\
\hline 26 & 27,8 & 81,4 & 0,0 & 20,9 & - & 0,0 & 24,4 & 86,4 & 0,0 & 25,3 & 91,2 & 0,0 \\
\hline 27 & 28,5 & 79,2 & 0,0 & 24,6 & - & 27,6 & 23,9 & 87,8 & 1,6 & 25,0 & 90,4 & 0,0 \\
\hline 28 & 26,9 & 81,9 & 30,2 & 24,5 & 98,5 & 0,0 & 21,6 & 96,7 & 7,2 & 25,9 & & 0,0 \\
\hline 29 & 25,8 & - & 2,9 & 25,0 & 87,5 & 0,0 & 22,8 & 93,6 & 0,0 & & & \\
\hline 30 & 25,2 & 90,9 & 13,8 & 25,3 & 84,3 & 0,0 & 24,2 & 87,6 & 0,0 & & & \\
\hline 31 & - & i- & - & 26,1 & 91,8 & 0,0 & 24,3 & & 0,9 & & & \\
\hline Média & 26,3 & 87,1 & 191,1 & 25,2 & 90,9 & 196,2 & 25,4 & 88,0 & 121,8 & 25,3 & 88,7 & 96,5 \\
\hline
\end{tabular}


Apéndice 2 - temperatura $\left({ }^{\circ} \mathrm{C}\right)$ média, umidade relativa do ar $(\%)$ média e precipi tação diária para a região de Ilha Solteira - SP.

\begin{tabular}{|c|c|c|c|c|c|c|c|c|c|c|c|c|c|c|c|}
\hline \multirow[b]{2}{*}{ Dias } & \multicolumn{3}{|c|}{ Ouaubro/82 } & \multicolumn{3}{|c|}{ Noveribro/82 } & \multicolumn{3}{|c|}{ Dezenibro/82 } & \multicolumn{3}{|c|}{ Janeiro/83 } & \multicolumn{3}{|c|}{ Fevere1ro/83 } \\
\hline & $\begin{array}{c}\text { Tlerturero } \\
\text { tura }\end{array}$ & unilade & $\begin{array}{l}\text { Precipip. } \\
\text { tação }\end{array}$ & $\begin{array}{l}\text { Termpera } \\
\text { tura }\end{array}$ & Unidade & $\begin{array}{c}\text { Precipl } \\
\text { tacáo }\end{array}$ & $\begin{array}{c}\text { Terwera } \\
\text { tura }\end{array}$ & Unidade & $\begin{array}{l}\text { Precipị } \\
\text { tacão }\end{array}$ & $\begin{array}{l}\text { Tenpera } \\
\text { tura }\end{array}$ & Umidade & $\begin{array}{l}\text { Precilp } 1 \\
\text { taçao }\end{array}$ & $\begin{array}{l}\text { Temperä } \\
\text { tura }\end{array}$ & Unidade & $\begin{array}{l}\text { Freclpip } \\
\text { tacáo }\end{array}$ \\
\hline 1 & 27,0 & 81,0 & 0,0 & 28,9 & 79,6 & 0,0 & 24,6 & 93,8 & 5,2 & - & - & 17,8 & 25,0 & 96,9 & 10,4 \\
\hline 2 & 23,9 & 95,1 & 16,6 & - & - & 0,0 & - & - & 0,3 & - & - & 0,0 & 22,8 & 96,8 & 4,8 \\
\hline 3 & 23,9 & - & 0,0 & 30,8 & 77,8 & 0,0 & 24,7 & 92,1 & 0,0 & 25,9 & 87,3 & 1,3 & 20,8 & 96,5 & 2,0 \\
\hline 4 & 26,4 & 90,8 & 0,0 & 29,0 & 79,0 & 0,0 & - & 91,2 & 0,0 & 26,3 & 92,6 & 0,0 & - & 95,4 & 0,0 \\
\hline 5 & 25,0 & 85,4 & 25,4 & 27,2 & 86,6 & 7,8 & - & - & 0,0 & 25,8 & 95,4 & 3,8 & - & - & 0,0 \\
\hline 6 & 24,2 & 93,6 & 7,0 & - & 96,6 & 0,0 & 27,8 & 86,7 & 7,6 & 27,5 & 91,4 & 0,0 & - & - . & 0,0 \\
\hline 7 & 22,7 & 98,4 & 17,2 & - & - & 0,9 & 23,9 & 92,0 & 0,0 & 27,8 & 90,0 & 0,0 & 27,5 & 93,9 & 8,3 \\
\hline 8 & 22,9 & 98,4 & 32,8 & 28,1 & 82,7 & 0,0 & 26,2 & 80,6 & 0,0 & - & 98,4 & 0,0 & 24,2 & 96,9 & 12,4 \\
\hline 9 & 24,3 & 96,6 & 6,4 & 29,4 & 79,2 & 2,0 & 26,0 & 81,9 & 0,0 & - & - & 0,0 & 24,6 & 95,3 & 0,0 \\
\hline 10 & 23,4 & - & 0,0 & 27,6 & 91,0 & 18,2 & 25,7 & 89,2 & 1,3 & 25,8 & $98,5--$ & 12,7 & 25,7 & 98,5 & 6,8 \\
\hline 11 & 23,8 & 93,6 & 0,0 & 27,2 & 88,1 & 5,9 & - & 98,3 & 0,0 & 27,0 & 94,1 & 1,0 & - & 93,9 & 24,3 \\
\hline 12 & 27,1 & - & 0,0 & 27,2 & 86,6 & 0,0 & - & - & 3,5 & 26,8 & 97,0 & 0,0 & - & - & 0,0 \\
\hline 13 & 21,8 & 96,7 & 26,0 & - & 92,1 & 0,0 & 27,5 & 88,2 & 3,5 & - & 96,9 & 26,1 & - & - & 0,0 \\
\hline 14 & 19,6 & 87,2 & 0,0 & - & - & 13,4 & 25,8 & 90,8 & 0,0 & - & - & 0,0 & - & - & 31,2 \\
\hline 15 & 24,0 & 85,4 & 0,0 & - & - & 0,0 & 27,1 & 89,4 & 5,8 & - & 98,4 & 22,0 & - & - & 0,0 \\
\hline 16 & 25,1 & 93,0 & 0,0 & 25,6 & 90,8 & 5,5 & 25,8 & 95,4 & 3,0 & - & - & 0,0 & - & 81,7 & 0,0 \\
\hline 17 & 27,3 & - & 13,4 & 26,8 & 92,4 & 0,0 & 25,0 & 92,1 & 21,8 & 25,3 & 96,9 & 66,0 & 27,1 & 91,1 & 0,0 \\
\hline 18 & 22,4 & 96,7 & 5,7 & 28,1 & 86,9 & 0,0 & - & 98,4 & 0,0 & 26,9 & 94,0 & 31,6 & 27,8 & 92,5 & 0,0 \\
\hline 19 & 23,7 & 90,4 & 0,0 & 26,3 & 90,9 & 15,0 & - & - & 10,6 & 24,9 & 98,4 & 27,8 & - & 98,3 & 0,0 \\
\hline 20 & 26,6 & 86,6 & 1,5 & - & 95,1 & 0,0 & - & $\therefore \quad-$ & 0,0 & 25,5 & 93,9 & 20,5 & - & - & 0,0 \\
\hline 21 & 26,4 & 86,8 & 0,0 & - & - & 29,2 & 26,3 & 90,9 & 31,0 & 26,8 & 91,2 & 16,0 & 26,6 & 85,6 & 0,0 \\
\hline 22 & 26,8 & 83,4 & 0,0 & 25,5 & 93,8 & 2,0 & 23,9 & 96,8 & 14,0 & - & 98,4 & 0,0 & 27,3 & 94,0 & 0,0 \\
\hline 23 & 28,1 & - & 8,4 & 27,6 & 92,4 & 43,4 & 24,9 & 95,3 & 1,9 & - & - & 0,0 & - & 89,6 & 1,5 \\
\hline 24 & 26,4 & 89,5 & 0,0 & 26,1 & 92,3 & 0,0 & - & - & 0,0 & 26,8 & 85,6 & $0 ; 0$ & - & - & 0,0 . \\
\hline 25 & 26,3 & 90,9 & 13,6 & 28,0 & 89,7 & 6,6 & - & - & 0,0 & 27,9 & 87,2 & 0,0 & 28,4 & 92,4 & 8,3 \\
\hline 26 & 26,1 & 89,5 & $0 ; 0$ & 26,0 & 90,9 & 0,0 & - & - & 0,0 & 26,8 & 89,8 & $0 ; 0$ & - & 96,8 & 0,0 \\
\hline 27 & 26,9 & 86,9 & 0,0 & - & 95,2 & 0,0 & - & 96,8 & 0,0 & 27,2 & 91,2 & 0,0 & - & - & 0,0 \\
\hline 28 & 27,8 & 85,6 & 0,0 & - & - & 68,0 & 25,2 & 90,7 & $.10,9$ & 26,2 & 91,2 & 0,0 & 27,6 & 94,0 & 6,3 \\
\hline 29 & 27,9 & 89,4 & 0,0 & 24,3 & 93,7 & 0,2 & 23,5 & 96,8 & 0,0 & - & 98,4 & 8,0 & - & - & - \\
\hline 30 & 26,8 & - & 0,0 & 25,8 & 95,4 & 75,0 & - & - & 35,6 & - & - & 0,0 & - & - & - \\
\hline 31 & 27.0 & - & 0,0 & - & - & - & - & - & 0,0 & - & 98,4 & 72,0 & - & - & - \\
\hline Módia & 25,2 & 86,3 & 174,0 & 27,3 & 89,1 & 293,1 & 25,5 & 91,7 & 156,0 & 26,5 & 93,9 & $32 \varepsilon, 7$ & 25,8 & 93,5 & 116,3 \\
\hline
\end{tabular}


vêendice 3 - Valores de matéria orgãnica (\%), obtidos em diferentes profundidades do solo, referentes aos diversos tratamentos estudados no ano agrícola 1981/82.

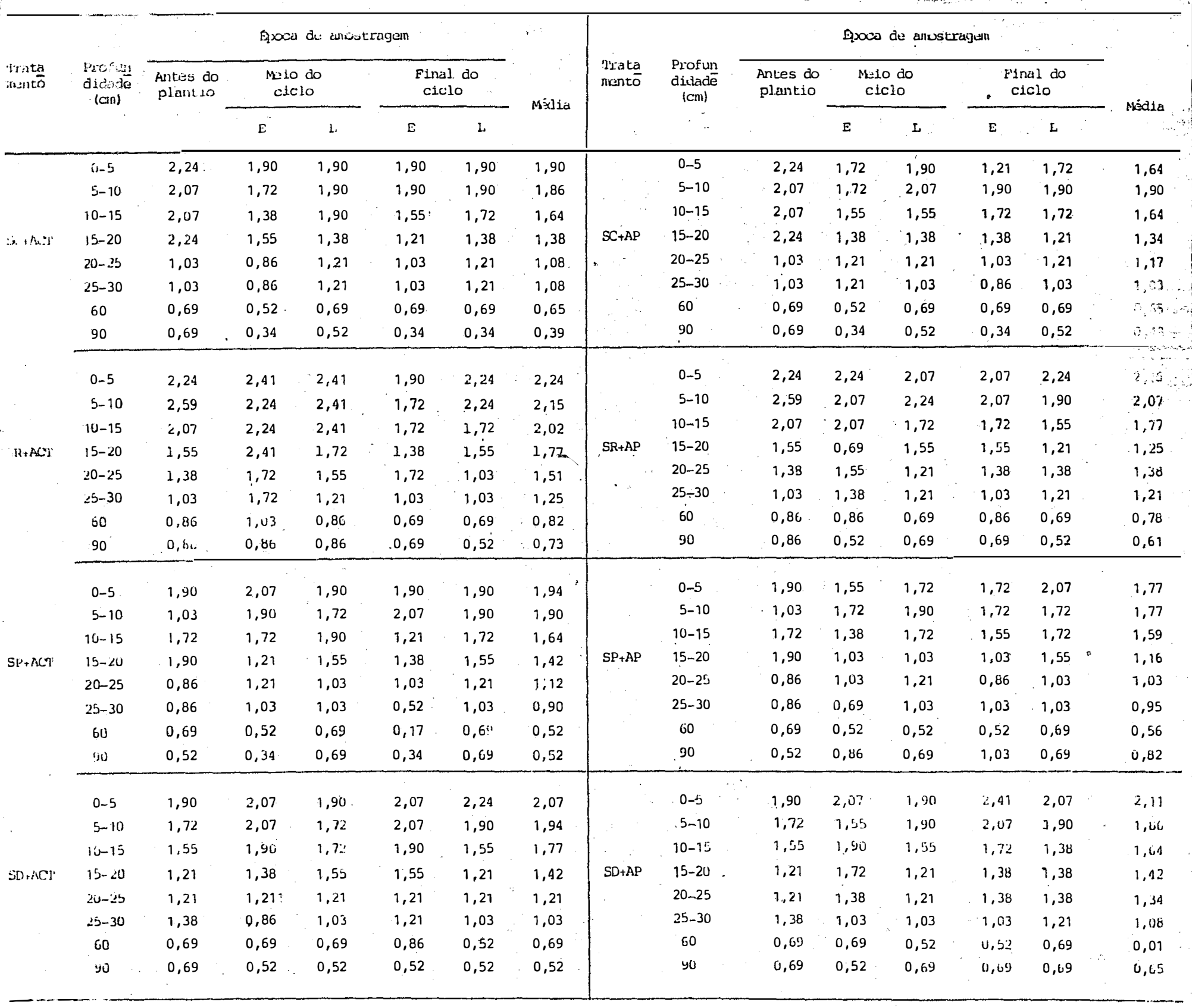


. Apêndice 04 - Valores de matéria orgânica (\%), obtidos en diferentes profundidades do solo, referentes aos diversos tratamentos estudados no ano agríco
$1982 / 83$.

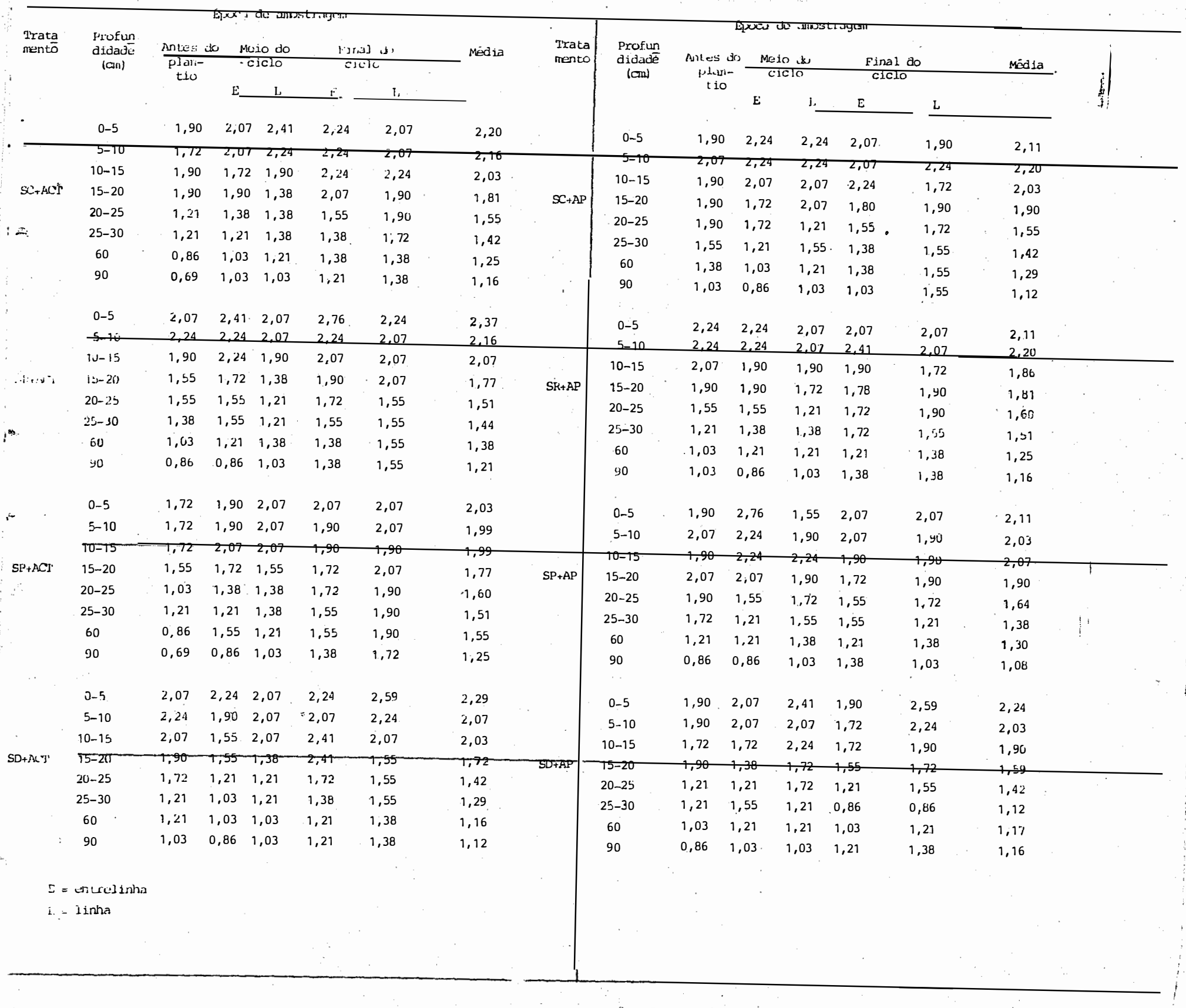


$x^{*}$

\begin{abstract}
Apêndice 5 - Valores de fósforo solúvel (ppm), abtidos em diferentes profundida des do solo, referentes aos diversos tratamentos estudados no ano agrícola 1981/82.
\end{abstract}

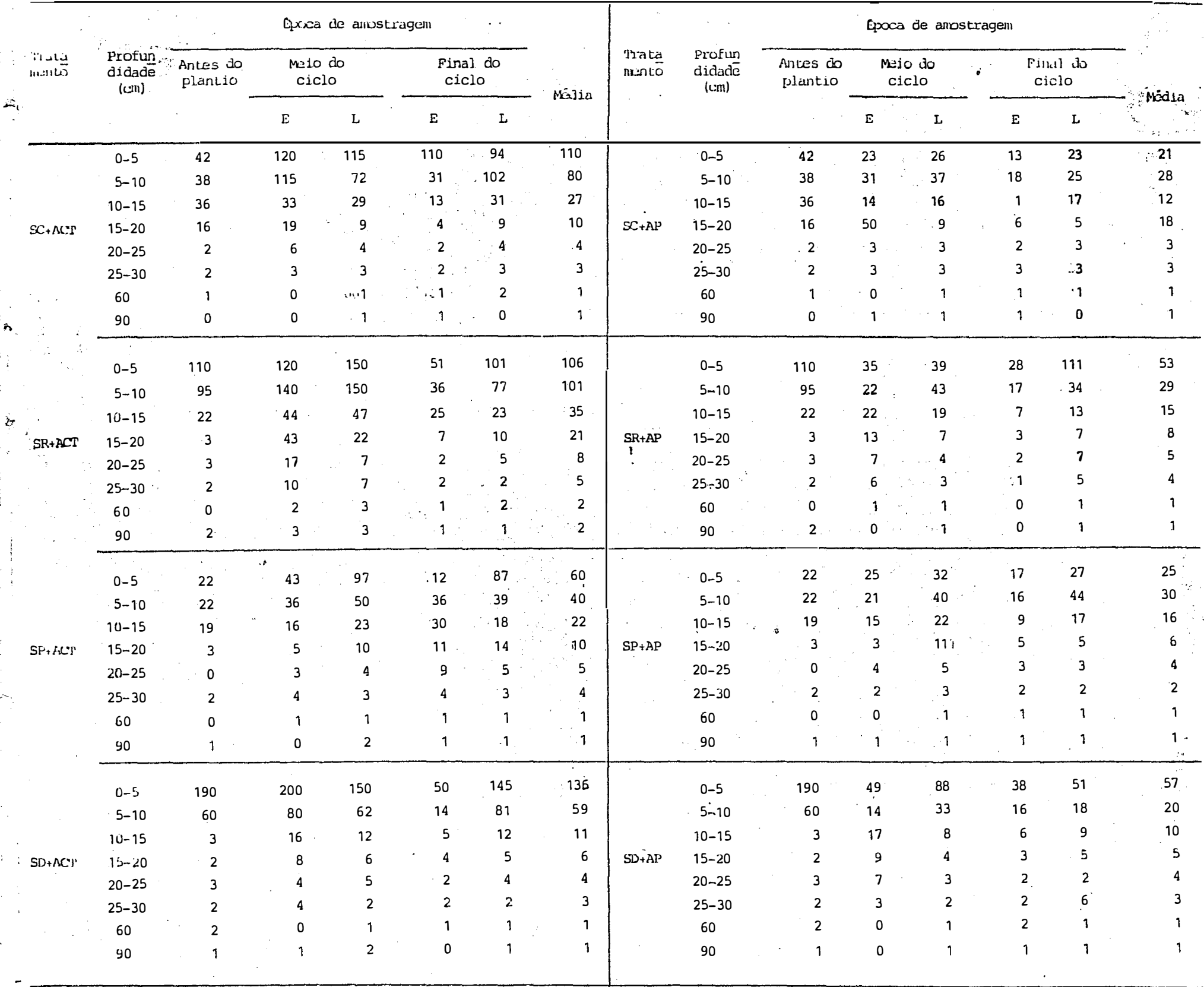

$E=$ entrelinha 
Apêndice 6 - Valores de fósforo solúvel (ppm), obtidos em diferentes profundida des do solo, referentes aos diversos tratamentos estudados no ano agrícola 1982/83.

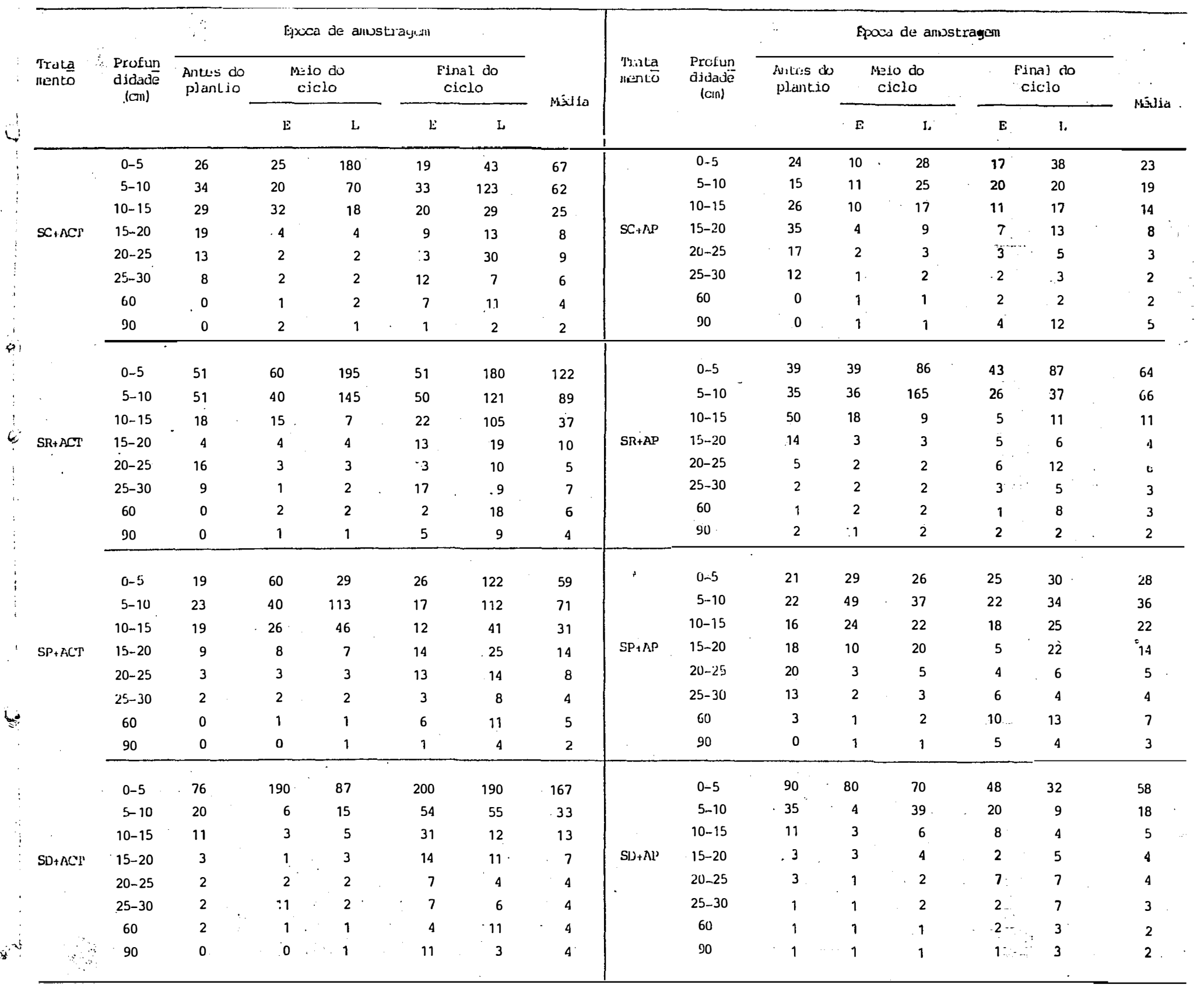


Apêndice 7 - Valores de potássio trocável (ppm), obtidos em diferentes profundi dades do solo, referentes aos diversos tratamentos estudados no ano agrícola 1981/82.

\begin{tabular}{|c|c|c|c|c|c|c|c|c|c|c|c|c|c|c|c|c|}
\hline \multirow{3}{*}{$\begin{array}{l}\text { Tratia } \\
\text { mento }\end{array}$} & \multirow{3}{*}{$\begin{array}{l}\text { Profun } \\
\text { asdade } \\
\text { (cin) }\end{array}$} & \multicolumn{5}{|c|}{ Exuca de anustray } & \multirow{3}{*}{ Mérlia } & \multirow{3}{*}{$\begin{array}{l}\text { Trata } \\
\text { mentó }\end{array}$} & \multirow{3}{*}{$\begin{array}{l}\text { Prof un } \\
\text { didade } \\
\text { (cni) }\end{array}$} & \multicolumn{6}{|c|}{ Fyxzid de inostrayon } & \multirow{3}{*}{ Média } \\
\hline & & \multirow{2}{*}{$\begin{array}{l}\text { Antes do } \\
\text { plank io }\end{array}$} & \multicolumn{2}{|c|}{$\begin{array}{l}\text { Meio do } \\
\text { ciclo }\end{array}$} & \multicolumn{2}{|c|}{$\begin{array}{l}\text { Final do } \\
\text { ciclo }\end{array}$} & & & & \multirow[t]{2}{*}{$\begin{array}{l}\text { Antes do } \\
\text { plantio }\end{array}$} & \multicolumn{2}{|c|}{$\begin{array}{l}\text { Maju do } \\
\text { ciclo }\end{array}$} & \multicolumn{2}{|c|}{$\begin{array}{l}\text { Fisial do } \\
\text { cjislo }\end{array}$} & & \\
\hline & & & E & Li & E. & L & & & & & E & L & E & $L$ & & \\
\hline \multirow{8}{*}{$S C+A C T$} & $0-5$ & 260 & 132 & 108 & 160 & 158 & 140 & \multirow{8}{*}{$S C+A P$} & $0-5$ & 260 & 84 & 96 & 100 & 136 & 3 & 104 \\
\hline & $5-10$ & 220 & 136 & 116 & 120 & 154 & 132 & & $5-10$ & 220 & 88 & 90 & 92. & 110 & & 95 \\
\hline & $10-15$ & 176 & 120 & 146 & $124^{\circ}$ & 118 & 127 & & $10-15$ & 176 & 64 & . 96 & 8 & 118 & & 72 \\
\hline & $15-20$ & 144 & 112 & 122 & 104 & 86 & 106 & & $15-20$ & 144 & 60 & 82 & 80 & 94 & & 79 \\
\hline & $20-25$ & 80 & 100 & 80 & 64 & 62 & 77 & & $20-25$ & 80 & 48 & 56 & 80 & 68 & $i$ & 53 \\
\hline & $25-30$ & 60 & 56 & 76 & 52 & 40 & 56 & & $25-30$ & 60 & 40 & 52 & 40 & 23 & & $39 \therefore$ \\
\hline & 60 & 12 & 4 & 12 & 16 & 10 & 11 & & 60 & 12 & 0 & 14 & 16 & 12 & & 11 \\
\hline & 90 & 8 & 4 & 8 & 4 & 10 & 7 & & 90 & 8 & 4 & 10 & 4 & 10 & & $\therefore 7$ \\
\hline \multirow{5}{*}{$\mathrm{SR}+\mathrm{ACT}$} & $0-5$ & 208 & 160 & 140 & 164 & 142 & 152 & \multirow{3}{*}{ 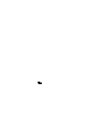 } & $0-5$ & 208 & 184 & 130 & 160 & 132 & & 152 \\
\hline & $5-10$ & 312 & 144 & 160 & 120 & 172 & 149 & & $5-10$ & 312 & 132 & 140 & 128 & 128 & & 132 \\
\hline & $101-15$ & 100 & 160 & 170 & 116 & 150 & 149 & & $10-15$ & 100 & 104 & 128 & 104. & 118 & & 114 \\
\hline & $15-20$ & 60 & 224 & 158 & 88 & 128 & 150 & \multirow[t]{5}{*}{$S R+A P$} & $15-20$ & 60 & 92 & 108 & $\therefore 96$ & 90 & & 97 \\
\hline & $20-25$ & 32 & 112 & 124 & 68 & 96 & 100 & & $20-25$ & 32 & 76 & 88 & 56 & 96 & & 79 \\
\hline \multirow{5}{*}{. } & $25-30$ & 24 & 140 & 70 & 48 & 96 & 89 & & $25-30$ & 24 & 56 & 56 & 36 & 68 & & 54 \\
\hline & 60 & 8 & 12 & 18 & 12 & 16 & 15 & & 60 & 8 & 8 & 6 & 12 & 12 & & 10 \\
\hline & $90^{\circ}$ & 24 & 24 & 20 & 8 & 10 & 16 & & 90 & 24 & 8 & 2 & 8 & 8 & & 7 \\
\hline & $0-5^{\prime}$ & 132 & 104 & 88 & 148 & 115 & 114 & \multirow{8}{*}{$S P_{1} A P$} & 0.5 & 132 & 64 & 90 & 104 & 114 & & 93 \\
\hline & $5-10$ & 160 & 128 & 100 & 136 & 146 & 128 & & $5-10$ & 160 & 92 & 100 & 88 & 116 & & 99 \\
\hline \multirow{9}{*}{$\mathrm{Sp}^{\mathrm{p}}+\mathrm{ACP}$} & $19-15$ & 104 & 100 & 102 & 124 & 134 & 115 & & $10-15$ & 104 & 88 & 110 & 112 & 113 & & 106 \\
\hline & $15-20$ & 68 & 88 & 92 & 96 & 116 & 98 & & $15-20$ & 68 & 64 & 86 & 112 & 76 & & 85 \\
\hline & $20-25$ & 52 & 80 & 68 & 176 & 64 & 97 & & $20-25$ & 52 & 56 & 68 & 76 & 64 & & 66 \\
\hline & $25-30$ & 36 & 96 & 62 & 40 & 48 & 62 & & $25-30$ & 36 & 48 & 50 & 48 & 50 & & 49 \\
\hline & 6i) & 12 & 16 & 22 & 24 & 22 & 21 & & 60 & 12 & 0 & 8 & 16 & 17 & & 10 \\
\hline & 90 & 12 & 0 & 10 & 12 & 10 & 8 & & 90 & 12 & 8 & 10 & 8 & 10 & & 9 \\
\hline & $0-5$ & 284 & 172 & 110 & 152 & 144 & 145 & & $0-5$ & 284 & 96 & 154 & 192 & 142 & & 146 \\
\hline & $5-10$ & 116 & 104 & 108 & 104 & 116. & 108 & & $5-10$ & 116 & 40 & 130 & 168 & 108 & & 112 \\
\hline & $10-15$ & 40 & 304 & 78 & 80 & 98 & 140 & & $10-15$ & 40 & 60 & 100 & 120 & 84 & & 91 \\
\hline \multirow[t]{5}{*}{$\mathrm{SD}+\mathrm{ACI}$} & $15-20$ & 28 & 60 & 46 & 64 & 80 & 63 & $\mathrm{SD}+\mathrm{Al}$ & $15-20$ & 28 & 40 & 100 & 68 & 68 & & 69 \\
\hline & $20-25$ & 24 & 48 & 50. & 40 & 58 & 49 & & $20-25$ & 24 & 40 & 142 & 56 & 40 & & 45 \\
\hline & $25-30$ & 16 & 48 & 32 & 40 & 36 & 39 & & $25-30$ & 16 & 24 & 24 & 32 & 56 & & 34 \\
\hline & 60 & 12 & 8 & 12 & 16 & 28 & 16 & & 60 & 12 & 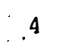 & 6 & 12 & 16 & & 10. \\
\hline & 90 & 16 & 4 & 8 & 8 & 30 & 13 & & $90^{\circ}$ & 16 & 4 & 6 & 48 & 38 & & 24 \\
\hline
\end{tabular}

$\because \mathrm{E}=$ entrelinha

$L=$ linha 
Apêndice 8 - Valores de potássio trocável (ppm), obtidos em diferentes profundi dades do solo, referentes aos diversos tratamentos estudados no ano agrícola 1982/83.

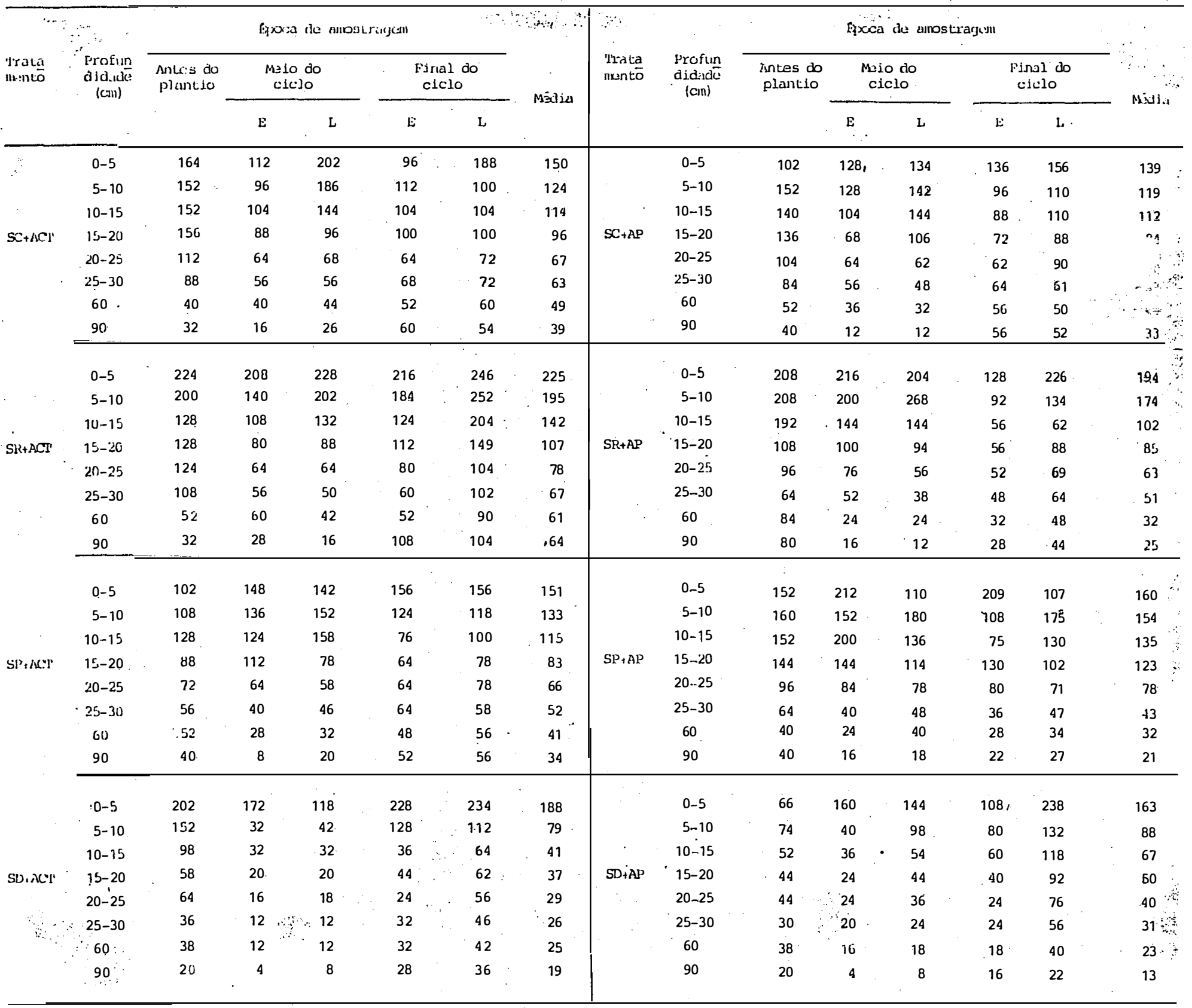

$E=$ entiel.irdia

$L=1$ jinh 
Apêndice 9 - Valores de cálcio + magnésio trocável (e.mg/100 ml de TFSA), ab:tidos em diferentes profundidades do solo, referentes aos diversos tratamentos estudados no ano agrícola 1981/82.

\begin{tabular}{|c|c|c|c|c|c|c|c|c|c|c|c|c|c|c|c|}
\hline \multirow{3}{*}{$\begin{array}{l}\text { Wata } \\
\text { nentó }\end{array}$} & \multirow{3}{*}{$\begin{array}{l}\text { Profun } \\
\text { didade } \\
\text { (cni) }\end{array}$} & \multicolumn{5}{|c|}{ 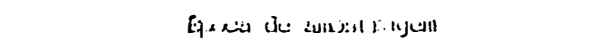 } & \multirow{3}{*}{ Mália } & \multirow{3}{*}{$\begin{array}{l}\text { 'Tratia } \\
\text { mantōo }\end{array}$} & \multirow{3}{*}{$\begin{array}{l}\text { profun } \\
\text { didudade } \\
\text { (c:m) }\end{array}$} & \multicolumn{5}{|c|}{ Fiqoca de anbstragjan } & \multirow{3}{*}{$\begin{array}{c}\therefore \\
\therefore \\
\text { Midso } \\
\therefore \therefore\end{array}$} \\
\hline & & \multirow[t]{2}{*}{$\begin{array}{l}\text { Avites do } \\
\text { plantio }\end{array}$} & \multicolumn{2}{|c|}{$\begin{array}{c}\text { Meio do } \\
\text { ciclo }\end{array}$} & \multicolumn{2}{|c|}{$\begin{array}{l}\text { Pinal do } \\
\text { cicilo }\end{array}$} & & & & \multirow[t]{2}{*}{$\begin{array}{l}\text { Antes do } \\
\text { plantio }\end{array}$} & \multicolumn{2}{|c|}{$\begin{array}{l}\text { Meio do } \\
\text { ciclo }\end{array}$} & \multicolumn{2}{|c|}{$\begin{array}{l}\text { Final do } \\
\text { ctclo }\end{array}$} & \\
\hline & & & E & L & E: & I. & & & & & $\mathrm{E}$ & I & E & L & \\
\hline \multirow{8}{*}{$S C+A C H$} & $0-5$ & 3,8 & 3,3 & 4,3 & 4,2 & 4,2 & 4,0 & \multirow{8}{*}{$S C+A P$} & $0-5$ & 3,8 & 2,5 & 3,8 & 2,8 & 4,9 & 3,5 \\
\hline & $5-10$ & 3,2 & 3,5 & 3,1 & 3,4 & $4 ; 9$ & 3,7 & & $5-10$ & 3,2 & 2,3 & 3,8 & 3,6 & 3,6 & 3,3 \\
\hline & $10-15$ & 3,1 & 2,4 & 3,8 & 2,9 & 4,0 & 3,3 & & $10-15$ & 3,1 & 1,5 & 2,2 & 2,6 & 2,2 & 2,1 \\
\hline & $15-20$ & 3,3 & 2,0 & 1,8 & 0,6 & 2,7 & 1,8 & & $15-20$ & 3,5 & 1,3 & 1,5 & 1,8 & 1,5 & 1,5 \\
\hline & $20-25$ & 2,2 & 2,0 & 1,8 & 1,1 & 1,8 & 1,7 & & $20-25$ & 2,2 & 1,3 & 1,3 & 1,2 & 1,7 & 1,4 \\
\hline & $25-30$ & 2,0 & 1,1 & 1,8 & 1,4 & 1,4 & 1,4 & & $25-30$ & 2,0 & 1,3 & 1,1 & 0,8 & 1,7 & 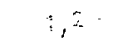 \\
\hline & 60 & 1,4 & 0,8 & 0,9 & 0,7 & 1,5 & 1,0 & & 60 & 1,4 & 0,6 & 1,8 & 0,7 & 1,0 & ני. \\
\hline & 90 & 1,2 & 0,8 & 0,7 & 1,4 & 0,7 & 0,9 & & 90 & 1,2 & 0,9 & 1,4 & 0,9 & 0,5 & $\because,:$ \\
\hline \multirow{5}{*}{$\begin{array}{c}4 \\
S \\
S R+A C T\end{array}$} & $0-5$ & 5,5 & 5,4 & 5,8 & 6,3 & 5,9 & 5,9 & \multirow{8}{*}{$\mathrm{SR}+\mathrm{AP}$} & $0-5$ & 5,5 & 4,8 & 4,3 & 4,8 & 5,3 & 4,3 \\
\hline & $5-10$ & 4,4 & 4,6 & 5,1 & 4,8 & 5,6 & 5,0 & & $5-10$ & 4,4 & 2,9 & 3,9 & 3,6 & 4,0 & 3,6 \\
\hline & $10-15$ & 3,3 & 3,6 & 3,6 & 3,4 & 3,0 & 3,4 & & $10-15$ & 3,3 & 2,9 & 2,3 & 1,6 & 2,3 & 2,3 \\
\hline & $15-20$ & 2,4 & 3,5 & 2,9 & 2,3 & 2,4 & 2,8 & & $15-20$ & 2,4 & 2,2 & 1,6 & 1,4 & 1,5 & 1,7 \\
\hline & $2 v-25$ & 2,2 & 2,9 & 2,8 & 1,4 & 1,4 & 2,1 & & $20-25$ & 2,2 & 1,6 & 0,9 & 3,2 & 1,2 & 1,7 \\
\hline \multirow{3}{*}{ 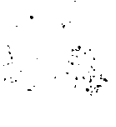 } & $25-30$ & 1,8 & 2,1 & 2,1 & 1,5 & 2,0 & 1,9 & & $25-30$ & 1,8 & 1,8 & 1,3 & 1,1 & 1,4 & 1,4 \\
\hline & 60 & 1,7 & 1,7 & 1,0 & 1,1 & 1,0 & 1,2 & & 60 & 1,7 & 1,1 & 0,9 & 0,4 & 0,9 & 0,8 \\
\hline & 90 & 1,3 & 1,6 & 2,3 & 0,8 & 0,3 & 1,3 & & 90 & 1,3 & 0,6 & 0,4 & 0,2 & 1,1 & 0,6 \\
\hline \multirow{3}{*}{$\because:$} & $0-5$ & 1,8 & 2,5 & 2,2 . & 2,8 & 3,3 & 2,7 & \multirow{8}{*}{$\mathrm{SP}_{+}+\mathrm{SP}$} & $0-5$ & 1,8 & 4,2 & 3,5 & 2,6 & 4,2 & 3,6 \\
\hline & $5-10$ & 2,1 & 2,6 & 2,4 & 2,1 & 3,5 & 2,7 & & $5-10$ & 2,1 & 3,6 & 3,8 & 2,4 & 4,0 & $3,5^{\circ}$ \\
\hline & $10-15$ & 2,0 & 1,6 & 2,4 & 1,7 & 3,1 & 2,2 & & $3(1)-15$ & 2,0 & $1 ; 5$ & 3,0 & 1,8 & 3,4 & 2,4 \\
\hline \multirow[t]{8}{*}{$\mathrm{SH}^{2}+\mathrm{ACH}^{\prime}$} & $15-20$ & 1,4 & 1,2 & 1,7 & 1,6 & 2,2 & 1.7 & & $15-20$ & 1,4 & 1,2 & 2,5 & 2,1 & 1,9 & 1,9 \\
\hline & $20-25$ & 1,6 & 1,1 & 1,5 & 1,2 & 1,8 & 1,4 & & 20.25 & 1,6 & 1,2 & 1,4 & 0,8 & 2,0 & 1,4 \\
\hline & $25-30$ & 1,8 & 0,9 & 1,4 & 1,1 & 1,3 & 1,2 & & $25-30$ & 1,8 & 1,0 & 1,3 & 0,8 & 1,3 & 1,1 \\
\hline & 60 & 1,6 & 0,0 & 1,2 & 2,1 & 1,5 & 1,2 & & 60 & 1,6 & 0,6 & 1,0 & 0,8 & 0,6 & 0,8 \\
\hline & 90 & 1,2 & 0,6 & $0 ; 9$ & 0,7 & 0,2 . & 0,6 & & 90 & 1,2 & 0,9 & 0,8 & 0,6 & 0,4 & 0,7 \\
\hline & $0-5$ & 5,8 & 7,0 & 5,0 & 5,1 & 6,1 & 5,8 & \multirow{8}{*}{$S D+A P$} & $0-5$ & 5,8 & 4,5 & 4,1 & 5,0 & 5,4 & 4,8 \\
\hline & $5-10$ & 5,3 & 4,0 & 3,7 & 3,0 & 4,0 & 3,7 & & $5-10$ & 5,3 & 3,4 & 3,7 & 3,4 & 3,3 & 3,5 \\
\hline & $10-15$ & 3,3 & 2,3 & 2,3 & 2,0 & 2,9 & 2,4 & & 10-15 & 3,3 & 3,5 & 1,9 & 2,3 & 2,8 & 2,6 \\
\hline \multirow[t]{5}{*}{$\sin +A^{\prime}$} & $15-20$ & 2,7 & 2,1 & 1,5 & $.1,4$ & 2,0 & 1,8 & & $15-20$ & 2,7 & 1,9 & 1,8 & 1,8 & 1,8 & 1,8 \\
\hline & $20-25$ & 2,4 & 1,4 & 1,7 & 1,4 & 1,9 & 1,6 & & $20-25$ & 2,4 & 1,5 & 1,7 & 1,8 & 1,9 & 1,7 \\
\hline & $25-30$ & 3,0 & 1,8 & 1,4 & 0,9 & 1,6 & 1,4 & & $25-30$ & 3,0 & 0,9 & 1,4 & 1,4 & 1,9 & $1,4 \ldots$ \\
\hline & 60 & 1,3 & 1,4 & 0,9 & 0,3 & 0,5 & 0,8 & & 60 & 1.3 & 0,6 & 0,5 & 0,7 & 0,7 & 0,6 \\
\hline & 90 & 0,9 & 0,8 & 0,5 & 0,0 & 1,5 & 0,3 & & 90 & 0,9 & 0,2 & 0,7 & 0,6 & 1,5 & 0,8 \\
\hline
\end{tabular}

$E=$ ontucilinda 


$$
\text { Apêndice 10 - Valores de cālcìo + magnésio trocáveis (e.mg/100 ml de TFSA), ab- }
$$

\begin{tabular}{|c|c|c|c|c|c|c|c|c|c|c|c|c|c|c|}
\hline \multirow{3}{*}{$\begin{array}{l}\text { lrata: } \\
\text { livento: }\end{array}$} & \multirow{3}{*}{$\begin{array}{l}\text { Profun } \\
\text { didade } \\
\therefore(\text { cin })^{\cdots}\end{array}$} & \multicolumn{5}{|c|}{ - Foxid cje iutustrayidn } & \multirow{3}{*}{ Mżala } & \multirow{3}{*}{$\begin{array}{l}\text { Irats } \\
\text { mento }\end{array}$} & \multirow{3}{*}{$\begin{array}{l}\text { Profun } \\
\text { didiade } \\
\text { (cni) }\end{array}$} & \multicolumn{4}{|c|}{ Guca de antustragen } & \multirow{3}{*}{ Malia } \\
\hline & & \multirow{2}{*}{$\begin{array}{l}\text { Autus do } \\
\text { planitio }\end{array}$} & \multicolumn{2}{|c|}{$\begin{array}{l}\text { Meio do } \\
\text { ciclo }\end{array}$} & \multicolumn{2}{|c|}{$\begin{array}{l}\text { 1. mal do } \\
\text { cicjo }\end{array}$} & & & & \multirow[t]{2}{*}{$\begin{array}{l}\text { Antess (k) } \\
\text { plintio }\end{array}$} & $\begin{array}{c}\text { Melo do } \\
\text { ciclo }\end{array}$ & \multicolumn{2}{|c|}{$\begin{array}{l}\text { Pinkil de } \\
\text { cicles }\end{array}$} & \\
\hline & & & E & L & $E$ & I. & & & & & $\dot{E}$ & E' & $L$ & \\
\hline \multirow[t]{3}{*}{ - } & $0-5$ & 4,8 & 2,8 & 4,3 & 4,1 & 3,3 & 3,6 & \multirow{8}{*}{$S C+A P$} & $0-5$ & 4,2 & 3,2 & 3,7 & 3,8 & 3,6 \\
\hline & $5-10$ & 4,2 & 2,5 & 3,9 & 3,1 & 3,5 & 3,3 & & $5-10$ & 4,7 & 3,4 & 3,4 & 4,1 & 3,7 \\
\hline & $10-15$ & 2,7 & 3,1 & 2,4 & 2,7 & 3,2 & 2,9 & & $10-15$ & 5,2 & 2,6 & 2,7 & 3,8 & 3,2 \\
\hline \multirow{8}{*}{$S C+A C r$} & $15-20$ & 4,4 & 1,2 & 1,5 & 1,7 & 2,9 & 1,8 & & $15-20$ & 4,2 & 1,5 & 2,3 & 3,3 & 2,4 \\
\hline & $20-25$ & 2,7 & 1,0 & 1,1 & $.1,2$ & 2,5 & 1,5 & & $20-25$ & 2,3 & 1,1 & 1,2 & 2,2 & 1,6 \\
\hline & $25-30$ & 2,8 & 1,1 & 1,3 & 1,3 & 2,2 & 1,5 & & $25-30$ & 2,9 & 1,1 & 1,2 & 1,0 & 1,1 \\
\hline & 60 & 1,1 & 0,9 & 0,9 & 1,4 & 1,5 & 1,2 & & 60 & 1,2 & 0,7 & 0,9 & 1,1 & 1,0 \\
\hline & $y()$ & 1,1 & 1,6 & 0,4 & 1,1 & 1,6 & 1,2 & & 90 & 2,2 & 0,5 & 1,4 & 1,8 & 1,1 \\
\hline & ט & 5,7 & 5,4 & 5,5 & 4,2 & 4,4 & 4,9 & \multirow{8}{*}{$S R+A P$} & $0-5$ & 5,9 & 3,5 & 4,4 & 3,4 & $\therefore-$ \\
\hline & $5-10$ & 4,0 & 5,4 & 4,6 & 3,5 & 3,7 & 4,3 & & $5-10-$ & 4,1 & 3,1 & 5,4 & 5,2 & $9: 2$ \\
\hline & $111-15$ & 3,7 & 2,3 & 2,1 & 1,9 & 3,0 & 2,3 & & $10-15$ & 5,5 & 1,9 & 2,2 & 3,2 & 2,2 \\
\hline \multirow[t]{5}{*}{$\mathrm{SR}+\mathrm{ACl}$} & $15-20$ & 2,7 & 1,2 & 1,1 & 1,8 & 2,6 & 1,7 & & $15-20$ & 3,9 & 1,4 & 1,6 & 2,9 & 1.8 \\
\hline & $20-25$ & 3,6 & 1,2 & 0,8 & 1,3 & 1,2 & 1,1 & & $20-25$ & 2,3 & 1,0 & 1,2 & 3,5 & 1,8 \\
\hline & $25-30$ & 2,9 . & 1,1 & 1,2 & 1,1 & 1,2 & 1,2 & & $25-30$ & 2,1 & 1,0 & 1,2 & 1,5 & 1,2 \\
\hline & 60 & 0,9 & 0,6 & 1,4 & 1,1 & 1,5 & 1,2 & & 60 & 1,9 & 1,0 & 1,1 & 1,1 & 1,0 \\
\hline & 90 & 1,1 & 0,6 & 0,6 & 1,1 & 1,2 & 0,9 & & 90 & 1,5 & 0,9 & 1,2 & 1,2 & 1,1 \\
\hline & $0-5$ & 3,1 & 2,5 & 2,5 & 3,5 & 3,7 & 3,1 & \multirow{8}{*}{$\mathrm{SP}+\lambda \mathrm{P}$} & $0-5$ & 3,9 & 3,5 & 3,8 & 3,9 & 3,8 \\
\hline & $5-10$. & 3,2 & 2,5 & 3,0 & 3,2 & $3,5^{\prime}$ & 3,1 & & $5-10$ & 4,0 & 3,2 & 3,8 & 4,0 & 3,8 \\
\hline & $10-15$ & 3,4 & 3,0 & 2,5 & 2,3 & 3,9 & 2,9 & & $10-15$ & 6,1 & 3,2 & 3,9 & 3,8 & 3,7 \\
\hline \multirow[t]{3}{*}{$S 1 \cdot A C P$} & $15-20$ & 2,2 & 2,4 & 1,4 & 2,2 & 3,0 & 2,3 & & $15-20$ & 3,8 & 3,1 & 2,0 & 3,3 & 3,0 \\
\hline & $2 u-25$ & 2,0 & 0,9 & 1,3 & 1,6 & 2,4 & 1,6 & & $20-25$ & 3,7 & 2,1 & $1,3^{n}$ & 2,1 & 1,9 \\
\hline & $25-30$ & 1,0 & 1,4 & 0,8 & 1,4 & 2,1 & 1,4 & & $25-30$ & 3,2 & 1,2 & 1,8 & 1,2 & 1,3 \\
\hline \multirow{5}{*}{$\cdot$} & 60 & 2,3 & 1,0 & 1,2 & 1,3 & 1,9 & 1,4 & & 60 & 2,1 & 0,7 & 1,6 & 1,1 & 1,0 \\
\hline & 90 & 0,9 & 0,7 & 0,7 & 1,2 & 1,5 & 1,0 & & 90 & 4,0 & 0,8 & 1,4 & 1,4 & 1,0 \\
\hline & $\therefore u-5$ & 5,7 & 5,1 & 4,1 & 5,0 & 4,4 & 4,7 & & $0-5$ & 6,8 & 4,6 & 4,0 & 4,1 & 4,4 \\
\hline & $\because 5-10$ & 4,3 & 2,5 & 2,8 & 3,1 & 3,0 & $2,9$. & . & $5-10$ & 5,4 & 5,1 & 2,4 & 2,7 & 3,5 \\
\hline & $10-15$ & 2,8 & 0,8 & 2,8 & 2,4 & 1,7 & 1,9 & $\cdot$ & $10-15$ & 5,3 & 1,4 & 2,9 & 1,8 & 2,0 \\
\hline \multirow[t]{5}{*}{ SD+ACT } & $15-20$ & 1,9 & 1,0 &, 12 & 1,6 & 1,6 & 1,4 & $S D+A P$ & $15-20$ & 3,3 & 1,4 & 1,8 & 1,5 & 1,5 \\
\hline & $20-25$ & 1,4 & 1,3 & 1,2 & 1,4 & 1,5 & 1,4 & . & $20-25$ & 1,9 & 7,4 & 0,9 & 1,3 & 1,1 \\
\hline & $25-30$ & 1,3 & 0,8 & 1,3 & 1,5 & 1,2 & 1,2 & & $25-30$ & 0,8 & 1,6 & 1,1 & 1,4 & 1,3 \\
\hline & 60 & 2,4 & 0,5 & $1,1 \ldots$ & 1,4 & 1,3 & 1,1 & & 60 & 1,3 & 1,4 & 1,2 & 1,1 & 1,2 \\
\hline & $\because 90$ & $\begin{array}{l}1,5 \\
\because \quad\end{array}$ & 0,2 & 0,4 & 1,7 & 1,2 & 0,9 & & 90 & 1,5 & 0,5 & 1,2 & 1,1 & 0,9 \\
\hline
\end{tabular}
sos tratamentos estudados no ano agrícola 1982/83.

$E=$ entrelinha

$L=I L$ Lia 


\section{Apéndice 11 - Valores de pH em $\mathrm{H}_{2} \mathrm{O}$, obtidos em diferentes profundidades do solo referentes aos diversos tratamentos estudados no ano $\because \because$ agrícola 1981/82.}

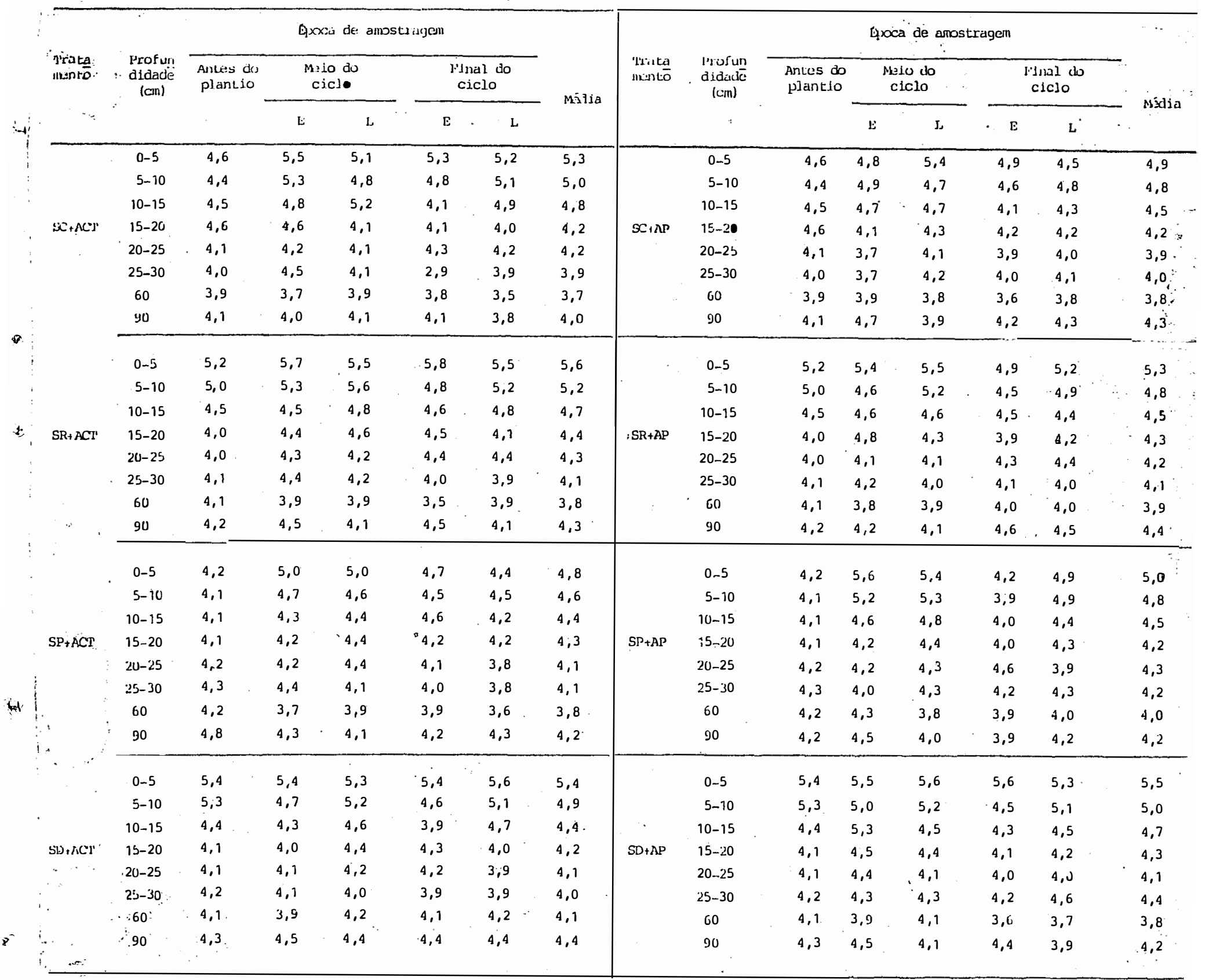

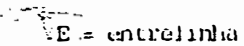
L - Jindis 
Apéndice 12 - Valores de $\mathrm{pH}$ em $\mathrm{H}_{2}=$, obtidos em diferentes profundidade do solo, referentes aos diversos tratamentos estudados no ano . . . agrícola 1982/83.

\begin{tabular}{|c|c|c|c|c|c|c|c|c|c|c|}
\hline \multirow[b]{2}{*}{$\begin{array}{l}\text { Trata } \\
\text { mentö }\end{array}$} & \multirow{3}{*}{$\begin{array}{l}\text { Profun } \\
\text { didade } \\
\text { (ciil) }\end{array}$} & \multicolumn{3}{|c|}{ i: } & \multirow{3}{*}{ Mkalia } & \multirow{3}{*}{$\begin{array}{l}\text { Irinta } \\
\text { Mranto }\end{array}$} & \multirow{3}{*}{$\begin{array}{l}\text { Profuns } \\
\text { dtclexde } \\
\text { (cin) }\end{array}$} & \multicolumn{3}{|c|}{ Apuca de anostrargim } \\
\hline & & $\begin{array}{l}\text { l:ntes do } \\
\text { filantio }\end{array}$ & $\begin{array}{c}M=10 \text { do } \\
\text { t:iclo }\end{array}$ & $\begin{array}{l}\text { Final do } \\
\text { ciclo }\end{array}$ & & & & $\begin{array}{l}\text { Antus:s do } \\
\text { plintitio }\end{array}$ & $\begin{array}{l}\text { Maio do } \\
\text { ciclo }\end{array}$ & $\begin{array}{l}\text { lidial do } \\
\text { cucilo }\end{array}$ \\
\hline & & & E & $L$ & & & & & L & L \\
\hline
\end{tabular}

\begin{tabular}{lllllll|}
\hline $0-5$ & 4,8 & 4,8 & 5,1 & 5,4 & 5,0 & 5,1 \\
$5-10$ & 4,9 & 4,5 & 5,0 & 5,2 & 5,0 & 4,9
\end{tabular}

$\mathrm{SC}+\mathrm{hCS}$

10- $15 \quad 5,0 \quad 3,5$

$15-20 \quad 5,0 \quad 4,4$

$\begin{array}{llllll}4,45 & 4,4 & 4,2 & 4,3 & 4,9 & 4,5\end{array}$

\begin{tabular}{|c|c|c|c|}
\hline U-25 & 4,4 & 4,2 & 4,2 \\
\hline & 9 & ( & 4,2 \\
\hline
\end{tabular}

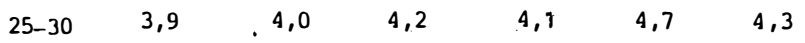

$\begin{array}{lllllll}60 & 3,4 & 3,9 & 3,8 & 4,2 & 4,3 & 4,1\end{array}$

.

$0-5$

$4,6 \quad 4,9$

5,0

$\begin{array}{ll}5,1 & 5,4 \\ 5,0 & 5,3\end{array}$

$5,0 \quad 4,9$

5,2

$4,7 \quad 4,7$

5,2
5,1

$5,1 \quad 5,1$

$\begin{array}{lll}4,7 & 4,7 & 5,1 \\ 4,7 & 4,2 & 4,6\end{array}$

$4,2 \div 4,1$

4,1

$4,9 \cdot 4,7$

$3,8 \quad 4,2$

4,2

25-30

\begin{tabular}{lllllll|l}
90 & 3,5 & 3,8 & 3,7 & 4,4 & 4,2 & 4,0 & 90 \\
\hline $0-5$ & 5,3 & 5,5 & 5,4 & 5,2 & 5,2 & 5,3 & 0
\end{tabular}

$\begin{array}{lllllll}0-5 & 5,3 & 5,5 & 5,4 & 5,2 & 5,2 & 5,3 \\ 5-10 & 5,1 & 5,4 & 5,4 & 4,9 & 5,3 & 5,3\end{array}$

$S R+A C T$

$\begin{array}{lllllll}10-15 & 4,6 & 4,6 & 4,8 & 4,5 & 5,0 & 4,7\end{array}$

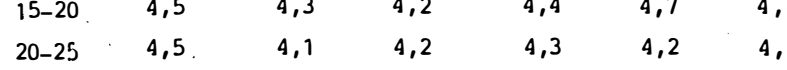

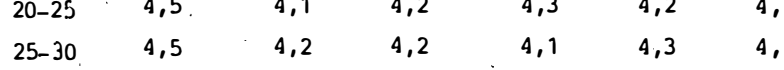

$\begin{array}{lllllll}60 & 3,7 & 4,2 & 4,3 & 4,2 & 4,1 & 4,2 \\ 90 & 3,5 & 3,9 & 4,1 & 4,3 & 4,2 & 4,1\end{array}$

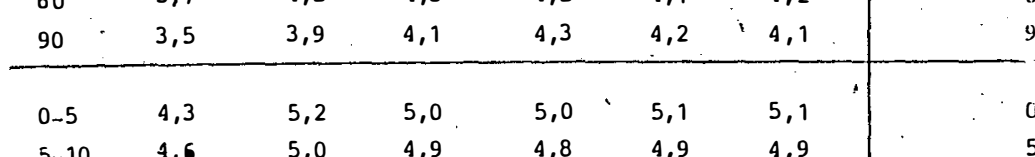

$\begin{array}{rrrrrrr}0-5 & 4,3 & 5,2 & 5,0 & 5,0 & 5,1 & 5, \\ 5-10 & 4,6 & 5,0 & 4,9 & 4,8 & 4,9 & 4, \\ 10-15 & 4,5 & 4,8 & 4,9 & 4,5 & 5,2 & 4,\end{array}$

$\begin{array}{llllllll}\text { SP } \\ \text { H.CT } & 15-20 & 4,2 & 4,5 & 4,4 & 4,2 & 4,8 & 4,5\end{array}$

$\begin{array}{rrrrrrr}20-25 & 4,1 & 4,3 & 4,2 & 4,1 & 4,5 & 4,3\end{array}$

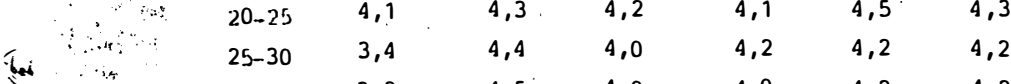

is

$$
60
$$

$\begin{array}{lllllll}60 & 3,8 & 4,5 & 4,0 & 4,0 & 4,2 & 4, \\ 90 & 3,3 & 4,2 & 4,0 & 4,1 & 4,2 & 4,\end{array}$

$S D+A C T$

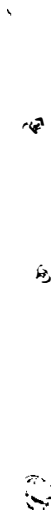


Apéndice 13 - Valores de C.T.C. ao pH 7,0 (e.mg/100 ml de TFSA), abtidos em diferentes profundidade do solo, referentes aos diversos tratamen tos estudados no ano agrícola 1981/1982.

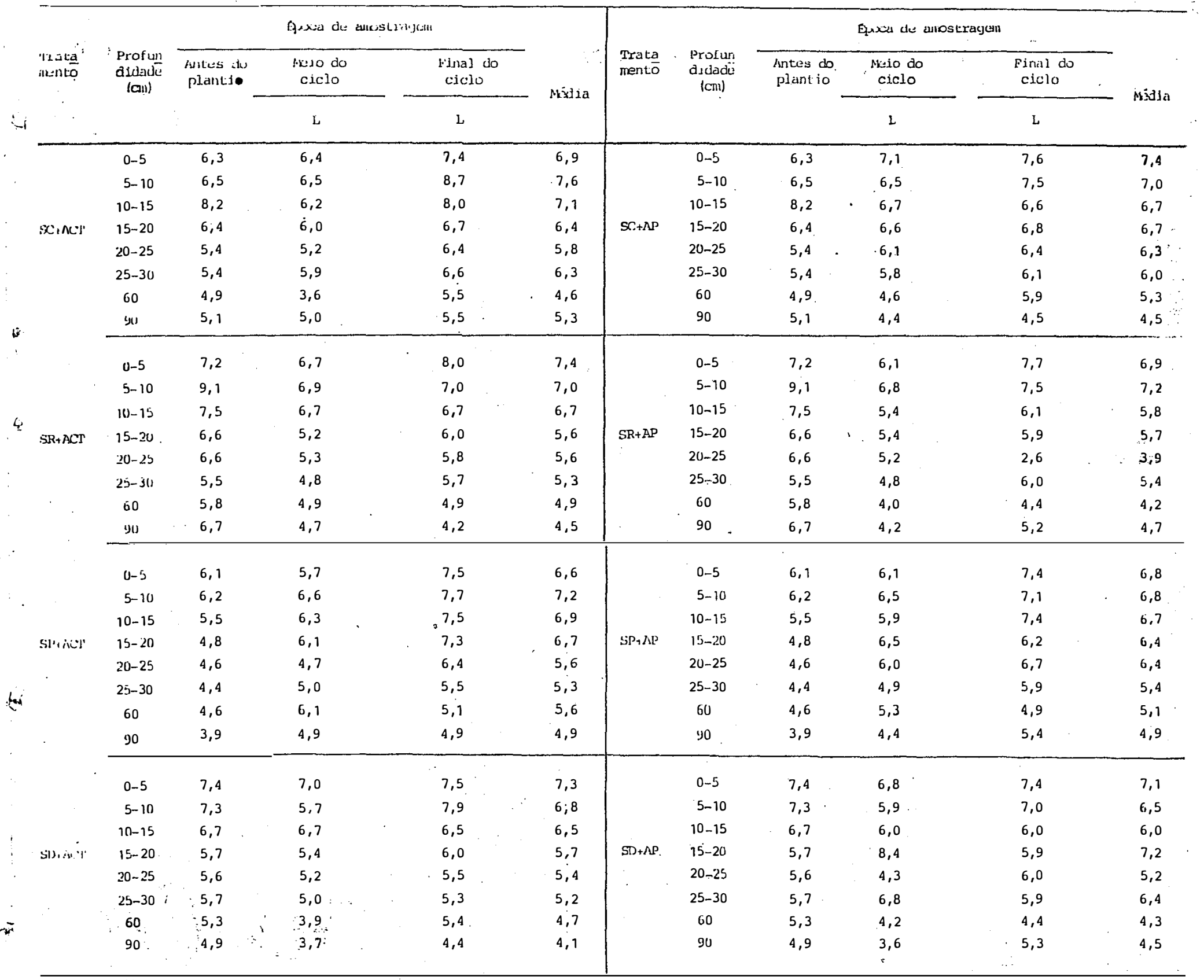


Apéndice 14 - Valores de C.T.C. ao pH 7,0 (e.mg/100ml de TFSA), obtidos em dife rentes profundidades do solo, referentes aos diversos tratamentos estudados no ano agrícola 1982/83.

\begin{tabular}{|c|c|c|c|c|c|c|c|c|c|c|c|c|c|c|c|}
\hline \multirow{3}{*}{$\begin{array}{c}\bar{\therefore} \\
\text { Trata } \\
\text { mento }\end{array}$} & \multirow{3}{*}{$\begin{array}{l}\text { Erofin } \\
\text { didade } \\
\text { (can) }\end{array}$} & \multicolumn{5}{|c|}{ 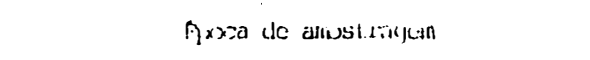 } & \multirow{3}{*}{ Mólia } & \multirow{3}{*}{ manto. } & \multirow{3}{*}{$\begin{array}{l}\text { Profiun } \\
\text { didade } \\
\text { (cn) }\end{array}$} & \multicolumn{5}{|c|}{ Exoco de anvotiagenn } & \multirow{3}{*}{$\begin{array}{c}\because \\
\ddots \\
\ddots \\
\\
\ddots\end{array}$} \\
\hline & & \multirow[t]{2}{*}{$\begin{array}{l}\text { ances do } \\
\text { plantio }\end{array}$} & \multicolumn{2}{|c|}{$\begin{array}{l}\text { Maio do } \\
\text { ciclo }\end{array}$} & \multicolumn{2}{|c|}{$\begin{array}{l}\text { Pinal do } \\
\text { ciclo }\end{array}$} & & & & \multirow[t]{2}{*}{$\begin{array}{l}\text { Antes do } \\
\text { plantio }\end{array}$} & \multicolumn{2}{|c|}{$\begin{array}{l}\text { Maio do } \\
\text { ciclo }\end{array}$} & \multicolumn{2}{|c|}{$\begin{array}{l}\text { Flnal do } \\
\text { cicio }\end{array}$} & \\
\hline & & & E & L & $E$ & L & & & & & E & L & E & I. & \\
\hline \multirow{11}{*}{$\mathrm{Sc}_{+} \mathrm{nCr}$. } & $0-5$ & 7,0 & 7,6 & 6,7 & 6,5 & 6,5 & 6,8 & \multirow{8}{*}{$S C+A P$} & $0-5$ & & 7,3 & 6,4 & 6,5 & 6,6 & 6,7 \\
\hline & $5-10$ & 6,8 & 6,9 & 7,3 & 6,6 & 6,9 & 6,9 & & $5-10$ & & 7,3 & 6,9 & 6,6 & 6,2 & 6,8 \\
\hline & $10-15$ & 6,7 & 6,7 & 5,3 & 6,0 & 7,1 & 6,3 & & $10-15$ & & 7,3 & 6,8 & $6,6^{\circ}$ & 5,8 & 6,6 \\
\hline & $15-20$ & 6,8 & 5,9 & 6,4 & 6,3 & 5,7 & 6,1 & & $15-20$ & & 5,8 & 6,2 & 6,1 & 5,9 & 6,0 \\
\hline & $20-25$ & 5,6 & 5,4 & 5,0 & 5,2 & 5,5 & 5,3 & & $20-25$ & & 5,7 & 5,2 & 5,4 & 5,2 & 5,4 \\
\hline & $25-30$ & 5,9 & 5,2 & 7,1 & 5,1 & 5,2 & 5,7 & & $25-30$ & & 5,4 & 4,3 & 5,3 & 5,6 & 5,2 \\
\hline & 60 & 4,2 & 5,9 & 4,1 & 4,8 & 4,5 & 4,8 & & 60 & & 4,7 & 5,7 & 4,8 & 4,5 & 4,9 \\
\hline & 90 & 4,3 & 4,1 & 3,5 & 3,9 & 4,4 & 4,0 & & 90 & & 4,5 & 4,3 & 4,7 & $\dot{4}, 7$ & 4,6 \\
\hline & $0-5$ & 8,8 & 7,0 & 8,3 & 7,1 & 8,7 & 7,8 & \multirow{8}{*}{$\mathrm{SR}+\mathrm{AP}$} & $0-5$ & \multirow{8}{*}{. } & 6,2 & 7,2 & 7,3 & 8,3 & \multirow{3}{*}{$\begin{array}{l}7,3 \\
7,2 \\
5,8,8\end{array}$} \\
\hline & $5-10$ & 8,6 & 7,9 & 7,7 & 7,8 & 8,3 & 7,9 & & $5-10$ & & \multirow{2}{*}{$\begin{array}{l}6,7 \\
5 ; 6\end{array}$} & \multirow{2}{*}{$\begin{array}{l}6,7 \\
6,1^{1}\end{array}$} & \multirow{2}{*}{$\begin{array}{l}7,5 \\
5 ; 3\end{array}$} & \multirow{2}{*}{$\begin{array}{l}8,0 \\
5 ; 2\end{array}$} & \\
\hline & $10-15$ & 7,4 & 7,2 & 6,4 & 7,4 & 7,4 & 7,1 & & $10-15$ & & & & & & \\
\hline \multirow{8}{*}{$\begin{array}{r}\mathrm{SR}+\mathrm{ACT} \\
\vdots \\
4 \\
4\end{array}$} & $15-20$ & 6,5 & 4,7 & 5,6 & 6,1 & 6,3 & 5,7 & & $15-20$ & & 6,5 & 5,5 & 5,8 & 6,4 & 6,1 \\
\hline & $20-25$ & 8,4 & 5,6 & 6,2 & 4,9 & 6,0 & 5,7 & & $20-25$ & & 4,7 & 5,0 & 5,3 & 5,6 & 5,2 \\
\hline & $25-30$ & 7,1 & 4,9 & $6, ?$ & 5,7 & 5,8 & 5,8 & & $25-30$ & & 4,0 & 5,4 & 6,1 & 5,1 & 5,2 \\
\hline & 60 & 5,8 & 5,4 & 3,5 & 5,5 & 4,6 & 4,8 & & 60 & & 3,8 & 5,1 & 5,0 & 4,2 & 4,5 \\
\hline & 30 & 5,1 & 3,2 & 5,0 & 5,3 & 5,5 & 4,8 & & 90 & & 4,4 & 3,5 & 5,0 & 4,4 & 4,3 \\
\hline & $0-5$ & 7,1 & 6,1 & 7,1 & 7,1 & 6,6 & 6,7 & & $0-5$ & & 6,3 & 7,2 & 6,5 & 7,3 & 6,8 \\
\hline & $5-10$ & 6,4 & 6,5 & 8,2 & 3,1 & 6,8 & 7,2 & & $5-10$ & & 6,6 & 6,9 & 6,7 & 7,0 & 6,8 \\
\hline & $10-15$ & 6,4 & 7,4 & 6,7 & 6,0 & 6,8 & 6,7 & & $10-15$ & . & 6,7 & 6,4 & 6,6 & $6, \grave{5}$ & 6,6 \\
\hline $\mathrm{SP}^{\prime}+\mathrm{ACT}$ & $15-20$ & 5,6 & 5,7 & 5,3 & 5,4 & 6,5 & 5,7 & $\mathrm{~S} \Gamma+/ \mathrm{P}$ & $15-20$ & & 6,4 & 7,1 & 6,1 & 7,0 & 6,7 \\
\hline & $20-25$ & 5,0 & 4,4 & 4,8 & 5,5 & 6,4 & 5,3 & & $20-25$ & & 4,5 & 5,6 & 5,0 & $6,0$. & 5,3 \\
\hline & $25-30$ & 4,6 & 5,2 & 5,9 & 5,4 & 5,3 & 5,5 & & $25-30$ & & 4,9 & 5,0 & 5,0 & 5,5 & 5,1 \\
\hline & 60 & 4,6 & 5,0 & 3,8 & 5,2 & 5,0 & 4,8 & & 60 & & 3,7 & 4,0 & 4,0 & 4,5 & 4,1 \\
\hline & 90 & 4,3 & 4,0 & 4,3 & 5,7 & 5,2 & 4,8 & . & 90 & & 3,9 & 4,0 & 4,1 & 4,3 & 4,1 \\
\hline & $0-5$ & 8,2 & 7,0 & 6,2 & 8,1 & 7,3 & 7,2 & & $0-5$ & & 8,0 & 6,3 & 7,1 & 7,2 & 7,2 \\
\hline & $5-10$ & 5,5 & 5,9 & 5,3 & 6,9 & 7,1 & 6,3 & & $5-10$ & & 7,0 & 7,2 & 6,1 & 6,4 & 6,7 \\
\hline & $10-15$ & 6,6 & 4,8 & 4,9 & 7,5 & 6,1 & 5,8 & & ' $10-15$ & . & 5,6 & 4,9 & 6,6 & 6,1 & 5,8 \\
\hline$S D+A C P$ & $15-20$ & 6,2 & 4,4 & 3,6 & 6,5 & 4,9 & 4,9 & $\mathrm{SD}+\mathrm{AP}$ & $15-20$ & & 5,1 & 4,5 & 5,4 & 6,6 & 5,4 \\
\hline & $20-25$ & 5,8 & 4,2 & 4,5 & 5,8 & 4,5 & 4,8 & & $20-25$ & & 3,8 & 4,5 & 5,1 & 4,2 & 4,4 \\
\hline 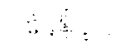 & $25-30$ & 5,9 & 3,9 & 3,2 & 5,0 & 5,1 & 4,3 & & $25-30$ & & 5,2 & 4,6 & 4,5 & 4,8 & 4,8 \\
\hline & 60 & 5,4 & 3,4 & 3,9 & 3,3 & 5,2 & 4,0 & & 60 & & 3,6 & 3,9 & 4,5 & 4,2 & 4,1 \\
\hline o & 90 & 4,8 & 4,1 & 2,9 & 4,8 & 4,5 & 4,1 & & 90 & & 3,9 & 4,2 & 4,7 & 3,6 & 4,1 \\
\hline
\end{tabular}

$\mathrm{E}=$ entrelinhá

$L=1$ linha 
Apéndice 15 - Valores de alumínio trocável (e.mg/100 ml de TFSA) e saturação de alumínio (\%), obtidos em diferentes profundidades do solo, referentes aos diversos tratamentos estudados no ano agrícola 1981/82.

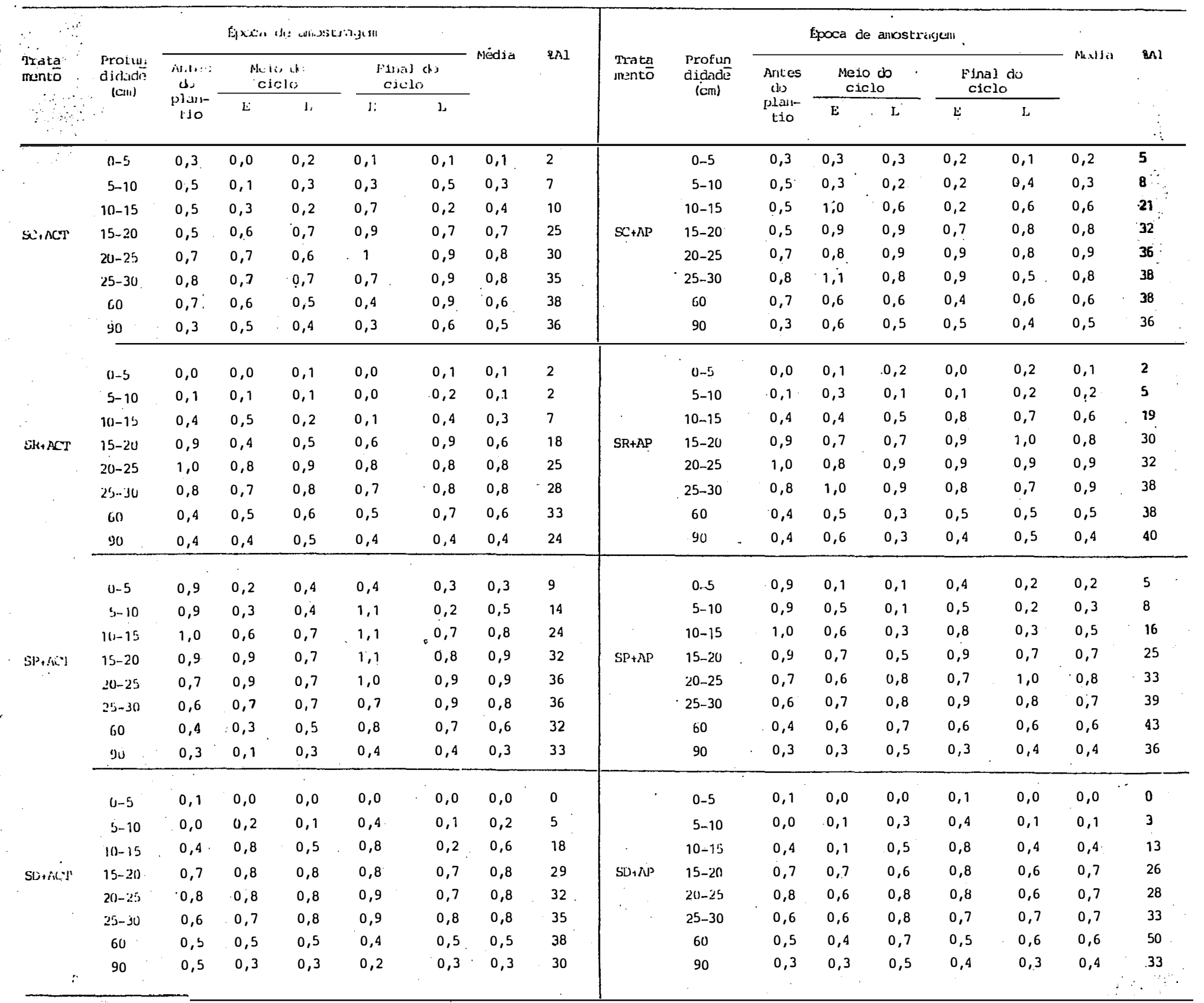

\footnotetext{
'E entrelinhia
} 
Apêndice 16 - Valores de alumínio trocável (e.mg/100 ml de TFSA) e saturação de aluminio (\%), obtidos em diferentes profundidades do solo, referentes aos diversos tratamentos estudados no ano agrícola 1982/83.

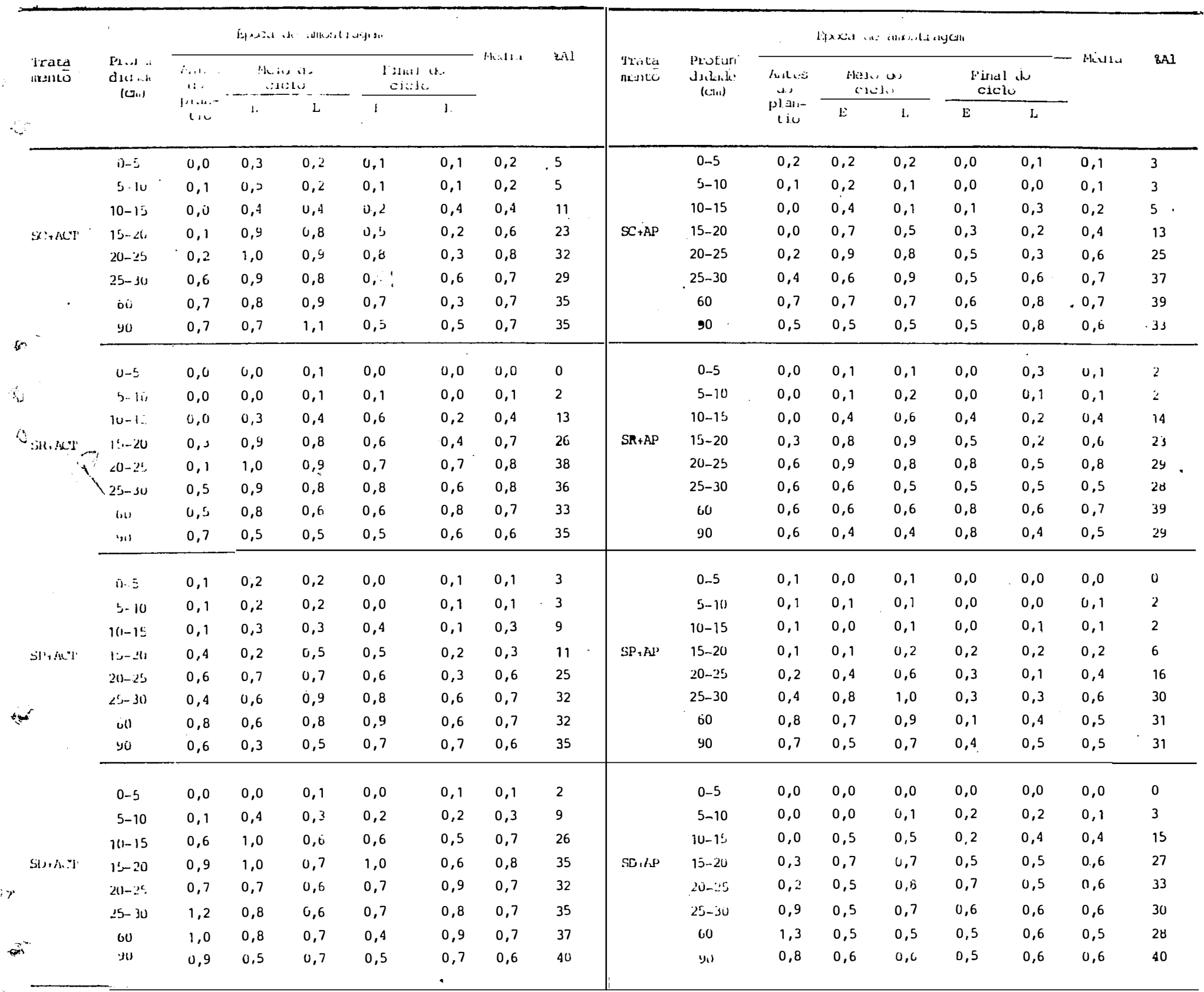

-. $\quad E=4 i l s c 111 d$ dics

5. $1 .=1$ inula 
.119.

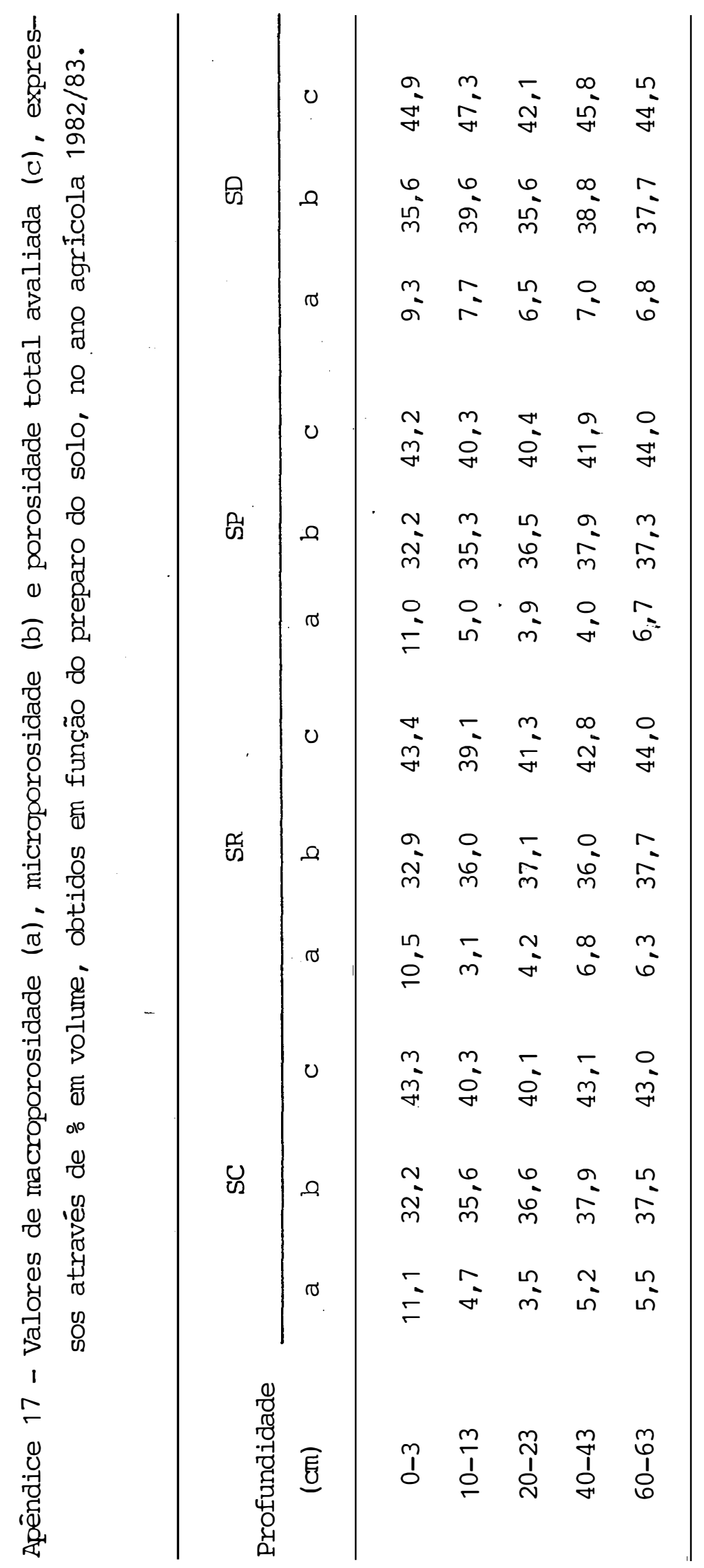


.120 .

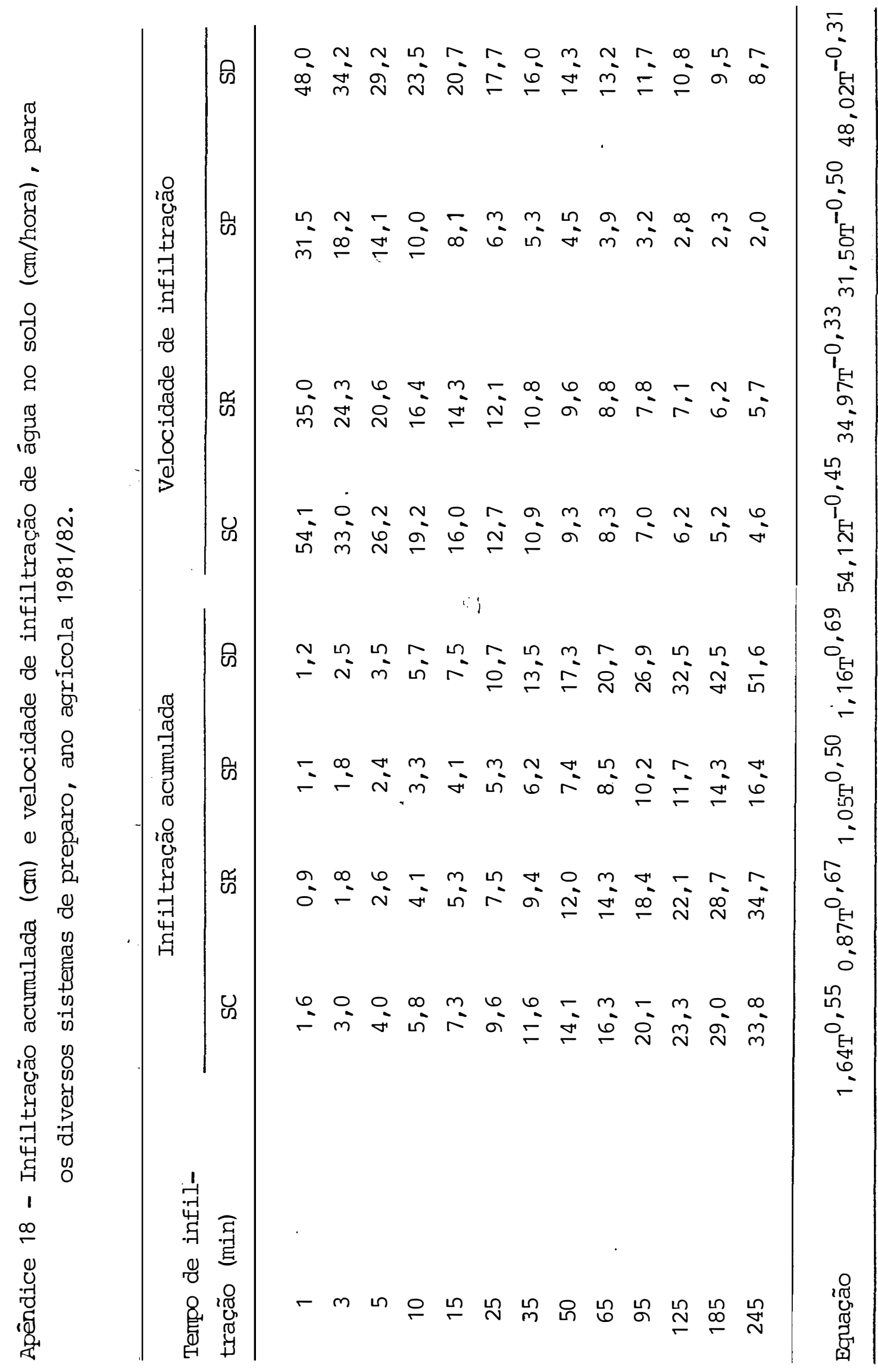




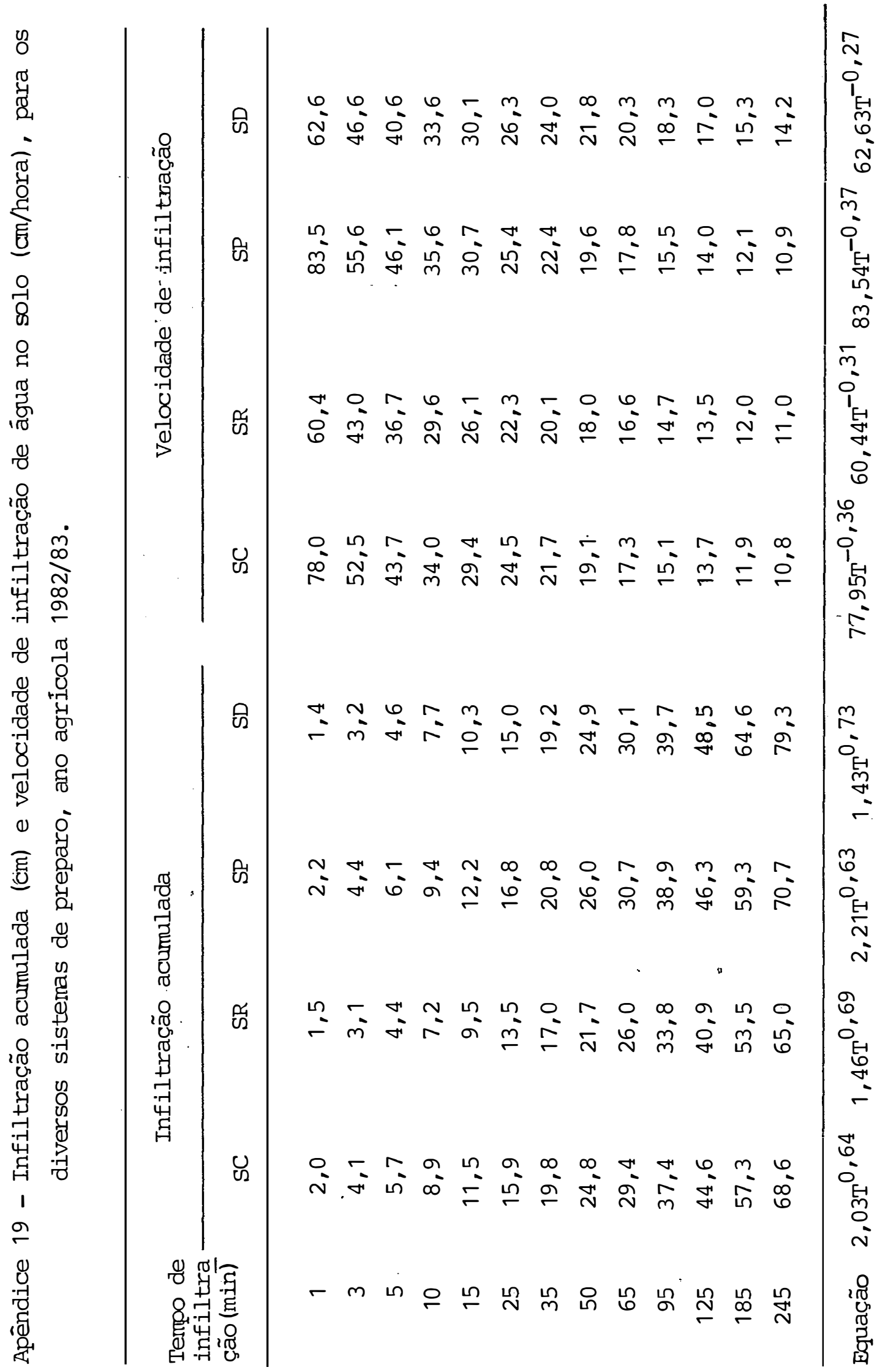




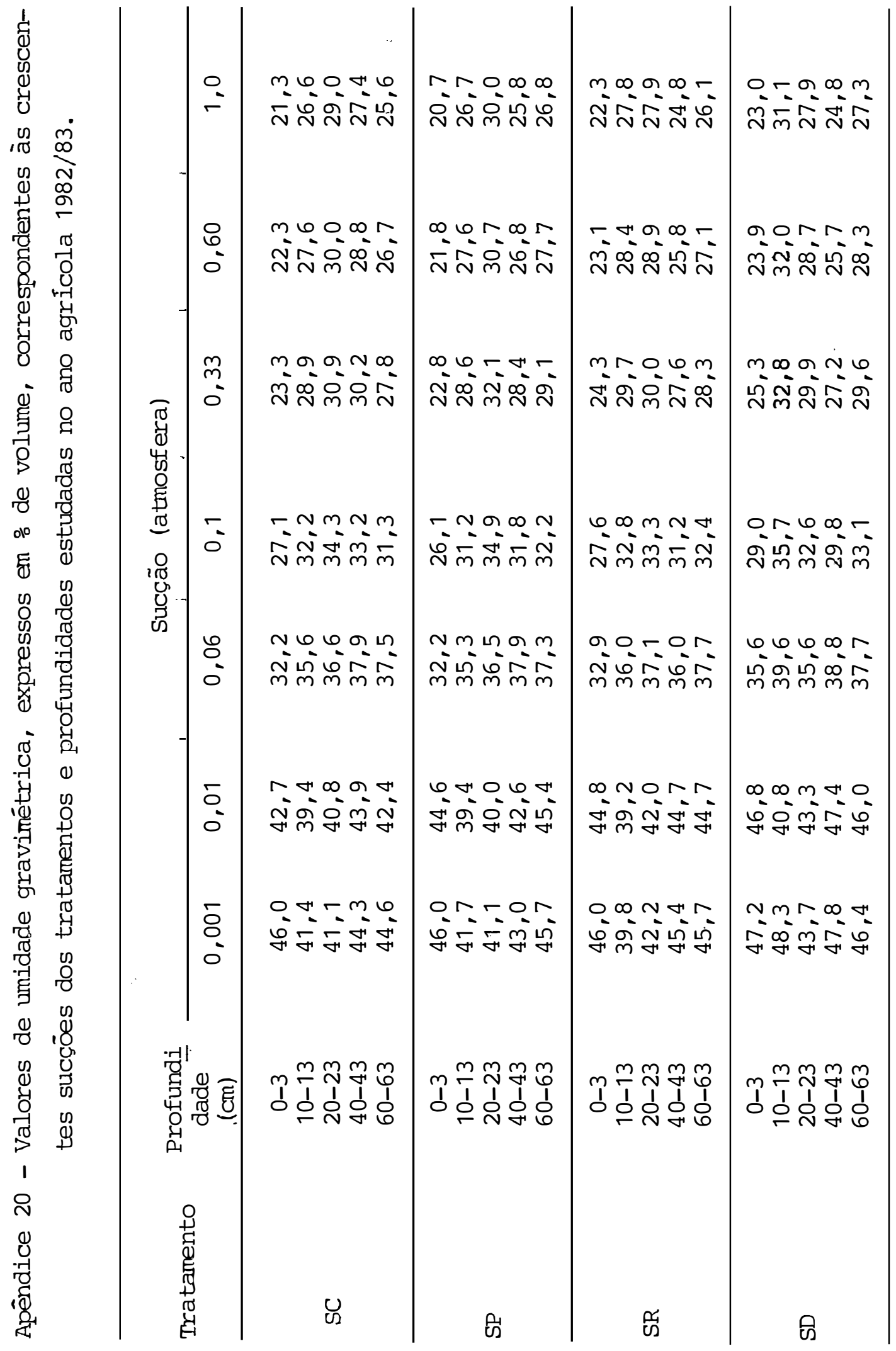




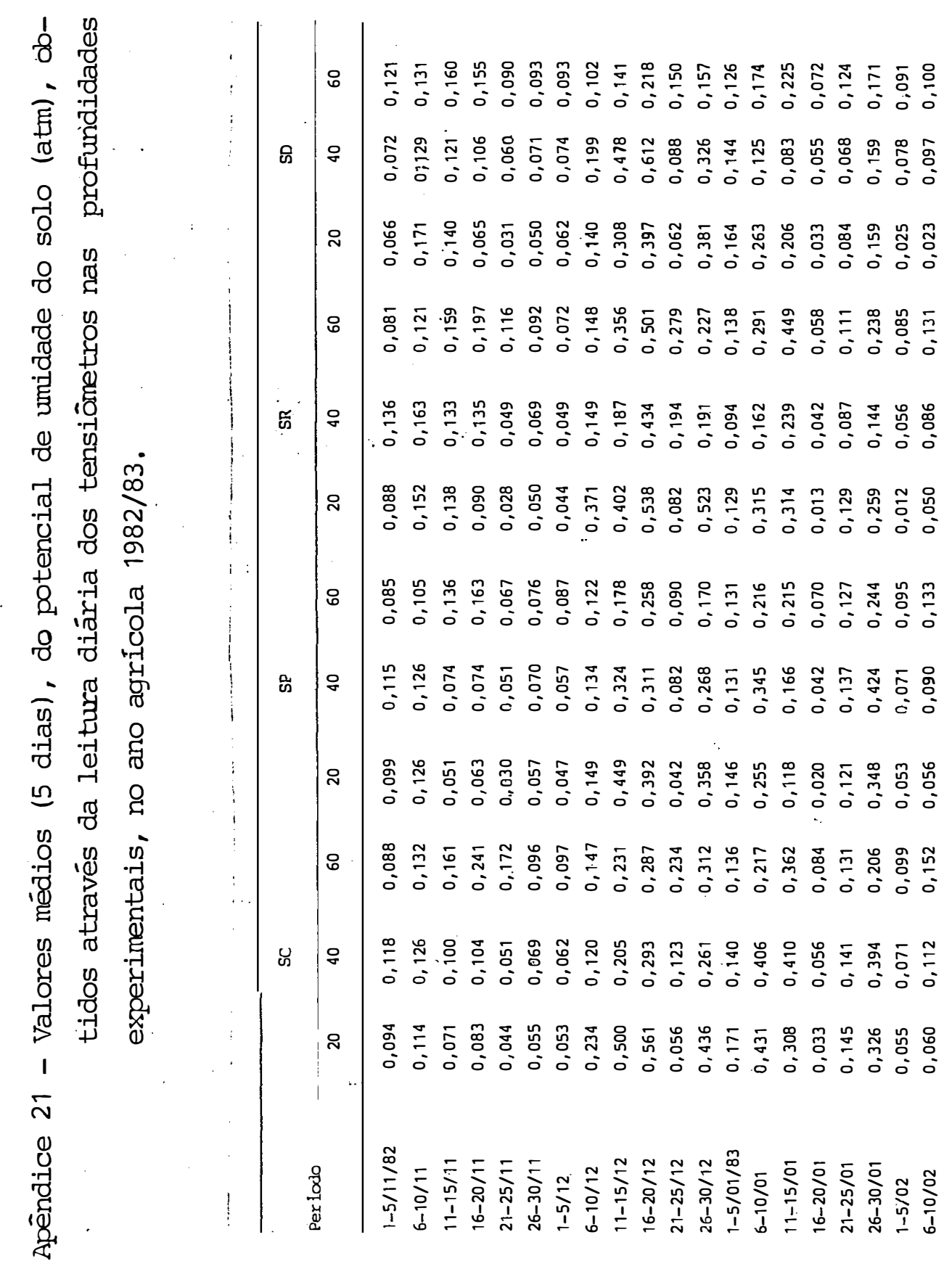




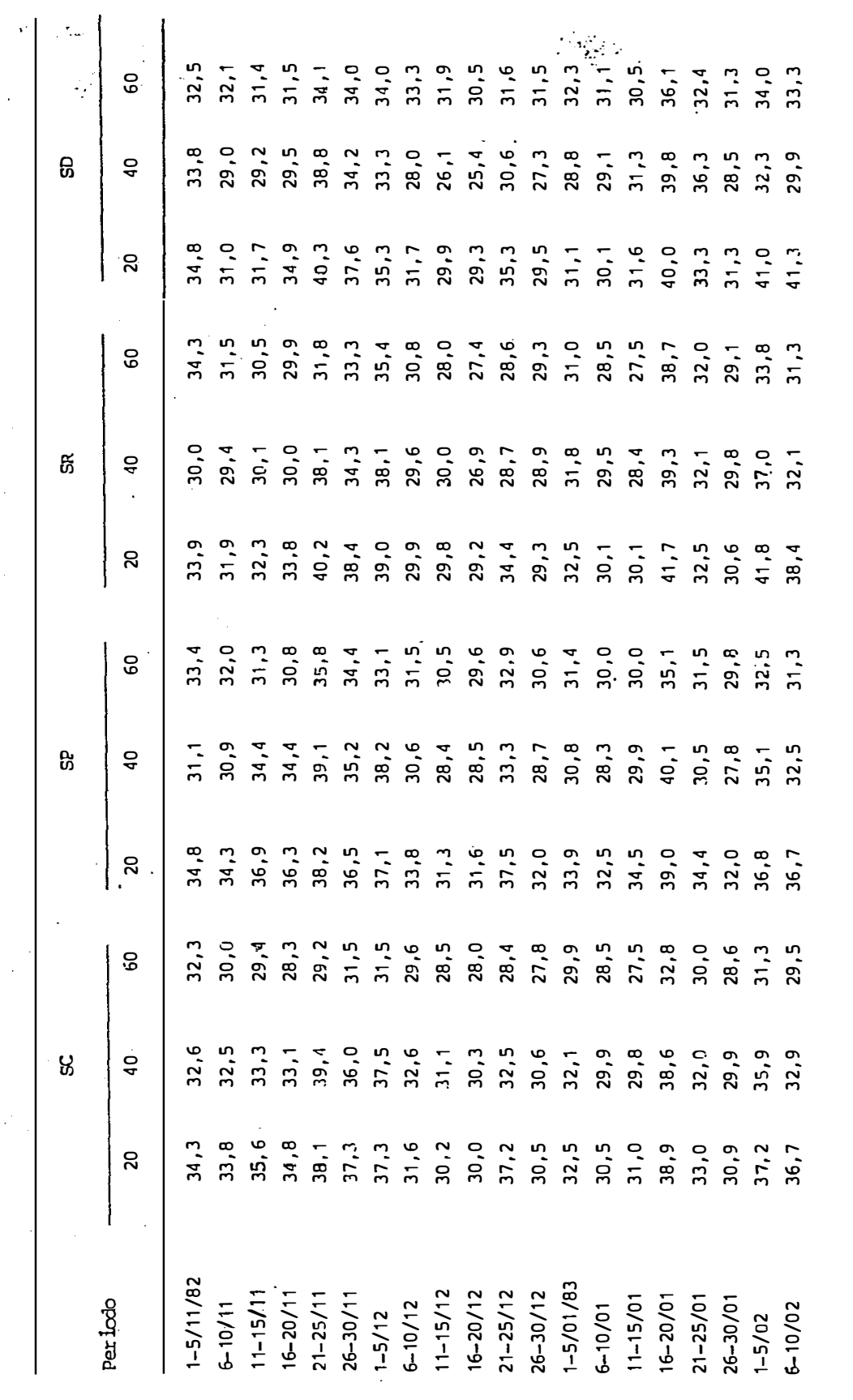

